GROUND-WATER FLOW AND QUALITY BENEATH SEWAGE-SLUDGE LAGOONS,

AND A COMPARISON WITH THE GROUND-WATER QUALITY BENEATH A

SLUDGE-AMENDED LANDFILL, MARION COUNTY, INDIANA

By Keith E. Bobay

U.S. GEOLOGICAL SURVEY

Water-Resources Investigations Report 88-4175

Prepared in cooperation with the

INDIANAPOLIS DEPARTMENT OF PUBLIC WORKS

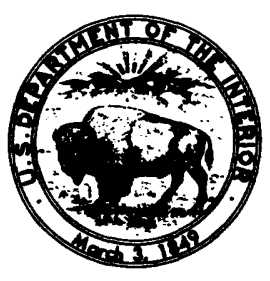

Indianapolis, Indiana 
DEPARTMENT OF THE INTERIOR

DONALD PAUL HODEL, Secretary

U.S. GEOLOGICAL SURVEY

Dallas L. Peck, Director

For additional information, write to:

District Chief

U.S. Geological Survey

5957 Lakeside Boulevard

Indianapolis, IN 46278-1996
Copies of this report

can be purchased from:

U.S. Geological Survey Books and Open-File Reports Federal Center, Building 810 Box 25425

Denver, CO 80225-0425 


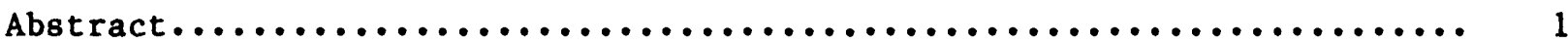

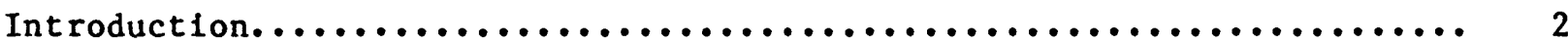

Purpose and scope.................................... 4

Previous studies..................................... 4

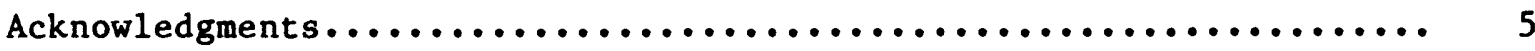

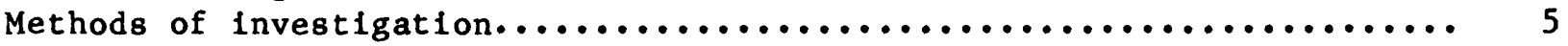

Observation-well installation and sampling procedures........... 7

Quality-assurance and quality-control program................. 9

Statistical analysis................................. 13

Description of the study area................................ 16

Belmont advanced wastewater-treatment plant and sewage-sludge

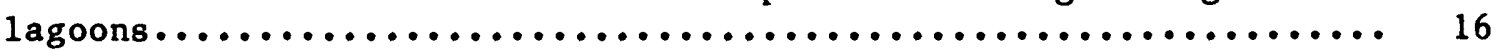

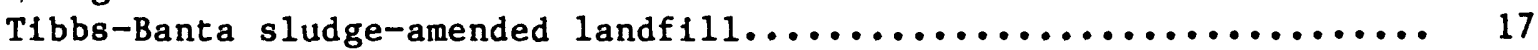

Characteristics of sewage sludge........................... 19

Hydrogeologic setting.................................. 21

Flow of ground water beneath the Belmont sewage-sludge lagoons......... 28

Quality of ground water beneath the Belmont sewage-sludge lagoons...... 37

Factors that affect the migration of leachate in ground water..... 39

Water-quality constituents........................... 41

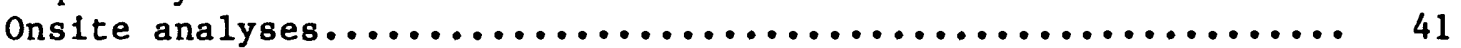

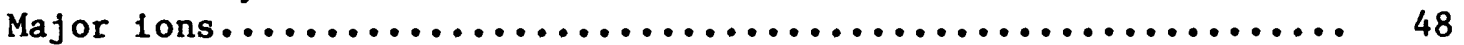

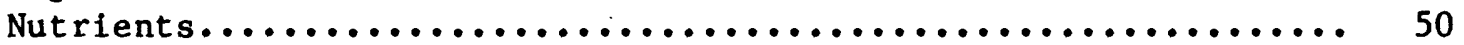

Metals and trace elements........................... 53

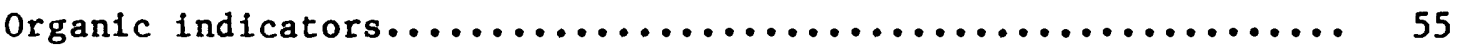

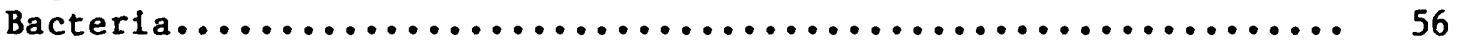

Changes in ground-water quality with time and depth............ 57

Quality of ground water beneath the Tibbs-Banta sludge-amended landfill. 59

General characteristics of landfill leachate................. 59

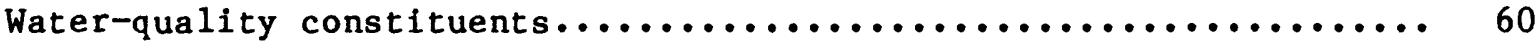

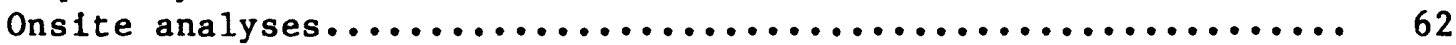

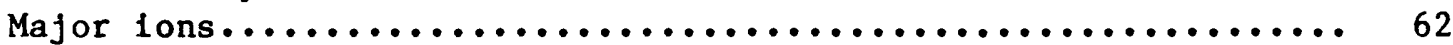

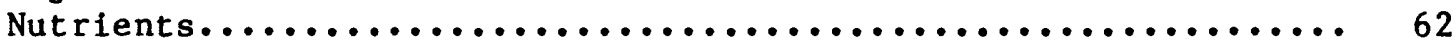

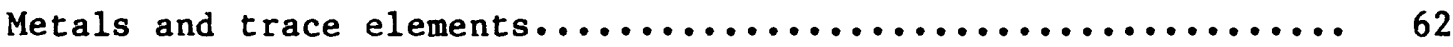

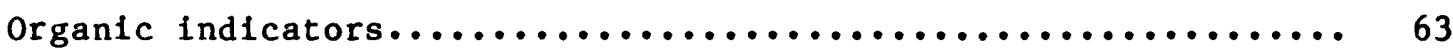

Comparison of ground-water quality beneath the Belmont sewage-sludge

lagoons and the Tibbs-Banta sludge-amended landf $111 \ldots \ldots \ldots \ldots \ldots \ldots \ldots$

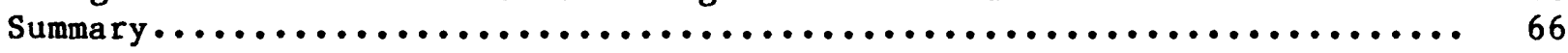

References clted........................................ 69 


\section{FIGURES}

Page

Figures 1-4. Maps showing:

1. Location of study area......................... 3

2. Belmont wastewater-treatment plant sewage-sludge lagoons and location of observation wells......... 6

3. Tibbs-Banta sludge-amended landfill and location of

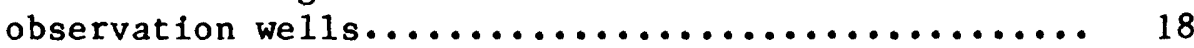

4. Surficial geology of Marion County............... 22

5. Geologic section showing generalized lithology beneath the

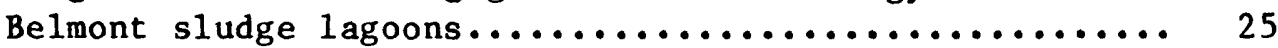

6. Fence diagram showing generalized lithology and location

of well screens beneath the Belmont sludge lagoons......

7. Geologic section showing generalized 1ithology beneath the

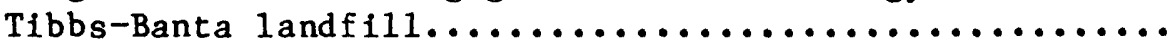

8a-9b. Diagrams showing:

8a. Altitude of the water table and general direction of shallow ground-water flow beneath the Belmont sludge

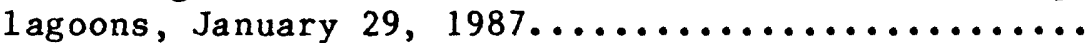

8b. Altitude of the water table and reversed direction of shallow ground-water flow beneath the Belmont sludge

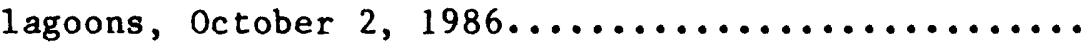

9a. Altitude of the water table and general direction of deep ground-water flow beneath the Belmont sludge lagoons, January 29, $1987 \ldots \ldots \ldots \ldots \ldots \ldots \ldots \ldots \ldots$

9b. Altitude of the water table and reversed direction of deep ground-water flow beneath the Belmont sludge

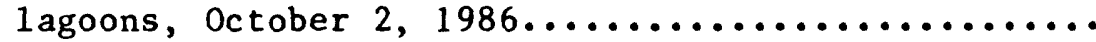
3 6

10-13. Hydrographs showing:

10. Altitude of water surface near Belmont well sites A and $B$, and daily precipitation, June 1986 through

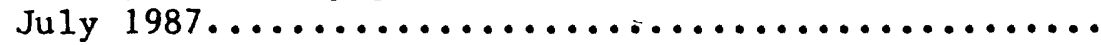

11. Altitude of water surface near Belmont well sites $C$ and $D$, and daily precipitation, June 1986 through

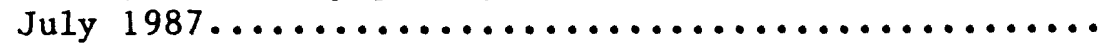

12. Altitude of water surface near Belmont well sites $E$ and F, and daily precipitation, June 1986 through July $1987 \ldots \ldots \ldots \ldots \ldots \ldots \ldots \ldots \ldots \ldots \ldots \ldots \ldots \ldots \ldots \ldots \ldots$

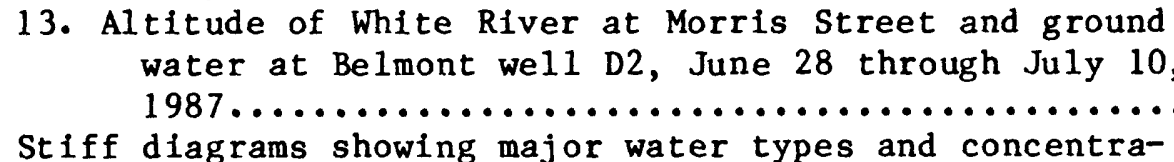

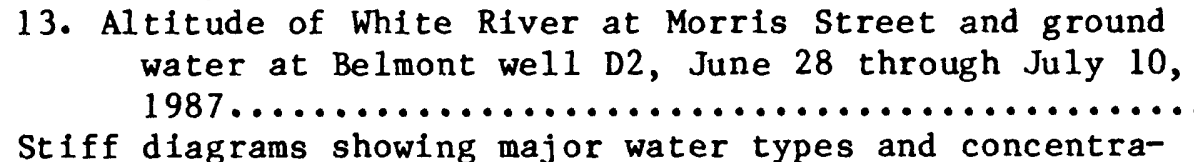

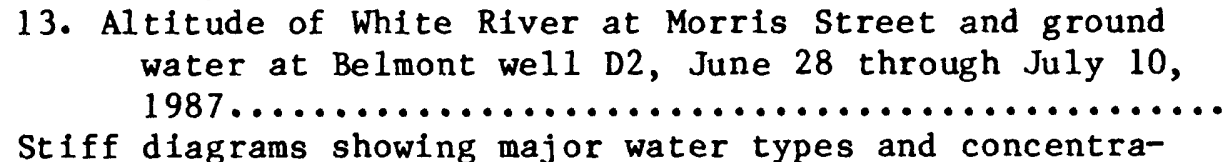
tions of dissolved solids in the ground water beneath the Belmont sludge lagoons, May $1987 . \ldots \ldots \ldots \ldots \ldots \ldots \ldots$ 


\section{TABLES}

Page

Table 1. Description of observation wells at the Belmont sewage-sludge

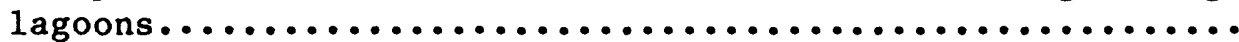

2. Results of the analysis of blank samples by the Indianapolis Department of Public Works and the U.S. Geological Survey laboratories. ..........................................

3. Summary of results from the Wilcoxon signed-rank test to determine differences in duplicate samples...............

4. Results of the Standard Reference Water Sample qualityassurance program for the Indianapolis Department of Public

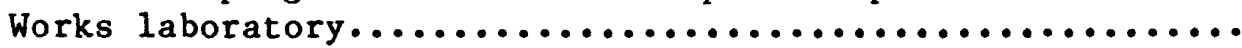

5. Statistical summary of municipal sewage-sludge

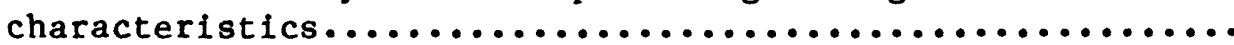

6. Summary of ground-water and surface-water levels near the Belmont sludge lagoons, June 1986 through July 1987........

7. Statistical summary of ground-water-quality data from the Marion County sand and gravel outwash aquifer, and U.S. Environmental Protection Agency secondary drinking-water

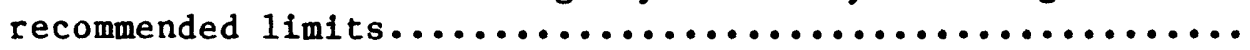

8. Statistical summary of ground-water-quality data from the shallow aquifer beneath the Belmont sludge lagoons, July

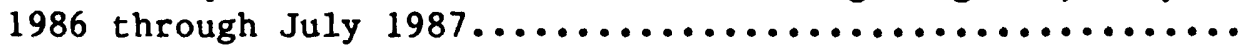

9. Statistical summary of ground-water-quality data from the deep aquifer beneath the Belmont sludge lagoons, July 1986

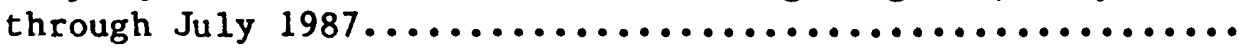

10. Summary of results from analysis of variance on ranks to determine differences in selected ground-water constituents between shallow and deep aquifers beneath the Belmont

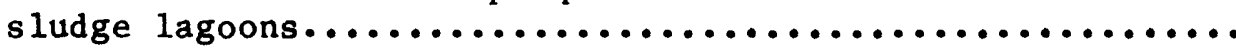

11. Statistical summary of ground-water-quality data downgradient from the Tibbs-Banta landfill, May 1985 through May 1986...

12. Summary of results from analysis of variance on ranks to determine differences in selected ground-water constituents by aquifer (shallow or deep) between the Belmont sludge lagoons and the Tibbs-Banta sludge-amended landfill........ 


\section{CONVERSION FACTORS}

Inch-pound units in this report may be converted to metric (International System) units by using the following conversion factors:

Multiply inch-pound units

acre-foot (acre/ft)

cubic foot per second $\left(\mathrm{ft}^{3} / \mathrm{s}\right)$

cublc foot per second per mile

$$
\text { [ } \left.\left(\mathrm{ft}^{3} / \mathrm{s}\right) / \mathrm{mi}\right]
$$

cubic yard $\left(\mathrm{yd}^{3}\right)$

foot ( $f t$ )

foot per day ( $f t / d)$

foot squared per day $\left(f t^{2} / d\right)$

gallon per day (gal/d)

gallon per day per square mile

$$
\text { [(gal/d)/mi } \left.{ }^{2}\right]
$$

gallon per minute (gal/min)

Inch (in.)

inch per year (in/yr)

mile (mi)

miliion gallons per day ( $\mathrm{Mgal} / \mathrm{d}$ )

pound, avoirdupois (1b)

pound per acre ( $1 \mathrm{~b} / \mathrm{acre}$ )

square foot $\left(f t^{2}\right)$

square mile $\left(\mathrm{mi}^{2}\right)$

ton, short
By

1,233

0.028317

0.017599

0.76455

0.3048

0.3048

0.0929

3.785

0.001460

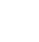

0.06308

25.4

2.54

1.609

0.04381

4.536

0.001121

0.09294

2.590

0.9072
To obtain metric units

cubic meter $\left(\mathrm{m}^{3}\right)$

cubic meter per second $\left(\mathrm{m}^{3} / \mathrm{s}\right)$

cubic meter per second per

kilometer $\left[\left(\mathrm{m}^{3} / \mathrm{s}\right) / \mathrm{km}\right]$

cubic meter $\left(\mathrm{m}^{3}\right)$

meter (m)

meter per day (m/d)

meter squared per day $\left(\mathrm{m}^{2} / \mathrm{d}\right)$

liter per day ( $\mathrm{L} / \mathrm{d})$

cubic meter per day per square kilometer $\left[\left(\mathrm{m}^{3} / \mathrm{d}\right) / \mathrm{km}^{2}\right]$

liter per second $(\mathrm{L} / \mathrm{s})$

millimeter (mm)

centimeter per year $(\mathrm{cm} / \mathrm{yr})$

kilometer ( $\mathrm{km})$

cubic meter per second $\left(\mathrm{m}^{3} / \mathrm{s}\right)$

kilogram (kg)

kilogram per square meter

$$
\left(\mathrm{kg} / \mathrm{m}^{2}\right)
$$

square meter $\left(\mathrm{m}^{2}\right)$

square kilometer $\left(\mathrm{km}^{2}\right)$

megagram ( $\mathrm{Mg})$

Temperature in degrees Fahrenhelt $\left({ }^{\circ} \mathrm{F}\right)$ can be converted to degrees Celsius $\left({ }^{\circ} \mathrm{C}\right)$ as follows:

$$
{ }^{\circ} \mathrm{C}=5 / 9\left({ }^{\circ} \mathrm{F}-32\right)
$$

Sea Leve1.--In this report "sea level" refers to the National Geodetic Vertical Datum of 1929 (NGVD of 1929)--a geodetic datum derived from a general adjustment of the first-order level nets of the United States and Canada, formerly called "Sea Level Datum of 1929." 


\title{
GROUND-WATER FLOW AND QUALITY BENEATH SEWAGE-SLUDGE LAGOONS, \\ AND A COMPARISON WITH THE GROUND-WATER QUALITY BENEATH A \\ SLUDGE-AMENDED LANDFILL, MARION COUNTY, INDIANA
}

\author{
By Keith E. Bobay
}

\section{ABSTRACT}

The ground water beneath elght sewage-sludge lagoons was studied to characterize the flow regime and to determine whether leachate had infiltrated into the glaciofluvial sediments. In addition, ground-water quality beneath the lagoons was compared with the ground-water quality beneath a closed, municipal landfill where sludge had been incorporated into the surface soil. The lagoons and the landfill overlie outwash sand and gravel deposits separated by discontinuous clay layers in the White River valley. The sand and gravel deposits form a shallow aquifer to a depth of approximately 50 feet below the surface. The deep aquifer generally extends to 110 feet below the surface.

Ground water in the shallow aquifer beneath the sludge lagoons generally flows semiradially away from the lagoons and parallel to Eagle Creek at approximately 0.12 to 0.29 feet per day, eventually discharging to the white River. Water in the deep aquifer also flows semiradially away from the lagoons at approximately 0.10 to 0.24 feet per day; some water discharges to the White River and some flows to the south and west beneath Eagle Creek. After an accumulation of approximately 2 inches of precipitation during 1 week or less, water from both streams recharge the shallow aquifer until the water level of the White River recedes below the ground-water levels. Simllarly, in the deep aquifer, recharge from the White River temporarily reverses the ground-water gradient away from the river.

Ground water beneath the lagoons can be characterized as pH neutral, nearly anaerobic, and having moderate to high specific conductance (879 to 2,560 microsiemens per centimeter at 25 degrees Celsius). Concentrations of most major lons, iron, and manganese exceed long-term concentrations for the outwash sand and gravel aquifer in Marion County. The ground water beneath the lagoons is predominantly a calcium bicarbonate type, although ammonium accounts for more than 30 percent of the total cations in water from two deep wells and one shallow well adjacent to the lagoons. Arsenic is present at concentrations that exceed 50 micrograms per liter in water from two shallow wells. Barium is present at concentrations that exceed 1 milligram per liter in water from one deep well. In addition, concentrations of sodium, chloride, sulfate, iron, boron, chemical oxygen demand, dissolved solids, and methyleneblue-active substances indicate the presence of leachate from the lagoons in the ground water. The stability of the sludge and the presence of neutral pH and reducing conditions result in extremely low or undetectable concentrations of cadmium, chromium, copper, lead, mercury, nickel, selenium, and zinc. 
There was no statistically significant difference at the 0.05 level between the five sampling dates at the Belmont lagoons for 17 of the 24 constituents tested--that is, concentrations of most constituents do not change seasonally. Fifteen of the constituents had statistically significant higher concentrations in the shallow aquifer compared to the deep aquifer. Only $\mathrm{pH}$ and barium concentrations were significantly higher in water from the deep aquifer compared to the shallow aquifer.

Nineteen constituents or physical properties common to the water-quality data from the lagoons and the landfill were used to compare the quality of shallow and deep ground water at both sites. Statistical analysis indicated that 16 constituents had significantly different (at the 0.05 probability level) concentrations between the two sites. Concentrations of sodium, potassium, total alkalinity, chloride, dissolved solids, arsenic, iron, nitrate nitrogen, ammonium nitrogen, total phosphorus, and chemical oxygen demand were higher in the shallow aquifer beneath the sludge lagoons compared to the sha1low aquifer beneath the landfill. Only concentrations of dissolved oxygen and bromide were higher in water from the shallow aquifer beneath the landfill. Similarly, water in the deep aquifer had concentrations of magnesium, potassium, total alkalinity, chloride, sulfate, iron, and ammonium nitrogen that were higher at the sludge lagoons than at the landf111. Only pH, in water from the deep aquifer, was higher at the landfill than at the lagoons.

\section{INTRODUCTION}

The City of Indianapolis, Department of Public Works (IDPW), operates two advanced wastewater-treatment (AWT) plants in Marion County, Indiana (fig. 1 ). The residual solids, or sludge, generated at the plants currently (1988) are incinerated at the Belmont plant. However, during the past 30 yr (years), excess sludge has been stored in lagoons at the Belmont plant and, more recently, at the Southport plant. In 1981 and 1983, the IDPW began applying sludge from the lagoons onto the surface of two closed, municipal landfills, Julietta and Tibbs-Banta ( $\mathrm{fig} .1$ ). Although contaminants in the sludge have the greatest potential for movement where large quantities have been deposited for a long time (Emmerich and others, 1982, p. 174; Preul, 1968, p. 664), it was uncertain whether the storage of sludge had affected the quality of the ground water beneath the lagoons, or whether the quality of ground water beneath the lagoons differed from the quality of ground water beneath the sludge-amended landfills.

This report was prepared by the U.S. Geological Survey, Water Resources Division, in cooperation with the City of Indianapolis, Department of Public Works. 


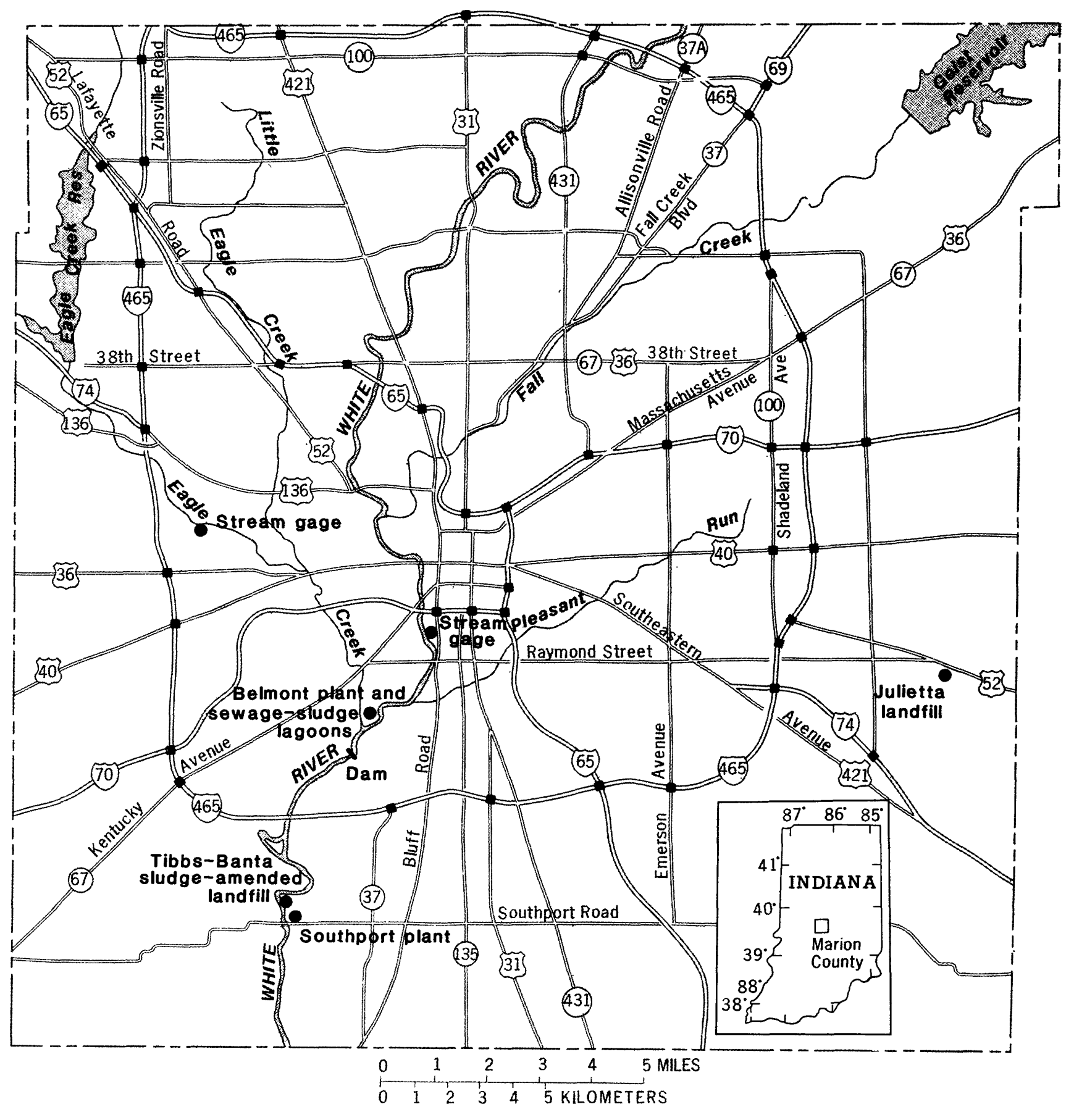

Figure 1.- Location of study area. (Modified from Pettijohn, 1977). 


\section{Purpose and Scope}

This report ( 1 ) describes the general direction and estimates the velocity of ground-water flow beneath eight Belmont sludge lagoons, (2) characterizes the ground-water quality beneath the Belmont sludge lagoons, and (3) compares the quality of ground water beneath the sludge lagoons with the quality of ground water beneath the Tibbs-Banta landfill where sludge has been incorporated into the surface soll.

Monthly ground-water and surface-water levels of the adjacent streams were measured from June 1986 through July 1987. The ground water beneath the sludge lagoons was sampled quarterly from July 1986 through July 1987 and analyzed for major ions, nutrients, metals, trace elements, organic indicators, and bacteria. Data collected by Duwelius and Greeman (in press) in a separate U.S. Geological Survey study of the Tibbs-Banta landfill in 1985 and 1986 were used to compare the quality of ground water beneath the sludge lagoons and the sludge-amended landfill.

A number of nonparametric statistical techniques were used to detect differences in constituent concentrations. The Wilcoxon signed-rank test was used to detect differences in the quality-control duplicate samples. An analysis of variance (ANOVA) was used to determine differences in concentrations over time and differences between the shallow and deep aquifers. The Wilcoxon-Mann-Whitney rank-sum test also was used to detect differences between the shallow and deep aquifers beneath the lagoons for concentrations of certain constituents. A nested ANOVA was used to determine the significance of differences between the quality of ground water in the shallow and deep aquifers beneath the lagoons, and differences between the quality of ground water beneath the lagoons and the landfill.

\section{Previous Studies}

Research on ground-water quality effects from the storage and disposal of municipal sewage sludge has not been extensive. To date (1988), most studies report the effects of liquid and semiliquid sludge applied to agricultural soils. No studies have been found that report the effects of sewage-sludge lagoons on the quality of ground water. Laboratory results characterizing leachate from the codisposal of sewage and landfill refuse recently have been presented by Farre11 and others (1987).

Duwelius and Greeman (in press) sampled the ground water beneath two sludge-amended, closed landfills in Marion County during 1985 and 1986 (TibbsBanta and Julietta). Sludge from the Indianapolis wastewater-treatment plants was incorporated into the surface layer of the Tibbs-Banta landfill in 1983 and 1984. Data from the Tibbs-Banta landfill were used in the current study for comparison with the quality of ground water beneath the Belmont lagoons because the landfill and lagoons were constructed on alluvial sediments in similar hydrogeologic settings adjacent to the White River. 
Pettijohn (1977) reported general ground-water quality and leachate movement beneath seven landfills in Marion County, including the Tibbs-Banta landf111. Leachate was detected in the shallow aquifers beneath all seven landfills; leachate from two landfills also was present in the deep aquifers. Ground water beneath five of the landfills, including Tibbs-Banta, was discharging to nearby surface waters. R. A. Pettijohn (U.S. Geological Survey, written commun., 1978) also installed two pairs of ground-water observation we11s screened beneath the sludge lagoons in the current study area. He described the local ground-water flow and the lithology beneath the lagoons.

Several authors (Meyer and others, 1975; Herring, 1976; Smith, 1983) have studied the hydrogeologic properties of the aquifers and the general occurrence, availability, and quality of ground water in Marion County. These hydrogeologic studies primarily have focused on the glacial-outwash aquifer included in the study area for this report.

\section{Acknowledgments}

The author wishes to thank employees of the City of Indianapolis, Department of Public Works--Vasiliki Keramida, James Parks, John Babcock, and Dennis Wells--for their cooperation and assistance throughout the study. John Barr, - Kim Cussen, and staff at the IDPW laboratory provided glassware and did the majority of the sample analyses. Terry Hogan, Indianapolis Power and Light Company, provided monthly surface-water levels for the White River just downstream from the study area. Charles Crawford, U.S. Geological Survey, Indiana District office, designed and programmed the statistical models. Kevin Breen, U.S. Geological Survey, Ohio District office, provided an excellent technical review of the report.

\section{METHODS OF INVESTIGATION}

Ground-water quality and hydrogeologic data were obtained from 11 observation wells installed at the Belmont sludge lagoons. Geologic data also were obtalned from previous work at the Belmont sludge lagoons by R. A. Pettijohn (U.S. Geological Survey, written commun., 1978) who installed shallow and deep wells at sites $I$ and $J$ ( $f 1 g .2)$ ). These wells no longer existed at the time of this study.

Many statistical procedures were used during the study to detect significant differences in duplicate samples, ground-water quality with depth, and ground-water quality between locations. The sampling and analysis of ground water included a quality-assurance and quality-control program. 


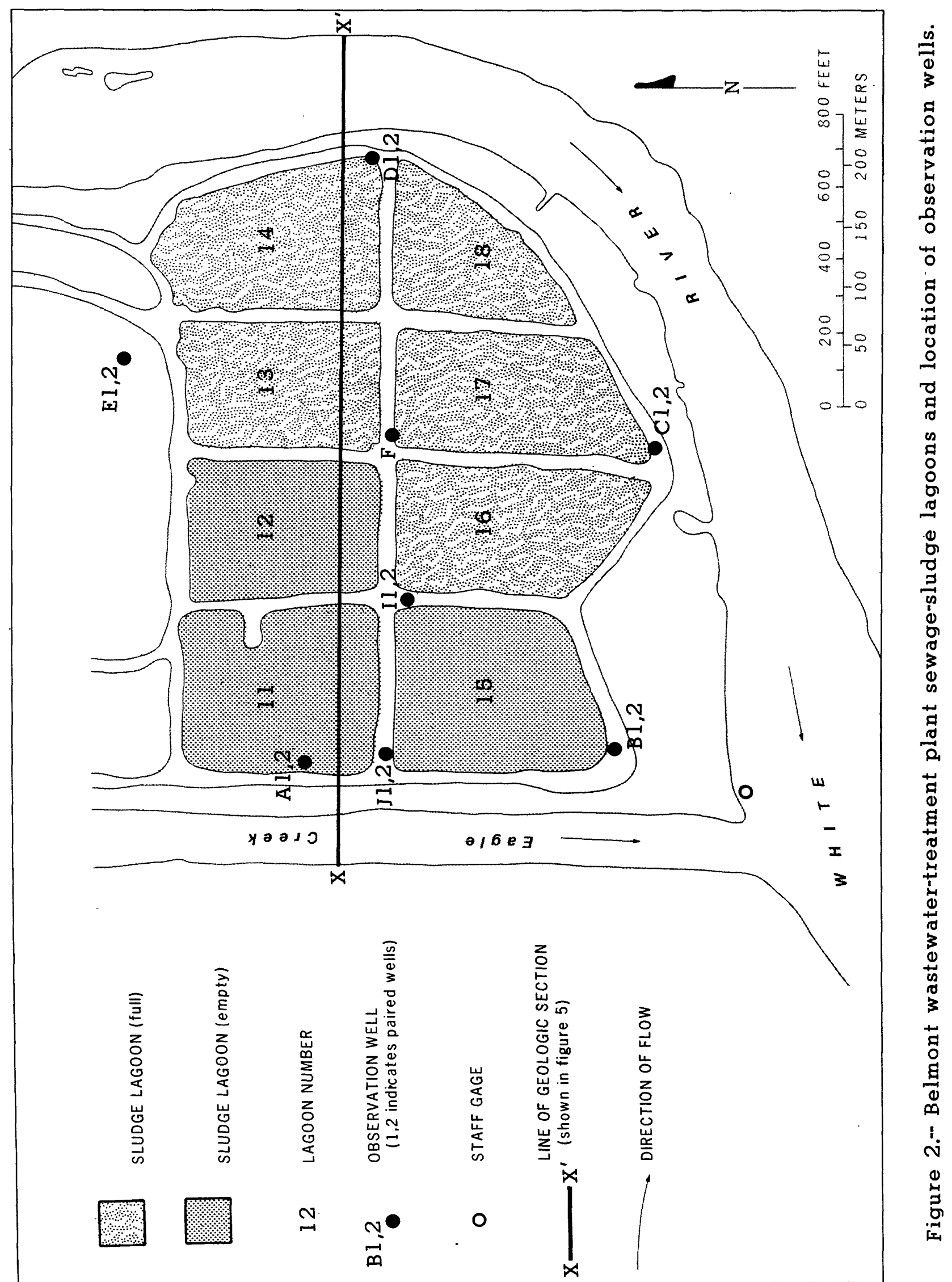


Nine observation wells were drilled by hollow-stem auger through the levees surrounding the sludge lagoons and were screened in the outwash aquifer 30 to $80 \mathrm{ft}$ (feet) beneath the levee surface. Shallow and deep paired wells were drilled at sites $B, C, D$, and $E$ ( $f$ ig. 2). One shallow well was drilled in the center of the area at site $F$. Palred wells also were installed at site A through the bottom of lagoon no. 11, which recently had been emptied. The five paired wells were used so that vertical flow of ground water and changes in ground-water quality with depth could be assessed at each site.

Al1 wells, described in table 1 , consist of 2-1n. (1nch)-inside-diameter, type 304 stainless-steel casing with 5-ft-long screens with $0.010-1 n$. slots. After the casing was set through the 3.25-in.-inside-diameter hollow stem, the auger was rotated in reverse direction during extraction to backfill the clayrich drill cuttings in the annular space around the observation well. The casing then was pushed or pounded to the proper depth. Grout and drilling fluids, which can introduce contaminants into the ground water, were not used. All augers were steam cleaned between each hole. All wells were developed with an air compressor and equipped with a locking cap. A 1-yd ${ }^{3}$ (cubic yard) concrete collar was poured around each well at the land surface to prevent surface runoff from entering the annular space. Driller's logs, split-spoon samples, and natural gamma-ray geophysical logs were examined to define the 1ithology beneath the sludge lagoons and to determine the proper altitudes for the well screens.

Ground-water and surface-water levels of the lagoons and adjacent streams were measured on a semimonthly basis from June 1986 through July 1987. Water levels in White River and Eagle Creek at points adjacent to the lagoons were estimated by straight-line interpolation between upstream bridge measurements and a staff gage at the confluence.

The ground water beneath the sludge lagoons was sampled during 1-week periods in July 1986, October 1986, January 1987, May 1987, and July 1987. Samples were analyzed for the dissolved forms of the following constituents: calcium, magnesium, sodium, potassium, total alkalinity, sulfate, chloride, dissolved sollds (DS), arsenic, barium, boron, bromide, cadmium, total chromium, hexavalent chromium, copper, Iron, lead, manganese, mercury, nickel, selenium, zinc, nitrate nitrogen, nitrite nitrogen, ammonium nitrogen, organic nitrogen, total phosphorus, chemical oxygen demand (COD), and total phenols. Concentration of DS is residue on evaporation at $103{ }^{\circ} \mathrm{C}$ (degrees Celsius). Total recoverable methylene-blue-active substances (MBAS) also were analyzed. In addition, samples were analyzed for total coliform, fecal coliform, and fecal streptococcl bacteria. The membrane filter method was used for all bacterial analyses. Total coliform colonies were grown on $M$-Endo broth medium, fecal coliform colonies were grown on M-FC medium, and fecal streptococcl colonies were grown on KF streptococcus agar. 
Table 1.--Description of observation wells at the Belmont sewage-sludge lagoons

[Altitude, in feet, refers to distance above sea leve1]

\begin{tabular}{|c|c|c|c|}
\hline We11 1 & $\begin{array}{l}\text { Altitude of } \\
\text { land surface, } \\
\text { in feet }\end{array}$ & $\begin{array}{c}\text { Depth of } \\
\text { casing and } \\
\text { screen below } \\
\text { land surface, } \\
\text { in feet }\end{array}$ & $\begin{array}{c}\text { Altitude of } \\
\text { screened interval, } \\
\text { in feet }\end{array}$ \\
\hline $\begin{array}{l}\text { A1 } \\
\text { A2 }\end{array}$ & $\begin{array}{l}673.5 \\
673.5\end{array}$ & $\begin{array}{l}65.2 \\
15.9\end{array}$ & $\begin{array}{l}603.3-608.3 \\
652.6-657.6\end{array}$ \\
\hline $\begin{array}{l}\text { B1 } \\
\text { B2 }\end{array}$ & $\begin{array}{l}688.5 \\
688.5\end{array}$ & $\begin{array}{l}75.1 \\
31.1\end{array}$ & $\begin{array}{l}608.4-613.4 \\
652.4-657.4\end{array}$ \\
\hline $\begin{array}{l}\mathrm{C} 1 \\
\mathrm{C} 2\end{array}$ & $\begin{array}{l}688.2 \\
688.2\end{array}$ & $\begin{array}{l}73.4 \\
30.4\end{array}$ & $\begin{array}{l}609.8-614.8 \\
652.8-657.8\end{array}$ \\
\hline $\begin{array}{l}\text { D1 } \\
\text { D2 }\end{array}$ & $\begin{array}{l}688.8 \\
688.8\end{array}$ & $\begin{array}{l}47.0 \\
30.2\end{array}$ & $\begin{array}{l}636.8-641.8 \\
653.6-658.6\end{array}$ \\
\hline $\begin{array}{l}\text { E1 } \\
\text { E2 }\end{array}$ & $\begin{array}{l}686.9 \\
686.9\end{array}$ & $\begin{array}{l}69.6 \\
30.2\end{array}$ & $\begin{array}{l}612.3-617.3 \\
651.7-656.7\end{array}$ \\
\hline $\mathbf{F}$ & 689.7 & 31.1 & $653.6-658.6$ \\
\hline
\end{tabular}

${ }^{1}$ Numbered wells with same letter prefix represent paired we11s $(1=$ deep we11; 2 = shallow we 11$)$.

"Dissolved" is defined for the U.S. Geological Survey by Feltz and others (1985, p. 1-2) as: "Constituents of a whole water sample which pass through a $0.45 \mu \mathrm{m}$ (micrometer) membrane filter...It is recognized that some types of water samples will contain colloidal material which passes through the $0.45 \mu \mathrm{m}$ filter." "Total recoverable" is defined by Feltz and others (1985, p. 1-7) as: "The amount of a given constituent that is in solution after a...sample has been digested by a method that results in dissolution of readily soluble substances."

Before sampling, a minimum of three casing volumes were removed from each well; pumping continued until $\mathrm{pH}$, temperature, dissolved oxygen (DO), and specific conductivity stabilized. The samples were collected through a 2-in., low-volume submersible pump; filtered and acidified (if required); and stored on ice. Samples were analyzed at the IDPW laboratory in the Belmont plant or at the U.S. Geological Survey National Water-Quality Laboratory in Arvada, Colorado. Coolers that contained the IDPW samples were sealed with evidence tape and were accompanied by chain-of-custody forms. 
Analyses for bacteria were hampered by interference from 1ron and turbidity. The initial sample-collection procedure for bacteria consisted of sterilizing a tefion baller with methanol, flaming or evaporating excess methanol, collecting the water sample with the baller, and depositing the sample into autoclaved bottles. Evacuation of the wells with the submersible pump prior to sample collection falled to remove the top 6 in. of water from the wells. This water commonly accumulates bacterial colonies and contains suspended iron and other constituents (K1rkland, R. T., U.S. Geological Survey, oral commun., 1986). Additional evacuation with the baller also falled to completely remove this water. Therefore, the bacteria samples probably contained some of this contaminated water. Upon filtering and incubating the sample, indicator bacterla growth was altered; results were unrellable. During the January 1987 sample collection, duplicate bacteria samples were collected from certain wells using the submersible pump. Results we encouraging; interference was minimal. Bacteria samples during May 1987 and July 1987 were collected using the submersible pump. Because of interference, all results for fecal coliform, total coliform, and fecal streptococcus bacteria in this study should not be viewed as absolute counts, but rather as maximum relative numbers when comparing wells.

\section{Quality-Assurance and Quality-Control Program}

Quality assurance ( $Q A$ ) and quality control ( $Q C$ ) consisted of one blank (deionized water) and one duplicate sample on each of the five sampling dates (18 percent of the total samples). Results of the blank analyses are summarized in table 2. Median and maximum detected levels, plus the laboratory detection 11mit are shown for each constituent in the table. Constituents that were detected more than once in the blanks include COD, fecal streptococci, DS, nitrate nitrogen, ammonium nitrogen, phosphorus, and MBAS. The W1lcoxon signed-rank procedure (Ryan and others, 1985, p. 286) was run on the difference between duplicate samples to determine if the mean was significantly different from zero. Results, shown in table 3, indicate that there was no evidence to reject the null hypothesis (no difference between duplicate samples) at the 0.05 level of significance for any of the constituents.

In addition to the QA-QC program specific to this study, the IDPW participates in the semiannual Standard Reference Water Sample (SRWS) qualityassurance program of the U.S. Geological Survey's National Water-Quality Laboratory. Results from the SRWS program during the study are shown in table 4. The IDPW laboratory analyzed four samples for major constituents, three samples for trace constituents, and three samples for nutrients. Individual ratings of 1 or 0 are questionable or poor. Of the 91 constituent analyses, only 11 were questionable or poor (12 percent). The IDPW laboratory results were the most inconsistent for trace constituents. Therefore, duplicate samples of several trace constituents (arsenic, cadmium, total chromium, and selenium) also were analyzed at the U.S. Geological Survey National WaterQuality Laboratory during the study. 


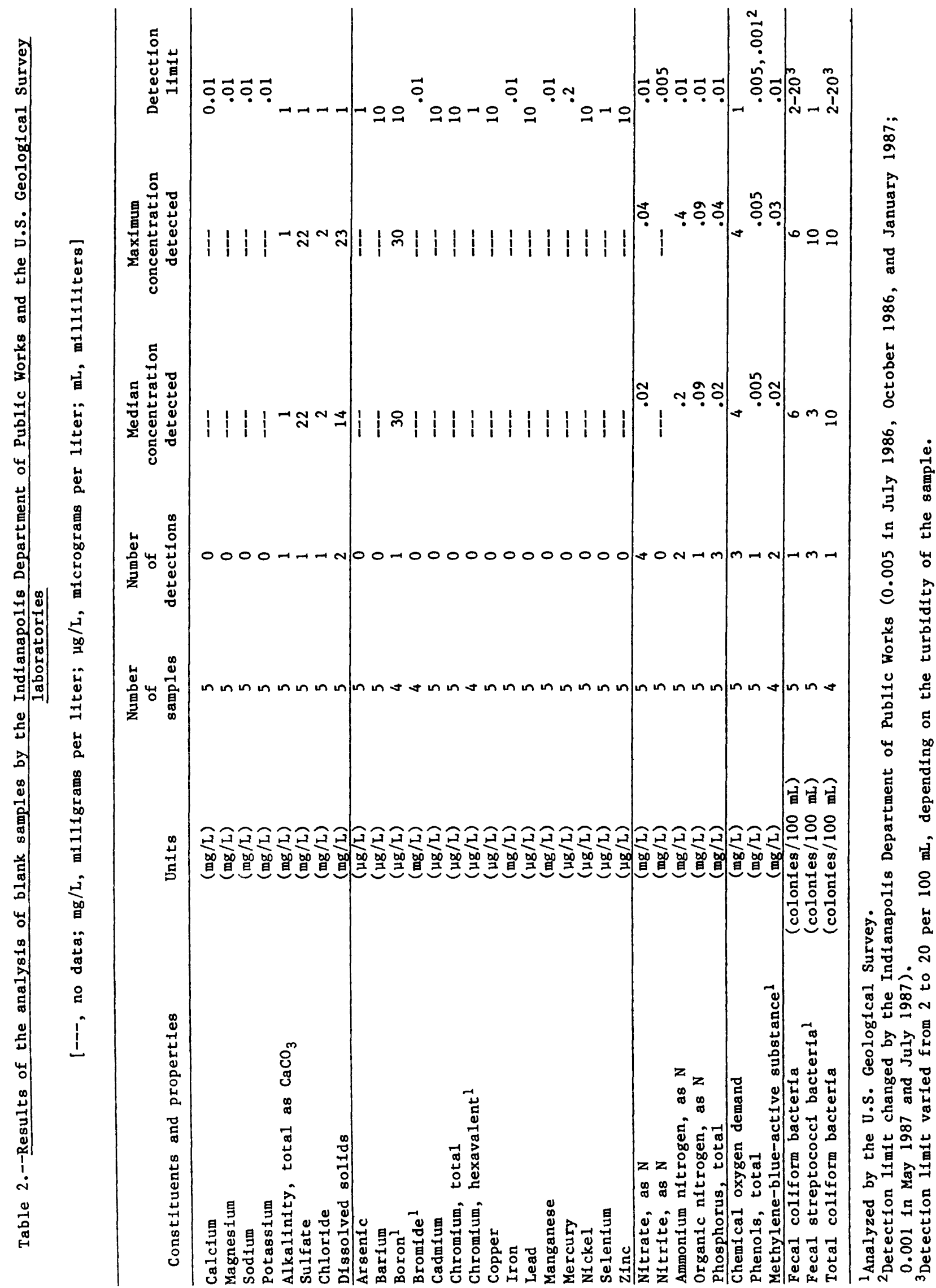


Table 3.--Summary of results from the Wilcoxon signed-rank test to determine differences in duplicate samples

[p, the probability that an observed difference is due to chance rather than a causal relation; $p<0.01$ implies highly significant difference between duplicate samples. Analysis by the IDPW laboratory unless noted otherwise]

\begin{tabular}{lc}
\hline \multicolumn{1}{c}{ Constituents and properties } & $\begin{array}{c}\text { Level of } \\
\text { significance } \\
(\mathrm{p})\end{array}$ \\
\hline Calcium & 0.99 \\
Magnesium & .79 \\
Sodium & .79 \\
Potassium & .28 \\
Alkalinity, total as $\mathrm{CaCO}_{3}$ & .89 \\
Sulfate & .37 \\
Chloride & .79 \\
Dissolved solids & .59 \\
Arsenic & .99 \\
Barium & .99 \\
Boron & .10 \\
Bromidel & .79 \\
Iron & .28 \\
Manganese & .37 \\
Nitrate, as N & .86 \\
Ammonium nitrogen, as N & .22 \\
Organic nitrogen, as N & .86 \\
Phosphorus, total & .42 \\
Chemical oxygen demand & .79 \\
Phenols, total & .37 \\
Methylene-blue-active substance & .79 \\
\hline IAnalved & \\
\hline
\end{tabular}

${ }^{1}$ Analyzed at the U.S. Geological Survey National WaterQuality Laboratory. 
Table 4.--Results of Standard Reference Water Sample quality-assurance program for the Indianapolis Department of Public Works laboratory

$$
\text { [--, no data] }
$$

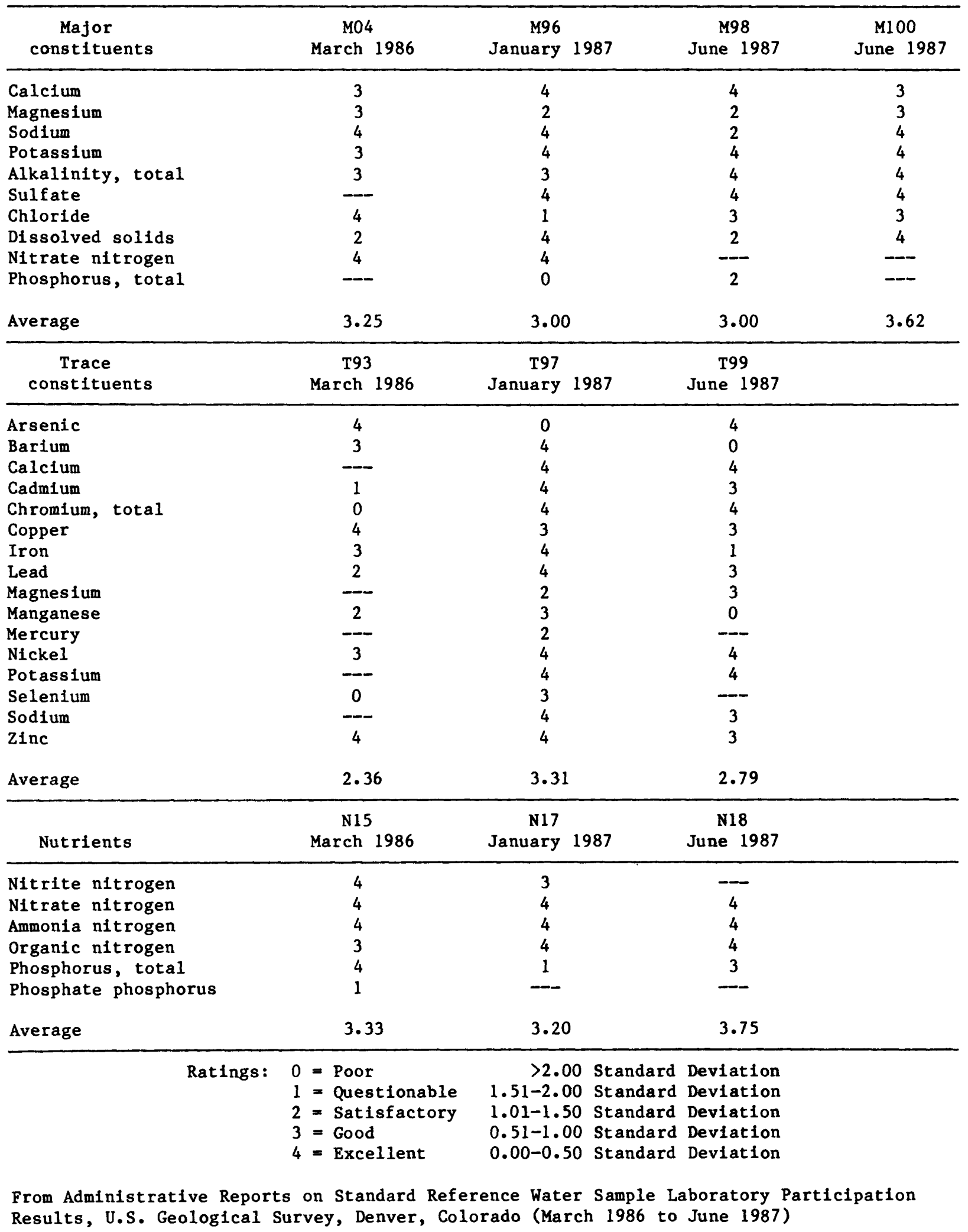


Statistical Analysis

A number of statistical tests were applied to interpret the ground-waterquality data. Nonparametric procedures were used in all the statistical analyses reported here because water-quality data typically do not meet the assumptions required by parametric or classical statistical procedures. Advantages of some nonparametric procedures are (1) they are distributionfree--that is, they do not depend on a specific distribution of the data, such as the normal or Gaussian distribution, (2) they are more efficient than parametric procedures when sampling from a nonnormal population (increased efficlency indicates better use of the data and enables a better estimate from a smaller sample size), (3) they are more powerful when samples are collected from nonnormal populations (the power of a test is the probability of rejecting the null hypothesis when $1 t$ is indeed false), and (4) they are less influenced by occasional "outliers"--that is, they are resistant to distortion by anomalous data (Conover and Iman, 1981; Iman and Conover, 1983, p. 256-257; Ryan and others, 1985, p. 276).

The Wilcoxon signed-rank test was run with the Minitabl statistical system (Ryan and others, 1985, p. 286) to determine whether there were any statistically significant differences between the paired duplicate samples of the QA-QC data. The Wilcoxon signed-rank test is equivalent to doing a paired $t$-test on the rank transformations of the data. The Wilcoxon test is more powerful than the paired t-test when the normality assumption is not met, and nearly as good when it is met. This procedure assumes only that the differences between duplicate samples are independent and identically distributed, and that their distribution is symmetric (Iman and Conover, 1983, p. 257-258).

A procedure developed Independently by Wilcoxon (1945) and Mann and Whitney (1947), the Wilcoxon-Mann-Whitney rank-sum test, was run to determine if the concentrations of certain constituents in the shallow aquifer at the sludge lagoons were different from the deep aquifer. Four constituents were tested with this procedure because they had no paired sample from the landf 111 , as required in the nested ANOVA: boron, organic nitrogen, MBAS, and fecal streptococci. Concentrations of total phenols also were compared with the rank-sum test because changes in detection limits made paired comparisons with landfill concentrations inappropriate.

The Wilcoxon-Mann-Whitney rank-sum test is equivalent to the two-sample t-test on the rank-transformed concentrations of each constituent. Ranks are assigned to the two sample populations combined; sample mean, variance, and a pooled standard deviation are calculated. This test assumes that samples are independent, randomly collected, and have identical population distributions, except for the means (Iman and Conover, 1983, p. 280-281). This test also was run with the Minitab statistical system (Ryan and others, 1985). For a thorough discussion of the applicability of the t-test and the rank-sum test, see Conover (1980) and Montgomery and Loftis (1987).

lUse of trade names in this report is for descriptive purposes only and does not constitute endorsement by the U.S. Geological Survey. 
An unbalanced, rank-transform ANOVA (Conover and Iman, 1981) was run on the ground-water-quality data from the lagoons and the landfill to determine whether concentrations varied over time (seasonality) and between shallow and deep aquifers at the sites. The unbalanced procedure is used when two populations contain different numbers of observations. The General-Linear Models (GLM) procedure for unbalanced ANOVA was done with the Statistical Analysis System (SAS) software package (SAS Institute, Inc., 1985, p. 440). The model used:

$$
Y_{1 j}=\mu+S_{i}+R_{(i)}+L_{j}+S_{i j}+e_{(i j)} \text {, }
$$

where $Y_{1 j}$ is the concentration of the water-quality constituent of interest obtained from the $j^{\text {th }}$ aquifer ( $j=s h a l l o w$, deep) of the $i^{\text {th }}$ sample $(i=1,2, \ldots 5)$ date,

$\mu$ is the overall mean of the concentration from the population of interest,

$S_{i}$ is the effect of the $i^{\text {th }}$ sample,

$R_{(i)}$ is the restriction error due to the restriction on randomization of the samples,

$L_{j}$ is the effect of the $j^{\text {th }}$ aquifer,

$S L_{i j}$ is the effect of the interaction of the $1^{\text {th }}$ sample with the $j^{\text {th }}$ aquifer, and

e(ij) is the random-error component.

Aquifer is a means component, whereas sample and the interaction term are variance components. The restriction term reflects the fact that the five sampling periods are sequential and were not randomly selected (Anderson and McLean, 1974, p. 124). Three testable hypotheses were evaluated with the mode 1:

(1) No difference between samples: $s_{1}-s_{i *}=0, \quad(i=1,2, \ldots 5$;

$\left.i *=1,2, \ldots 5 ; i \neq i^{*}\right)$,

(2) No difference between aquifers: $L_{j}-L_{j} *=0,(j=s h a l l o w ;$

$j^{*}=$ deep), and

(3) No interaction effect between samples and aquifers:

$$
S L_{1 j}-S L_{1 j *}-S L_{i * j}+S L_{i * j *}=0 \text {. }
$$


A nested ANOVA with fixed factors was run on the rank-transformed data to determine the significance of the difference between the quality of ground water from the deep and shallow aquifers at the sludge lagoons, and between the quality of ground water at the sludge lagoons and at the landfill. The method of contrasts was used to allow a more powerful and focused comparison of effects in the ANOVA (Rosenthal and Rosnow, 1985, p. 3-4). Contrasts are preferred to some alternative methods such as the multiple t-test, which 10 es significance with more than two comparisons (Sokal and Rohlf, 1969, p. 238).

The nested factorial design of the ANOVA is shown below:

\begin{tabular}{l|l|l|l|}
\cline { 3 - 3 } & & \multicolumn{2}{c}{ LOCATION } \\
\cline { 3 - 4 } AQUIFER & SHALLOW & & \\
\cline { 3 - 4 } & DEEP & & \\
\cline { 3 - 4 } & & &
\end{tabular}

The nested ANOVA treats the shallow and deep aquifers as nested within each location (lagoon and landfili). The model is:

$$
Y_{1 j}=\mu+A_{1}+B_{(1) j}+e_{(1 j) k} \text {, }
$$

where $Y_{1 j}$ is the concentration of the water-quality constituent of interest obtained from the $j^{\text {th }}$ aquifer ( $j=$ shallow, deep) in the $1^{\text {th }}$ location ( $1=1$ agoon, landf 111 ),

$\mu$ is the overall mean of the concentration from the population of interest,

$A_{1}$ is the effect of the $1^{\text {th }}$ location,

$B(1) j$ is the effect of the $f^{\text {th }}$ aquifer in the
$1^{\text {th }}$ location, and

e $(i j) k$ is the random-error component.

Therefore, to compare a constituent concentration in the shallow aquifer beneath the lagoon with the concentration in the shallow aquifer beneath the landfill, the null hypothesis becomes $H_{0}: Y_{11}=Y_{21}$, and the model becomes:

$$
\mu+\mathrm{A}_{1}+\mathrm{B}_{(1) 1}+\mathrm{e}_{(12) \mathrm{k}}=\mu_{2}+\mathrm{A}_{(2) 1}+\mathrm{e}_{(21) \mathrm{k}},
$$

which reduces to:

$$
A_{1}-A_{2}+B_{(1) 1}-B_{(2) 1}=0 \text {. }
$$

The contrast option of the SAS GLM procedure (SAS Institute, Inc., 1985, p. 441) was used to compare constituent concentrations in the shallow lagoon with the shallow landf111, deep lagoon with the deep landfill, and shallow lagoon with the deep lagoon. 
Indianapolis and Marion County are combined politically into one governmental unit. The population of Marion County was 779,966 in 1985. Within an area of $392 \mathrm{mi}^{2}$ (square miles), the population density is approximately 2,000 per $\mathrm{mi}^{2}$ (State Information Center, oral commun., 1987). The study area is shown in figure 1.

The climate of central Indiana is characterized as temperate; average annual precipitation is $40 \mathrm{in}$. Two-thirds of the precipitation is lost by evaporation and transpiration. Temperatures range from an average low of $22^{\circ} \mathrm{F}$ (degrees Fahrenheit) in January to an average high of $88^{\circ} \mathrm{F}$ in July (National Oceanic and Atmospheric Administration, 1986).

The two major streams within the study area are the White River and Eagle Creek. The White River at Morris Street in Indianapolis drains 1,635 $\mathrm{mi}^{2}$. The average dally discharge at this U.S. Geological Survey streamflow-gaging station (fig. 1), located $3 \mathrm{mi}$ upstream from the sludge lagoons, for 1981 to 1986 was $1,393 \mathrm{ft}^{3} / \mathrm{s}$ (cubic feet per second). The minimum daily discharge during the 1-year data-collection period was $115 \mathrm{ft}^{3} / \mathrm{s}$ on September 10, 1986; maximum dally discharge was $6,590 \mathrm{ft}^{3} / \mathrm{s}$ on June 8,1986 . The 7-day, 10-year low flow is $53 \mathrm{ft}^{3} / \mathrm{s}$ (Glatfelter and others, 1987, p. 138; Stewart, 1983, p. 122). Stage in the White River near the study area is affected by the Indianapolis Power and Light Company's (IPALCO) overflow concrete dam located approximately $1 \mathrm{mi}$ (mile) downstream from the Belmont sludge lagoons.

Eagle Creek drains $210 \mathrm{mi}^{2}$ at its confluence with the White River in Indianapolis. The flow is controlled by release from a 24,000 acre-ft reservoli located $13 \mathrm{mi}$ upstream from the confluence. A U.S. Geological Survey streamflow-gaging station is located $7 \mathrm{mi}$ upstream from the confluence (fig. 1). Average dally discharge at the station is $156 \mathrm{ft}^{3} / \mathrm{s} ; 7$-day, 10-year low $\mathrm{flow}$ is $6.0 \mathrm{ft}^{3} / \mathrm{s}$. Minimum dally discharge for the data-collection period was $9.2 \mathrm{ft}^{3} / \mathrm{s}$ on September 10, 1986; maximum daily discharge was $1,650 \mathrm{ft}^{3} / \mathrm{s}$ on October 4, 1986 (Glatfelter and others, 1987, p. 143; Stewart, 1983, p. 128).

Belmont Advanced Wastewater-Treatment Plant and Sewage-Sludge Lagoons

The IDPW currently operates two AWT plants in Marion County: Belmont and Southport. The locations are shown in figure 1. Each plant treats up to $125 \mathrm{Mgal} / \mathrm{d}$ (million gallons per day) of wastewater; all the sludge produced during treatment is processed at the Belmont Plant. The plants are Class IV, oxygen-nitrification facilities with biological roughing towers, mixed-media filters, and disinfection by ozonation (Parks, J. T., Indianapolis Department of Public Works, oral commun., 1986). Nearly 660 tons of sludge (wet weight) are produced daily at the two municipal treatment facilities. Sludge from the Belmont and Southport plants are combined and thickened by dissolved air flotation, then blended with raw, primary sludge and ash from the sludge incinerator. After vacuum filtration, the sludge is approximately 35-percent total solids and 40-percent volatile solids by dry weight (Robson and Wukasch, 1980, p. 112). Al1 of the sludge currently is incinerated at Belmont. 
The Belmont AWT plant was constructed in the early 1920's, at which time the treatment process consisted of primary clarification, followed by activated sludge treatment. The solids were pumped to five digestion pits (similar to the current lagoons) for uncontrolled anaerobic digestion. In 1935, the facilities were expanded and five additional sludge-digestion pits were constructed. At that time, the sludge was allowed to digest for $1 \mathrm{yr}$, then it was dried and dispersed to local farmers to be used as a soll amendment and fertilizer. In 1955, the current pattern of eight lagoons was constructed on 40 acres ( $f i g .2)$. For the next $29 \mathrm{yr}$, waste-activated sludge periodically was discharged to the lagoons. In the late 1970's, the original 10 lagoons were emptied and compacted with clean fill so that improvements to the AWT plant could be constructed on that site. In April 1984, disposal of sludge in the lagoons at the Belmont plant ceased (Parks, J. T., Indianapolis Department of Public Works, written commun., 1984).

In 1976, Belmont sludge lagoon no. 12 was dewatered and emptied prior to the installation of a new 120-in. AWT effluent line to the White River. At that time, an 8-in.-thick, bentonite/clay liner was placed in the lagoon bottom before being refilled (We11s, Dennis, Indianapolis Department of Public Works, oral commun., 1987). Also, sludge lagoon no. 16 was partially emptied in 1976, but no liner was installed. In 1985, the IDPW began an extensive lagoon-cleaning project. The sludge from lagoon nos. 11, 12, and 15 was dewatered and removed from 1985 to 1987. The sludge was trucked from the lagoon to sludge-drying areas or to lagoon no. 11 and alr dried before being disposed. The IDPW plans to excavate the sludge from the remaining lagoons durIng the next few years and dispose of the solids off site (Parks, J. T., Indianapolis Department of Public Works, written commun., 1984). Excavation of the lagoons will allow for the disposal of incinerator ash from the Indianapolis recource recovery facility located adjacent to the Belmont AWT plant (Keramida, Vasiliki, Indlanapolis Department of Public Works, ora1 commun., 1987).

\section{Tibbs-Banta S1udge-Amended Landfi11}

The Tibbs-Banta landf111, located just north of the IDPW Southport AWT plant ( $f$ ig. 1), was operated from 1968 through 1974 by the City of Indianapolis. The 50-acre site, shown in figure 3, is located adjacent to the White River about $4.5 \mathrm{mi}$ downstream from the Belmont plant. The landfill was operated as a free public-dump site and recelved residential refuse, demolition debris, tires, and wood (Parks, J. T., Indianapolis Department of Public Works, written commun., 1984). Although there are 18 observation wells at the site, only three pairs of wells are located downgradient from the landfill: sites I, J, and L (fig. 3; Duwellus and Greeman, in press).

In June 1983, the landfill surface was covered, graded, and contoured to prepare for a revegetation project using sludge from the Southport AWT plant. From July to September 1983, approximately $69,390 \mathrm{yd}^{3}$ of sludge was removed from Southport's lagoon no. 9, dried, and disced into the cover soil as a soil amendment over 28 acres. Drying increased the sludge solids from an initial 10 -percent total solids up to 50-percent total solids. This reduction in volume of 80 percent resulted in $13,880 \mathrm{yd}^{3}$ of sludge for disposal, or 495 dried tons per acre. This is equivalent to $3.7 \mathrm{in}$. of sludge over the 28 acres at Tibbs-Banta landf111. Cover material was placed over the sludge mixture and seeded with grass (Bastable, T. A., Indianapolis Department of Public Works, written commun., 1984). 


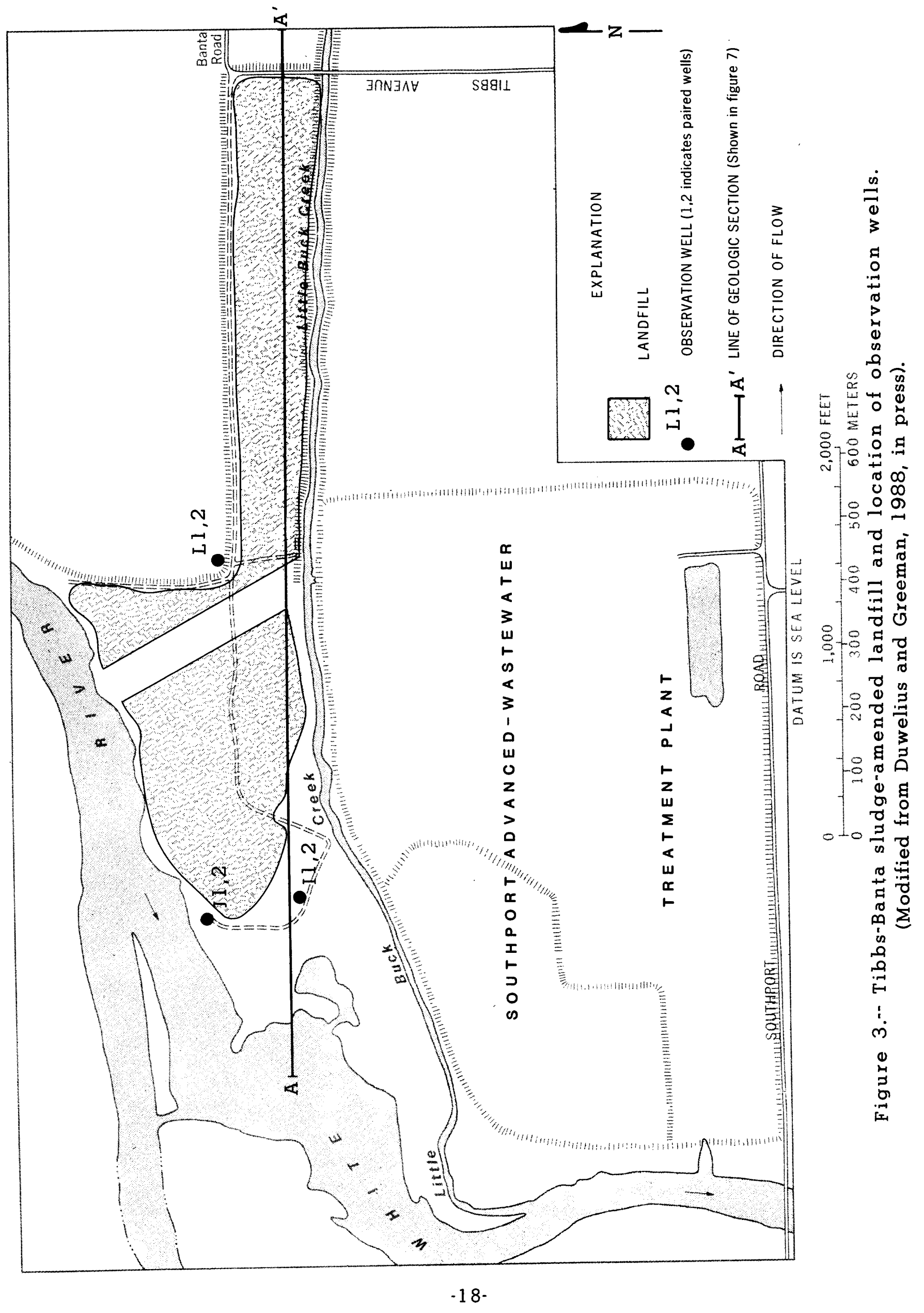


In August 1984, phase two of the program began. The remaining sludge from lagoon no. 9, or $20,027 \mathrm{yd}^{3}$, was transported to the landfill and incorporated into 17 acres. Initial total solids content ranged from 6.1 to 26.0 percent. After drying to 50 percent solids, $15,930 \mathrm{yd}^{3}$ was applied at 468.5 tons per acre or approximately 6.4 in. over the 17 acres. Finally, $34,155 \mathrm{yd}^{3}$ of soil was applied to a depth of $15 \mathrm{ln}$. over the area (Parks, J. T., Indianapolis Department of Public Works, written commun., 1984).

The quantity of metals applied to the Tibbs-Banta landfill in 1984 was calculated before application. The concentration of $123 \mathrm{lb} / \mathrm{bcre}$ (pounds per acre) cadmium in the sludge exceeded the standard for application onto land designated for food-chain crops (approximately $8 \mathrm{lb} / \mathrm{acre}$ ) because of posstble human-health hazards (Indiana Register, 1987). Other metals applied included $492 \mathrm{lb} / a c r e$ lead; 8,420 1b/acre zlnc; 2,630 1b/acre copper; and $277 \mathrm{lb} / \mathrm{acre}$ nickel (Parks, J. T., Indianapolis Department of Public Works, written commun., 1984).

\section{Characteristics of Sewage Sludge}

The IDPW implemented a lagoon-sampling and analysis plan in 1986 to determine sludge characteristics, lagoon depth, and solids content by depth at the Belmont AWT plant (Keramida, Vasiliki, Indianapolis Department of Public Works, written commun., 1986). The plan was developed under the guidance of the U.S. Environmental Protection Agency (USEPA) and the Indiana Department of Environmental Management. Three vertical composite samples were collected from three random locations within each lagoon for most of the analyses. Samples were obtained from the bottom, center, and upper $1 \mathrm{ft}$ of the sludge by using a Coliwasa-type sampling device driven into the sludge. Samples were analyzed for 129 USEPA priority pollutants, nutrients, pH, and percent solids. Partial results of this study are summarized in table 5. In 1977, the IDPW began a similar study (Reid, Quebe, Allison, Wilcox, \& Associates, Inc., 1979); at that time, all 18 lagoons were included. Three vertical composite samples were obtained from one location within each lagoon, and analyzed by the USEPA. Partial results of this study also are summarized in table 5 . Other analyses of Belmont sludge and characteristics of municipal sewage sludge throughout the United States are summarized for comparison in table 5 .

A comparison of the Belmont lagoon data in table 5 indicates the substantial variability that can occur between lagoons or within lagoons over time and space. The variability in sludge characteristics is attributed to the nature of the sewage influent to the treatment plant, the efficiency of the removal processes, and the extent of decomposition of the sludge (Sommers and others, 1976, p. 10; Sommers, 1977, p. 225). The Belmont sludge has characteristics similar to other municipal sludge. 


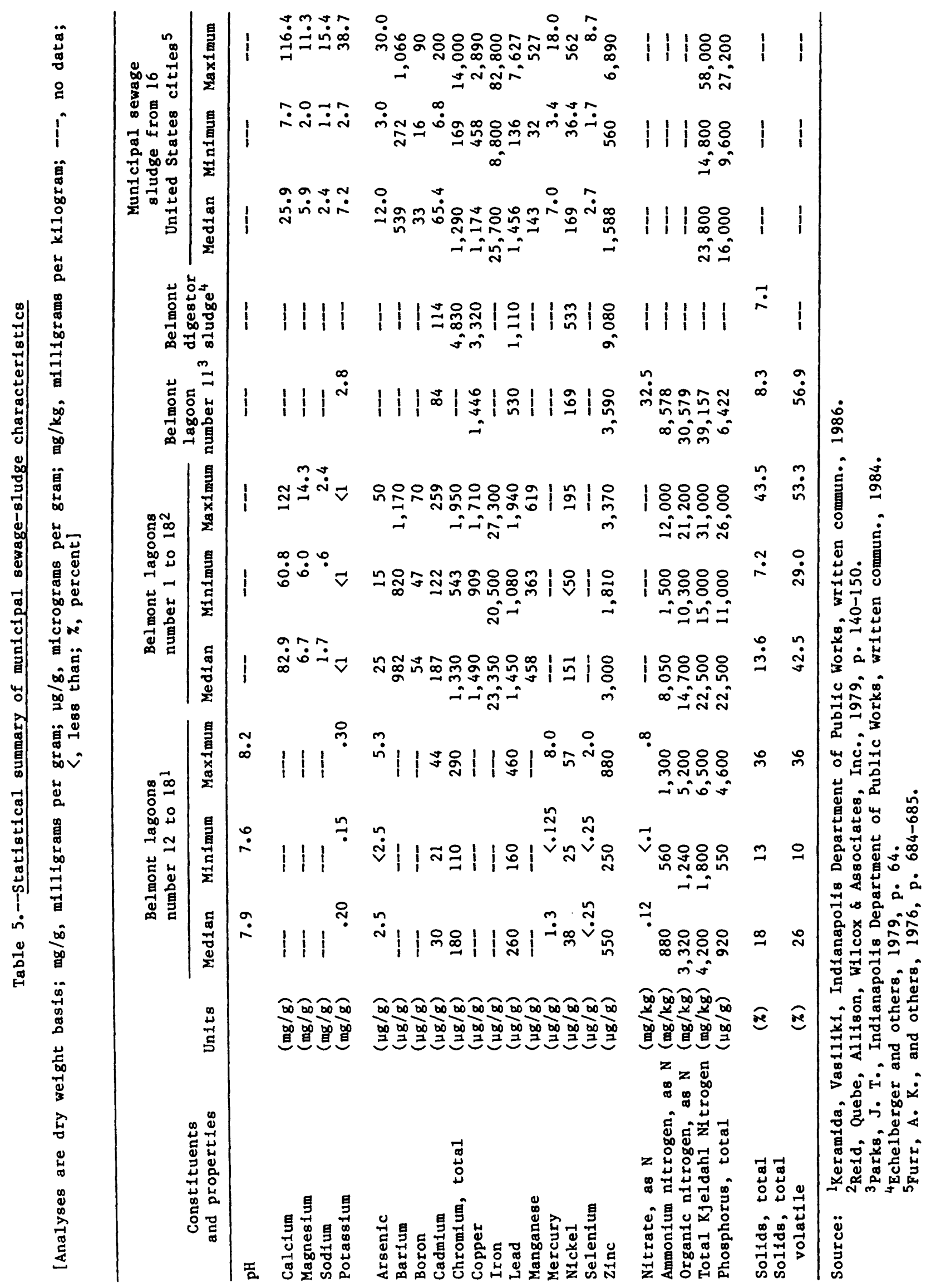


Sommers (1977, p. 226) reported that the variability in the chemical composition of sludge from a given treatment plant over time can exceed the variability between different plants. This variability might explain the difference between the median concentrations of constituents in columns 1 and 4 from table 5. Many concentrations shown from the 1977 data are an order of magnitude higher than the 1986 data. Sommers and others (1976) analyzed sewage sludge from 11 treatment plants in Indiana. Their results also indicated extreme variability of sludge characteristics within each city and between cities. They detected a significant correlation between the degree of industrialization and increased concentrations of heavy metals. Echelberger and others (1979) studied sludge from 58 municipal wastewater-treatment plants in Indiana, including the Belmont plant, to determine physical and chemical characteristics. These 58 plants represent 90 percent of the populated areas in the State that have sewers. Grab samples were collected from the sludge digestor at the plants. Concentrations of metals in the Belmont sludge (shown in table 5) were very high compared to most municipalities in the State: 5th out of 58 for copper, 8th for zinc and chromium, 9th for lead, and 11th for cadmium and nickel (Echelberger and others, 1979, p. 64).

The solids content of sludge from the Belmont lagoons also has been characterized as highly variable by Robson and Sommers (1982, p. 27). Total solids in lagoon nos. 11-18 (excluding no. 16) ranged from 0.7 to 38.2 percent. The solids content increased with depth: at $2.6 \mathrm{ft}$ the median was 6.3 percent, whereas at a depth of $15 \mathrm{ft}$ the median was 18.6 percent.

Concentrations of constituents in surface runoff give some indication of leaching ability of a waste source in a neutral, oxidizing environment. Runoff from the sludge-drying areas at the Tibbs-Banta landf 111 and the Belmont plant was analyzed by the IDPW after five rain events in 1984. Results of this cursory analysis at the Tibbs-Banta landfill indicated median concentrations of $60 \mu \mathrm{g} / \mathrm{L}$ (micrograms per 11ter) cadmium, $250 \mu \mathrm{g} / \mathrm{L}$ lead, $880 \mu \mathrm{g} / \mathrm{L} \mathrm{zinc}$, $43.1 \mathrm{mg} / \mathrm{L}$ (milligrams per 11ter) total kjeldahl nitrogen (TKN), and $1,731 \mathrm{mg} / \mathrm{L}$ DS. The only comparable analyses at the Belmont plant showed $66.6 \mathrm{mg} / \mathrm{L}$ TKN and $1,374 \mathrm{mg} / \mathrm{L}$ DS in nine samples from the sludge-drying area (Parks, J. T., Indianapolis Department of Public Works, written commun., 1984).

\section{Hydrogeologic Setting}

The geology of Marion County has been described by Harrison (1963), Cable and others (1971), and Meyer and others (1975). Unconsolidated glacial deposits, including ti11 and outwash, range in thickness from 10 to $400 \mathrm{ft}$ throughout Marion County (fig. 4). This glacial drift is composed of deposits from pre-Illinoian, Illinoian, and Wisconsin glaciations (Harrison, 1963, p. 19). The Wisconsin sands and gravels of the glacial outwash typically are overlain by more recent alluvial silt, sand, and gravels, locally known as the Martinsville Formation of Pleistocene and Holocene age. Devonian limestone underlies the glacial drift in eastern and north-central Marion County, whereas New Albany Shale of Devonian and early Mississippian age occurs beneath the drift and above the limestone elsewhere in the county. 


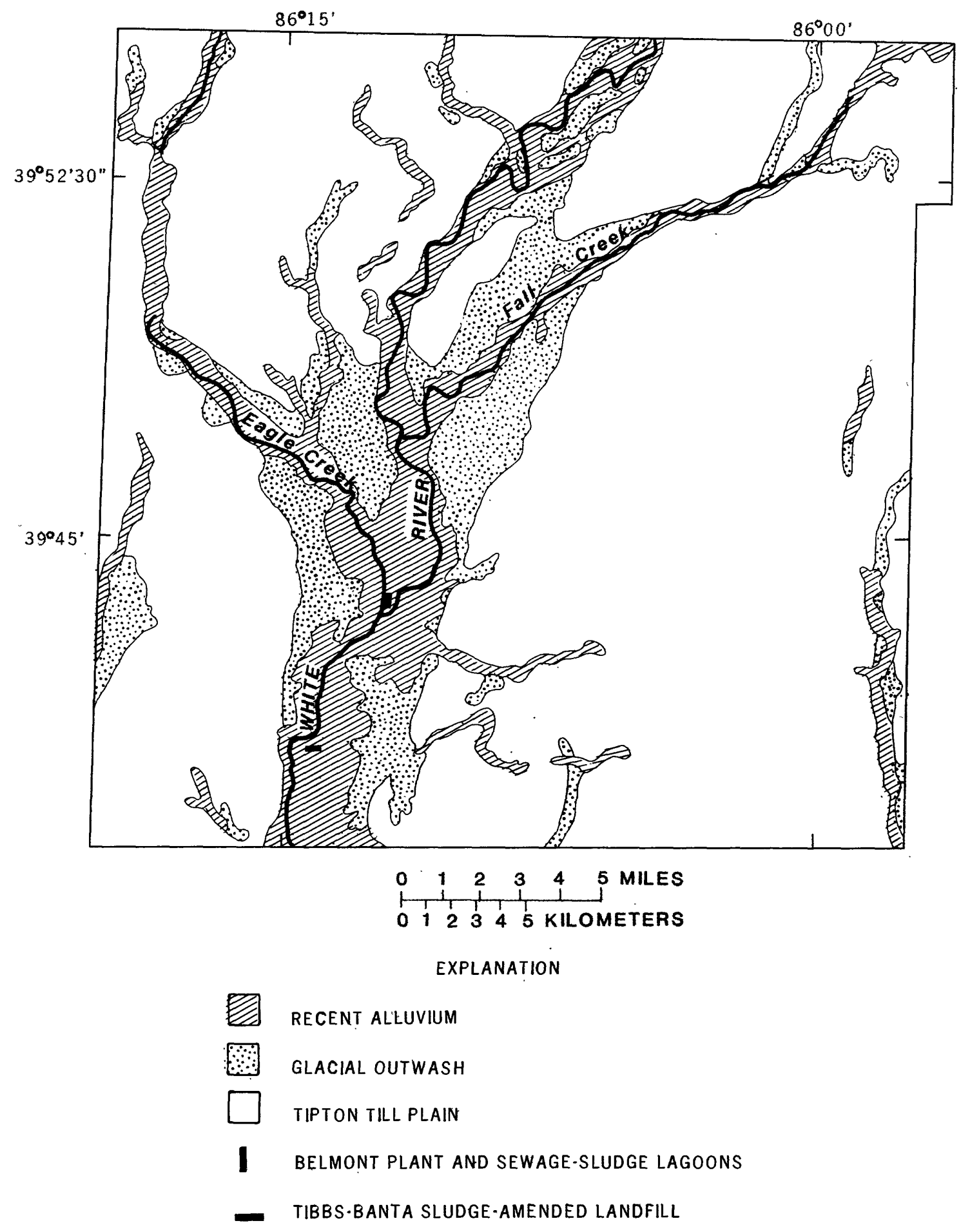

Figure 4.-- Surficial geology of Marion County.

(Modified trom Gray, Bleuer, Hill, and Lineback, 1979). 
The glacial-outwash deposits along the major surface drainages form the principal unconsolidated aquifer in the county; the aquifer ranges in thickness from 90 to $120 \mathrm{ft}$. Flow of ground water in Marion County exhibits a general pattern of downward circulation, followed by 1 ateral and upward movement before discharging to the major streams (Meyer, and others, 1975, p. 15). Another component of ground-water flow is parallel to the major drainageways in the downstream direction. Discontinuous, interbedded layers of finergrained silt and clay occur throughout the outwash aquifer. According to Meyer and others (1975, p. 9) the effect of these low-permeability layers is locally significant:

\begin{abstract}
"While clay lenses reduce the horizontal transmissivity of the aquifer to some extent, their primary effect is to reduce the vertical hydraulic conductivity; locally where this reduction is sufficient, semi-confined ground-water conditions may be found."
\end{abstract}

The Tipton Till Plain is the major physiographic feature of south-central Indiana. Characteristics of this glaciated till plain include flat topography and numerous broad valleys that trend southward and southwestward across the plain (Malott, 1922, p. 104).

Smith (1983, p. 12) used drillers' well logs to map the extent of a thick clay layer, possibly an extension of the till, under part of the Belmont plant. R. A. Pettijohn (U.S. Geological Survey, written commun., 1978) described a 10- to 15-ft-thick clay layer that extended $500 \mathrm{ft}$ eastward from Eagle Creek to the center of the sludge lagoons. He determined that the clay layer was discontinuous in several places. New Albany Shale occurred at a depth of 111 to $113 \mathrm{ft}$ beneath the levee surface.

Based on these previous studies, two aquifer layers, separated by a thick clay layer, were expected to underlie all of the well sites at the lagoons. Upon drilling the 11 new wells (fig. 2) and studying the geophysical logs of these holes, it was determined that the clay layer occurred only at site $B$ in the southwestern corner of the lagoon area. The other wells penetrated coarse sand and gravel and traces of silt and clay.

All shallow observation wells were screened 10 to $15 \mathrm{ft}$ below the water table in the shallow aquifer where the maximum concentration of leachate was expected (Kehew and others, 1983, p. 60)--that is, leachate constituents were expected to be in relatively high concentrations at a point in the aquifer closest to the waste source. At site $B$, the deep we1l was screened in sand and gravel immediately beneath the clay layer, which separates the two aquifer units. Deep wells at sites $A, C$, and $E$ were screened at approximately the same altitude as deep well B (table 1 ). References to deep and shallow aquifers or wells generally will pertain to the sand and gravel units above and below altitude $635 \mathrm{ft}$ above sea level (fig. 5). The deep well at site $D$ was screened higher in the aquifer just above a clay layer overlying shallow bedrock. New Albany Shale is only $55 \mathrm{ft}$ beneath the surface at site $D$. Vertical locations of the well screens at sites $A, D$, and $F$ also are shown in figure 5. The clay layer is thickest toward the middle of the lagoons beneath Pettijohn's site I (Pettijohn, R. A., U.S. Geological Survey, written commun., 1978), and thins to less than $2 \mathrm{ft}$ at sites $A$ and $D$. A separate, basal clay layer overlies the bedrock. The New Albany Shale caps a preglacial bedrock 
valley that recedes $60 \mathrm{ft}$ from site $D$ to beneath the center of the lagoons. The shallow water table on January 29, 1987, has been drawn showing virtually no gradient between sites $A$ and $F$, and a very slight gradient of $0.0003 \mathrm{ft} / \mathrm{ft}$ from site $F$ to site $D$. A fence diagram that shows the complexity of the 1ithology at the Belmont site is shown in figure 6. The vertical locations of the well screens also are shown.

The hydrogeology beneath the Tibbs-Banta landf 111 is very simflar to that beneath the Belmont sludge lagoons. The Tibbs-Banta landfill was constructed on alluvial sediments overlying unconsolidated glacial-outwash deposits that range in thickness from 20 to $100 \mathrm{ft}$. Bedrock beneath the landfill is composed of shale and some limestone. Multiple sand and gravel layers, separated by discontinuous clay of variable thickness, have been mapped ( $\mathrm{fig}$. 7 ) beneath the landfill (Duwelius and Greeman, in press). In this report, the term "shallow aquifer" at the landfill applies to the sand and gravel deposits above the clay layer located at approximately 620 to $630 \mathrm{ft}$ below sea leve1; the term "deep aquifer" applies to the sand and gravel deposits beneath the clay layer.

Ground water generally flows from east to west beneath the Tibbs-Banta landfill, eventually discharging to the White River. Effective recharge for the area is approximately $10 \mathrm{in} / \mathrm{yr}$. The average ground-water gradient is $10 \mathrm{ft}$ throughout the $3,000-\mathrm{ft}$ length of the landfill $(0.0033 \mathrm{ft} / \mathrm{ft})$, or approximately an order of magnitude greater than the gradient beneath the lagoons. A three-dimensional simulation of ground-water flow calibrated to static water levels on October 17, 1985, indicated that approximately $2 \mathrm{ft}^{3} / \mathrm{s}$ of ground water discharged through the aquifer beneath the landfill into the White River. For a more detailed explanation of the hydrogeology beneath the landfi11, refer to Duwelius and Greeman (in press). 


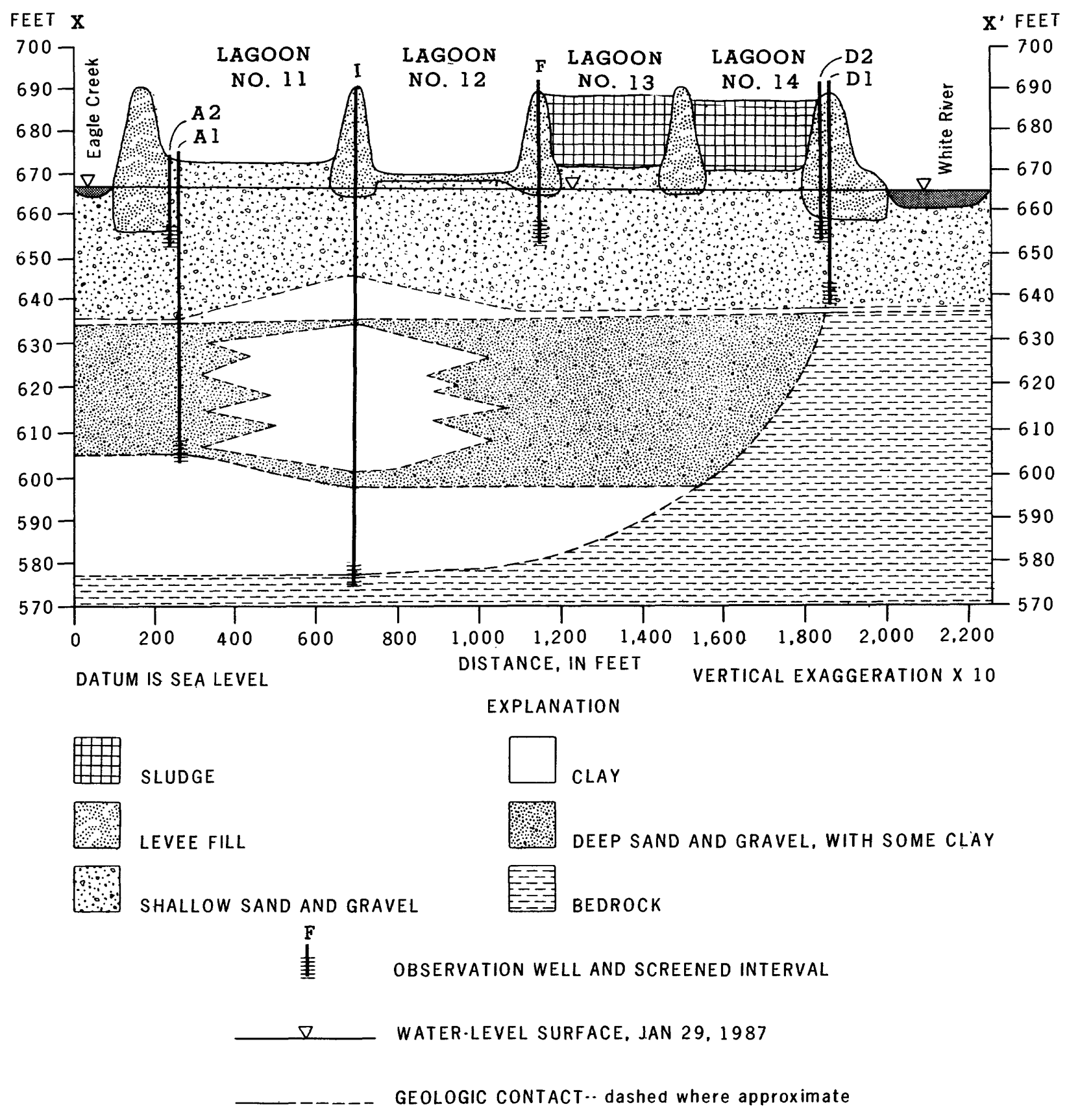

Figure 5.-- Geologic section showing generalized lithology beneath the Belmont sludge lagoons. 


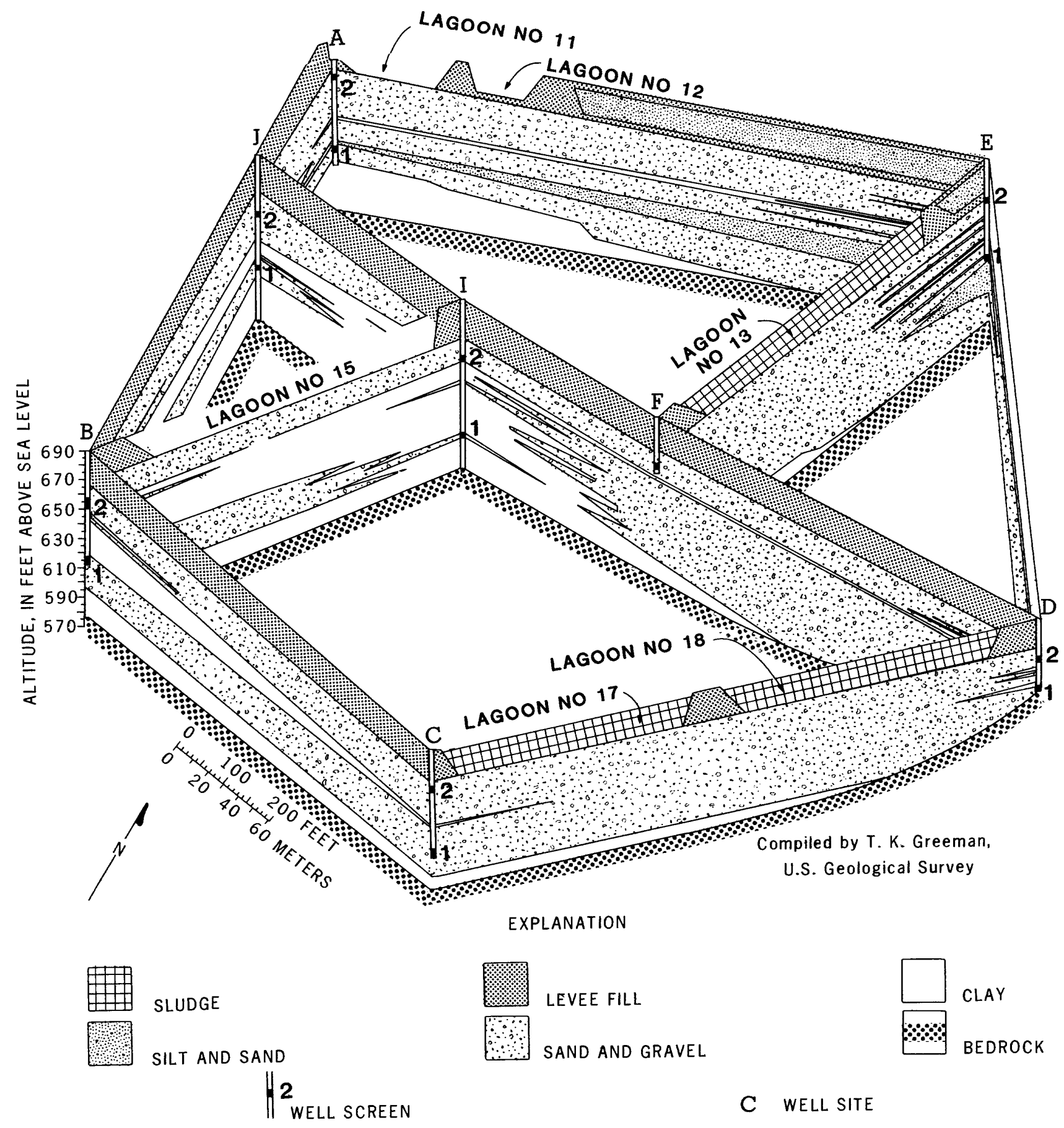

Figure 6.-- Fence diagram showing generalized lithology and location of well screens beneath the Belmont sludge lagoons. 


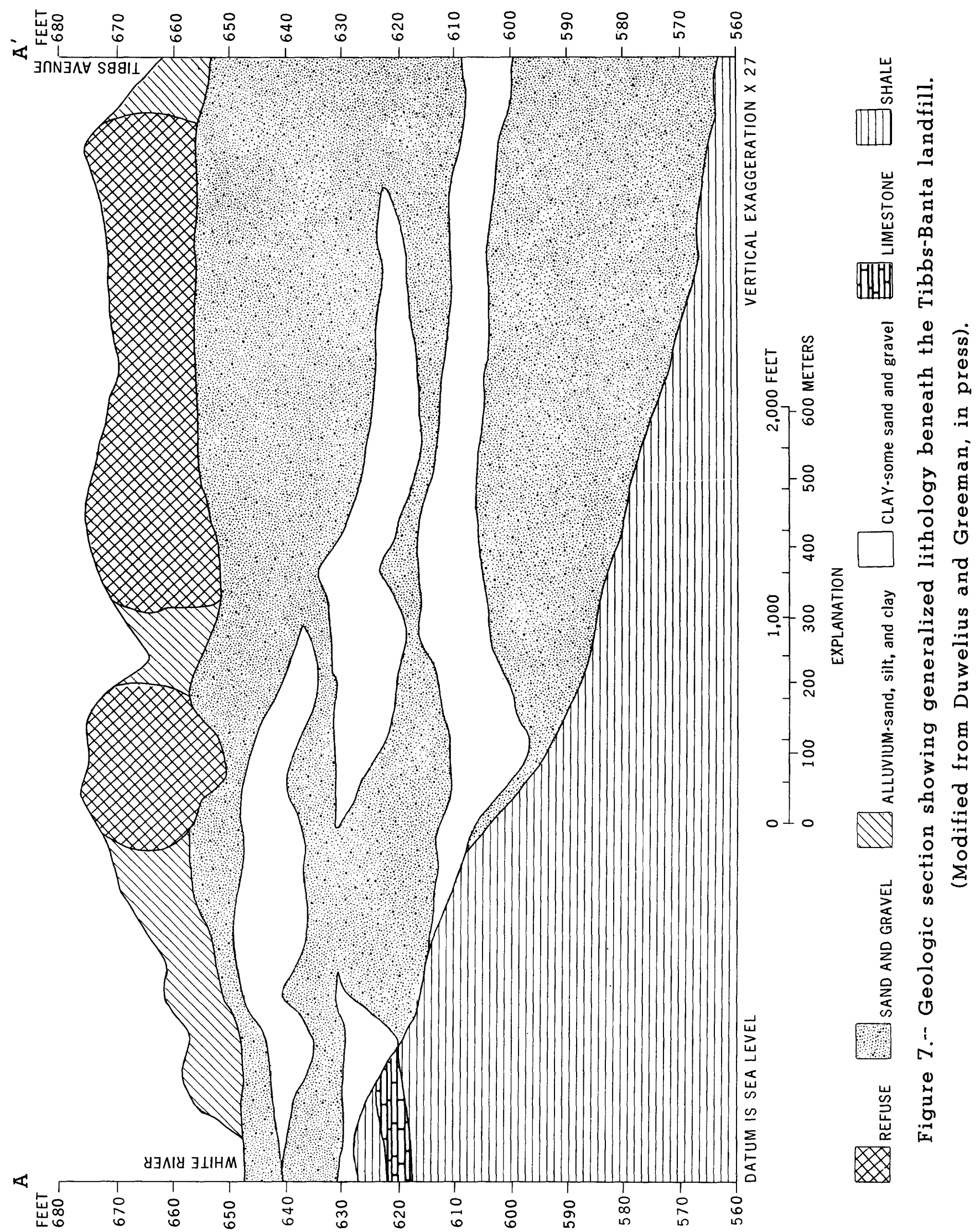


FLOW OF GROUND WATER BENEATH THE BELMONT SEWAGE-SLUDGE LAGOONS

Ground-water levels beneath the Belmont sewage-sludge lagoons were measured on approximately a semimonthly basis from June 1986 through July 1987. Surface-water levels were measured from bridges $0.5 \mathrm{ml}$ upstream on the White River and $1 \mathrm{ml}$ upstream on Eagle Creek, and at a staff gage at the confluence of the White River and Eagle Creek. Levels in the White River and Eagle Creek adjacent to the observation wells were approximated by straight-line interpolation between the bridges and the staff gage.

Water-table conditions occur in the shallow aquifer and in the full thickness of the sand and gravel aquifer where the clay layer is absent. Water in the deep aquifer is under confined conditions in the southwestern area of the lagoons where the clay layer separates the two aquifer units. Ground-water and surface-water levels are summarized in table 6.

Table 6.--Summary of ground-water and surface-water levels near the Belmont sludge lagoons, June 1986 through July 1987

[Altitude, in feet, refers to distance above sea level]

\begin{tabular}{lcccc}
\hline We11 & $\begin{array}{c}\text { Altitude of } \\
\text { mumber of } \\
\text { measurements }\end{array}$ & $\begin{array}{c}\text { Altitude of } \\
\text { water leve1, } \\
\text { in feet }\end{array}$ & $\begin{array}{c}\text { maximum } \\
\text { in fer leve1, }\end{array}$ & $\begin{array}{c}\text { Range of } \\
\text { water leve1, } \\
\text { in feet }\end{array}$ \\
\hline A1 & 33 & 665.05 & 668.69 & 3.64 \\
A2 & 33 & 665.59 & 668.44 & 2.85 \\
B1 & 32 & 664.46 & 667.33 & 2.87 \\
B2 & 33 & 664.93 & 668.62 & 3.70 \\
C1 & 32 & 664.64 & 668.46 & 3.82 \\
C2 & 32 & 664.64 & 668.28 & 3.64 \\
D1 & 31 & 664.56 & 668.18 & 3.62 \\
D2 & 32 & 664.54 & 668.08 & 3.54 \\
E1 & 32 & 665.15 & 667.96 & 2.81 \\
E2 & 32 & 665.14 & 667.95 & 2.81 \\
F & 23 & 665.06 & 667.74 & 2.68 \\
\hline Staff gage & 18 & 665.21 & 669.61 & 4.40 \\
\hline
\end{tabular}


Measured levels in the 10 paired wells (A - E) fluctuated as much as $3.82 \mathrm{ft}$ (well $\mathrm{Cl}$ ) during the sampling period. The highest levels were measured in wells Al $(668.69 \mathrm{ft})$ and B2 $(668.62 \mathrm{ft})$. The lowest level, $664.46 \mathrm{ft}$, was measured in well $\mathrm{Bl}$. The loss of hydraulic head between the shallow well, $B 2$, and the deep well, B1, indicates the efficiency of the clay layer in separating the two aquifers at site $B$. The smallest fluctuation occurred at site $E$, located farthest from the White River. The maximum level and magnitude of fluctuation were greater in the White River than in the ground water beneath the lagoons. Because the ground-water and surface-water levels were measured periodically, not continuously, it is unlikely that the actual minimum and maximum levels from June 1986 through July 1987 were measured.

Water-level measurements indicate that shallow ground-water flow is generally semiradial away from the lagoons and parallel to Eagle Creek, then discharges to the White River. A diagram showing the ground-water-flow net is shown in figure 8a. After an accumulation of approximately 2 in. of rain during 1 week or less, the White River and Eagle Creek rise above the groundwater levels beneath the lagoons. The flow to the White River 18 reversed and water flows from both streams back toward the lagoons, as shown in figure 8 b. This flow reversal is a temporary phenomenon (bank storage) that lasts from a few hours to a few days unt1l the river stage recedes below the ground-water level. The duration of these flow reversals was estimated by comparing continuous water-level records at we11 D2 with the continuous-stage record of the White River at Morris Street.

Water-table gradients in the shallow aquifer are about $0.0003 \mathrm{ft} / \mathrm{ft}$. This gradient is very low and results in extremely slow ground-water velocities. Russell and others (1987, p. 864) identified general characteristics of low-relief areas that affect the migration of local leachate plumes. Three of those characteristics apply to the shallow and deep aquifers at the Belmont site: (1) mounding of ground water that results from the storage or disposal of semiliquid wastes, (2) local ground-water sources and sinks, such as Eagle Creek, White River, and industrial pumpage, and (3) local differences in hydraulic conductivity.

D. J. Wangsness and C. G. Crawford (U.S. Geological Survey, written commun., 1986) calculated a simple water budget for the White River in Indianapolis, which indicated that the river was receiving ground-water discharge in the area of the sludge lagoons during low flow. R. A. Pettijohn (U.S. Geological Survey, written commun., 1978) also showed the shallow ground water beneath the lagoons as flowing southeast and as discharging into the White River.

The deep ground water generally flows semiradially, as shown in flgure 9a. Some of the flow discharges to the White River, whereas another component of flow is toward the south and west beneath Eagle Creek. The reversal effect with all flow away from the river and toward the southwest is shown in figure 9b. It is uncertain whether flow beyond Eagle Creek is diverted north and west by industrial pumpage or whether flow continues toward the southwest. Gradients in the deeper zone are about $0.0006 \mathrm{ft} / \mathrm{ft}$, or twice the shallow gradients. The gradient increases substantially near well $\mathrm{Bl}$, as shown in figures $9 \mathrm{a}$ and $9 \mathrm{~b}$. 


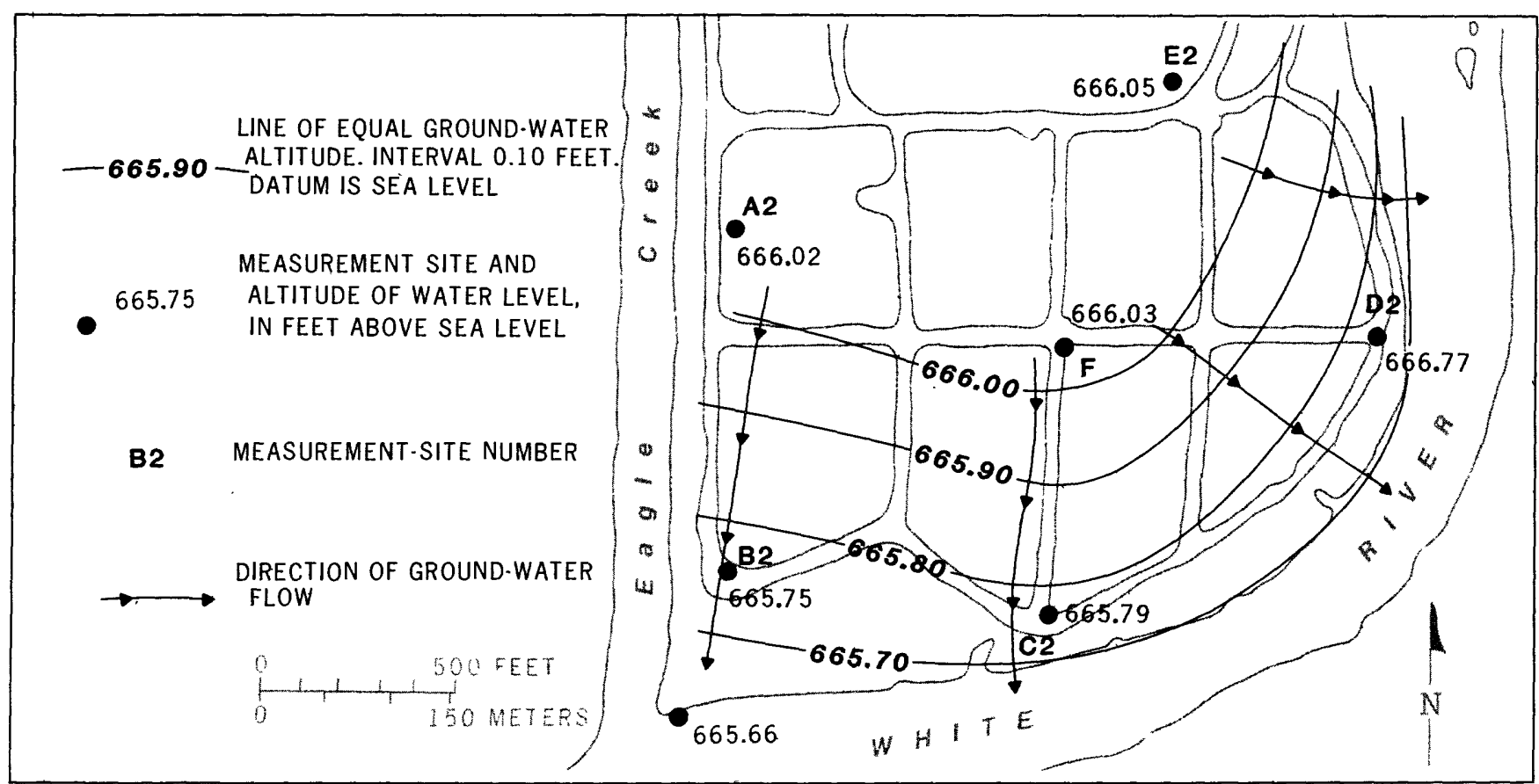

Figure 8a.-- Altitude of the water table and general direction of shallow ground-water flow beneath the Belmont sludge lagoons, January 29, 1987.

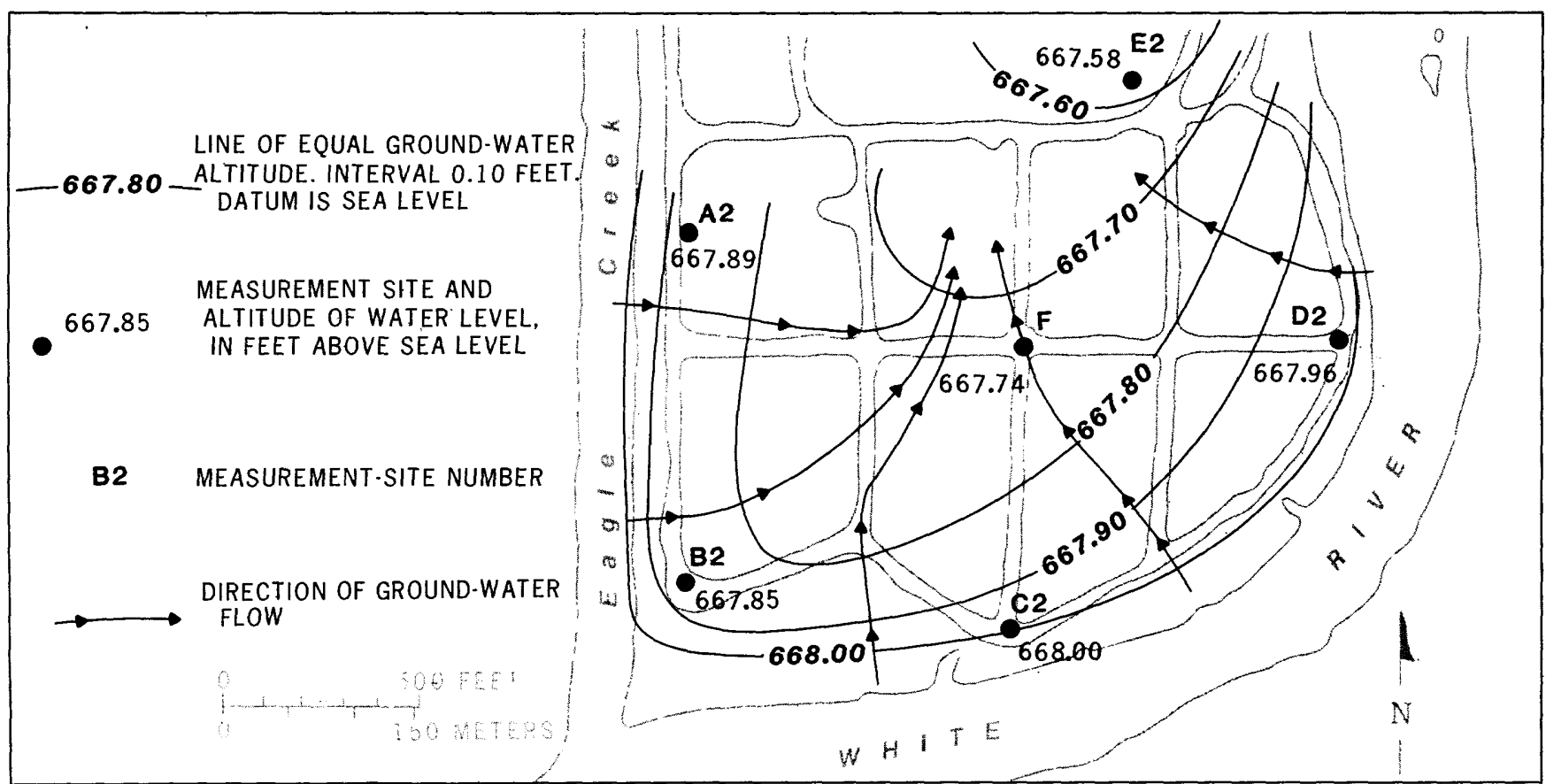

Figure 8b.-- Altitude of the water table and reversed direction of shallow ground-water flow beneath the Belmont sludge lagoons, October 2, 1986. 


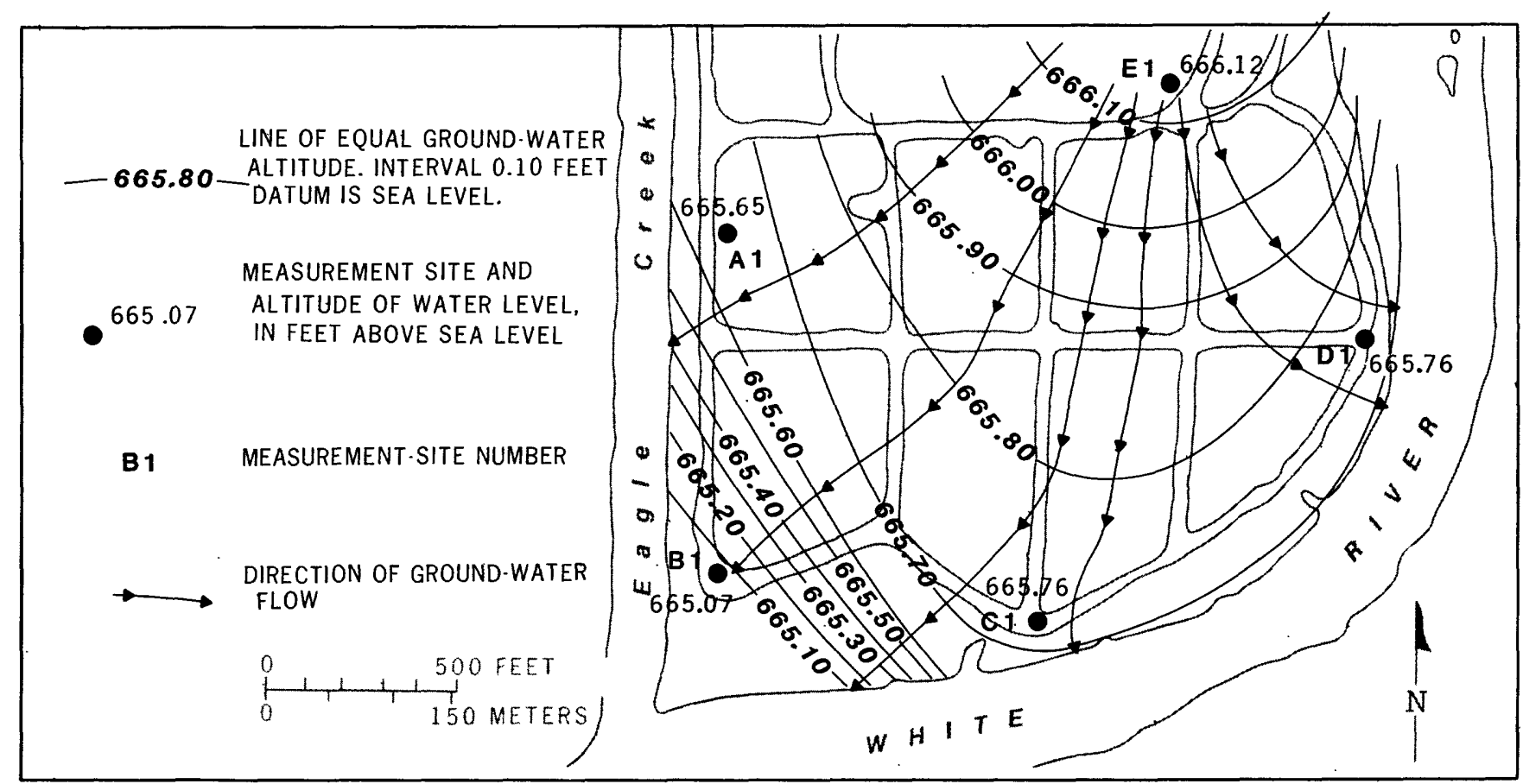

Figure 9a.-- Altitude of the water table and general direction of deep ground-water flow beneath the Belmont sludge lagoons, January 29, 1987.

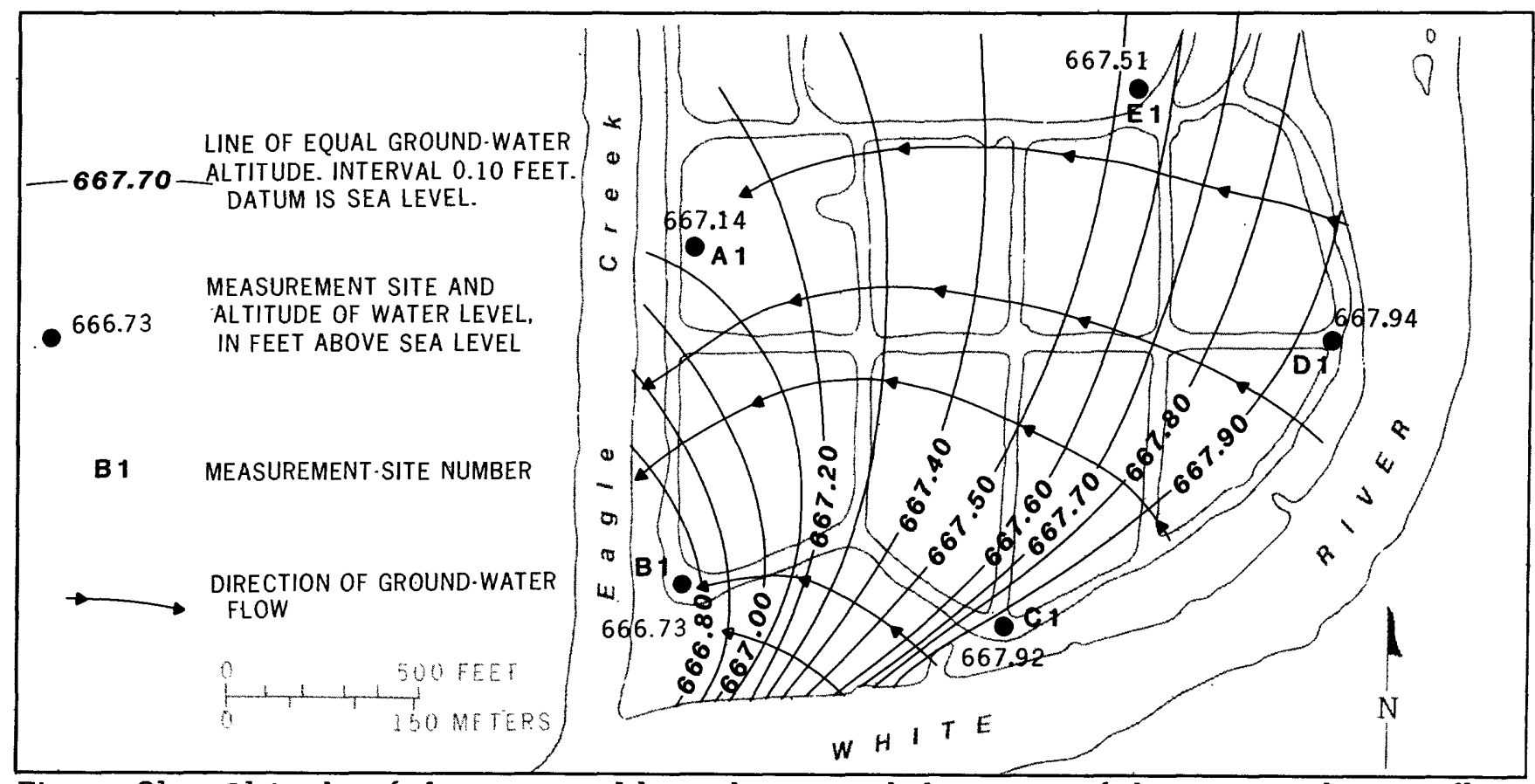

Figure 9b.-- Altitude of the water table and reversed direction of deep ground-water flow beneath the Belmont sludge lagoons, October 2, 1986. 
R. A. Pettijohn (U.S. Geological Survey, written commun., 1978) measured water levels in two deep wells screened beneath the lagoons, in addition to multiple sites just west of the Belmont AWT plant across Eagle Creek. The direction of deep ground-water flow was toward the northwest because of industrial pumpage; this direction is opposite from the natural direction of deep flow in the area. Thirteen wells within a $2-\mathrm{mi}$ radius of the lagoons have the capacity to withdraw approximately $28 \mathrm{Mgal} / \mathrm{d}$ (million gallons per day) from this aquifer (Indiana Department of Natural Resource, written commun., 1986).

The relation between surface-water levels, dally precipitation, and ground-water levels beneath the lagoons is shown in the hydrographs in figures $10,11,12$, and 13. Precipitation was measured by the National Weather Service at the Indianapolis International Airport, which is located approximately $4 \mathrm{mi}$ southwest of the Belmont plant. Downward vertical flow at well sites $A$ and $B$ is shown in figure 10. The bank-storage phenomenon is shown in figure 11 in early December 1986, mid-Apr11 1987, and early July 1987, as the level of the river exceeds the ground-water level at well site D. Also illustrated here is the hydrologic connection between the aquifer and the river, and the homogeneity of the aquifer as shown by the similarity between the shallow and deep ground-water levels and the levels in the White River. The slight upward vertical gradient at site $E$ is shown in figure 12.

The hydrologic connection between the White River and the ground water beneath the lagoons at we11 D2 also is shown in the hydrographs in figure 13. The altitude of the White River at Morris Street and the ground-water level at we11 D2 are plotted from continuous (15-minute interva1) recorders at each site. A comparison of the two hydrographs reveals an almost simultaneous rise before the first large peak on July 1,-1987. The subsequent fall and rise in the hydrographs show less than a 12-hr (hour) lag between fluctuations of the river stage and the ground-water level. Th1s graphical correlation indicates a high hydraulic conductivity and seepage rate between the river and ground water at site D. Although the river and ground-water levels are nearly identical at the beginning and end of the period, the river rises 2 to $3 \mathrm{ft}$ higher than the ground water rises in response to rain. Therefore, although the response time is similar between the river and ground water, the magnitude of the response is much greater in the river.

Very little vertical flow occurs between the screened intervals of the paired wells. Meyer and others (1975, p. 19) made aquifer tests in the shallow, unconfined glacial outwash of the White River that yielded a $1: 10$ vertical to lateral hydraulic-conductivity ratio. This ratio is typical of glacial-outwash material. The presence of a thick, semiconfining clay layer would decrease the ratio substantially. The aquifer beneath sites $C$ and $D$ is nearly homogeneous; deep and shallow water levels are typically within 0.01 to $0.03 \mathrm{ft}$. The gradient for downward vertical flow ranged from 0.0008 to 0.015 $\mathrm{ft} / \mathrm{ft}$ at site A, and from 0.0034 to $0.025 \mathrm{ft} / \mathrm{ft}$ at site B. Average gradients were $0.0058 \mathrm{ft} / \mathrm{ft}$ at well site $A$, and $0.014 \mathrm{ft} / \mathrm{ft}$ at well site $B$. At site $E$, average vertical gradient was $-0.0015 \mathrm{ft} / \mathrm{ft}$-that is, slightly upward. 

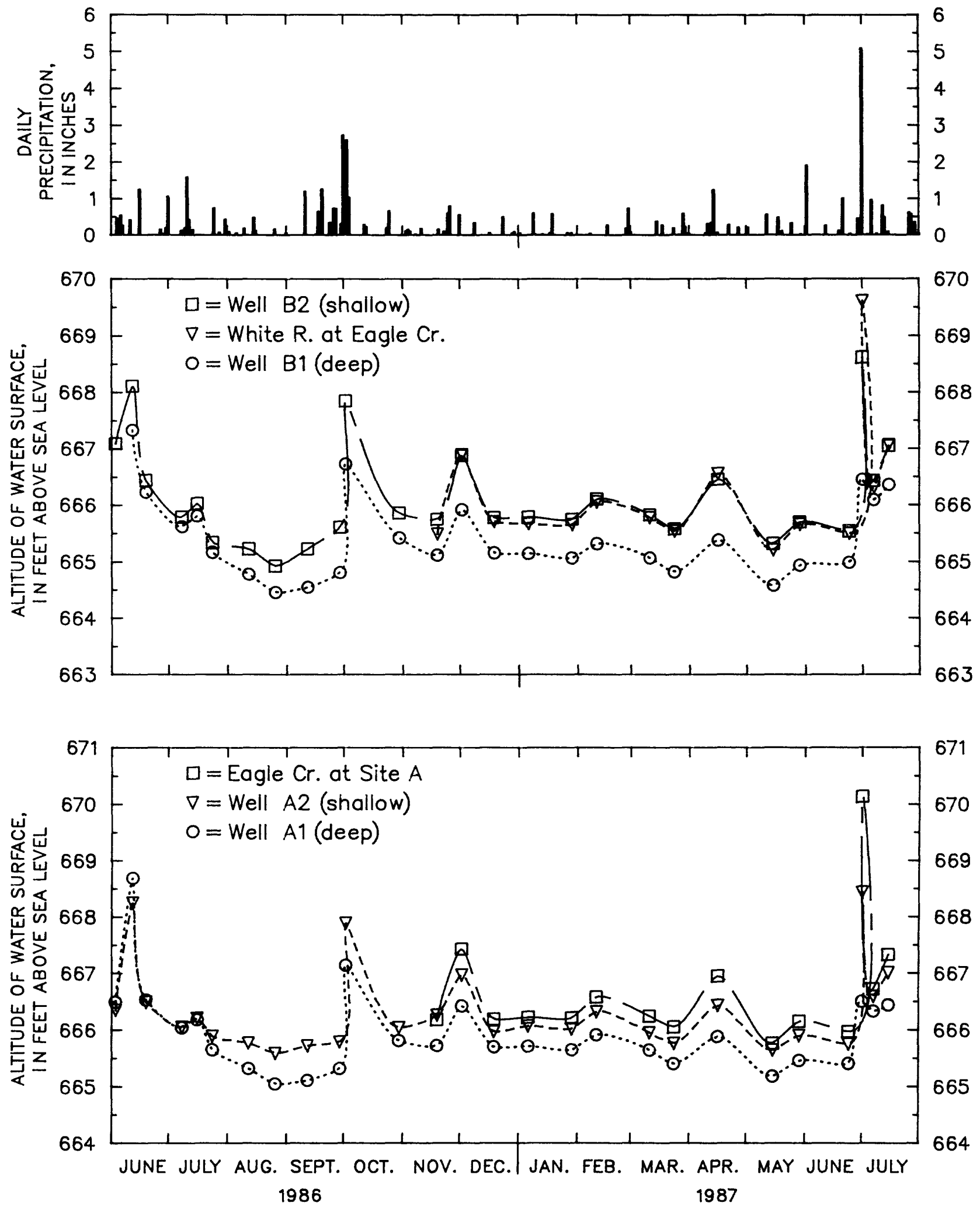

Figure 10.--Altitude of water surface near Belmont well sites $A$ and $B$, and daily precipitation, June 1986 through July 1987. 

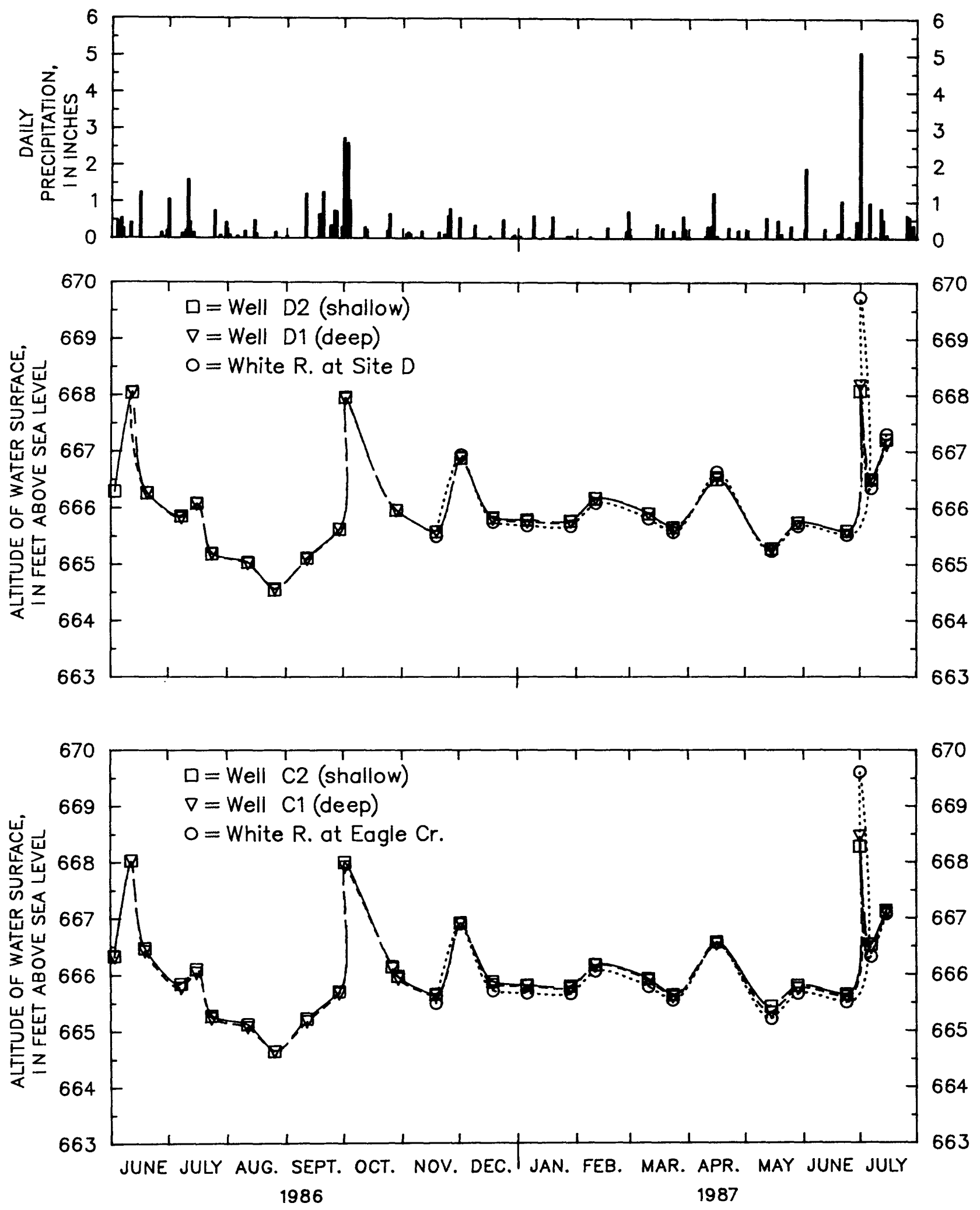

Figure 11.--Altitude of water surface near Belmont well sites $C$ and $D$, and daily precipitation, June 1986 through July 1987. 

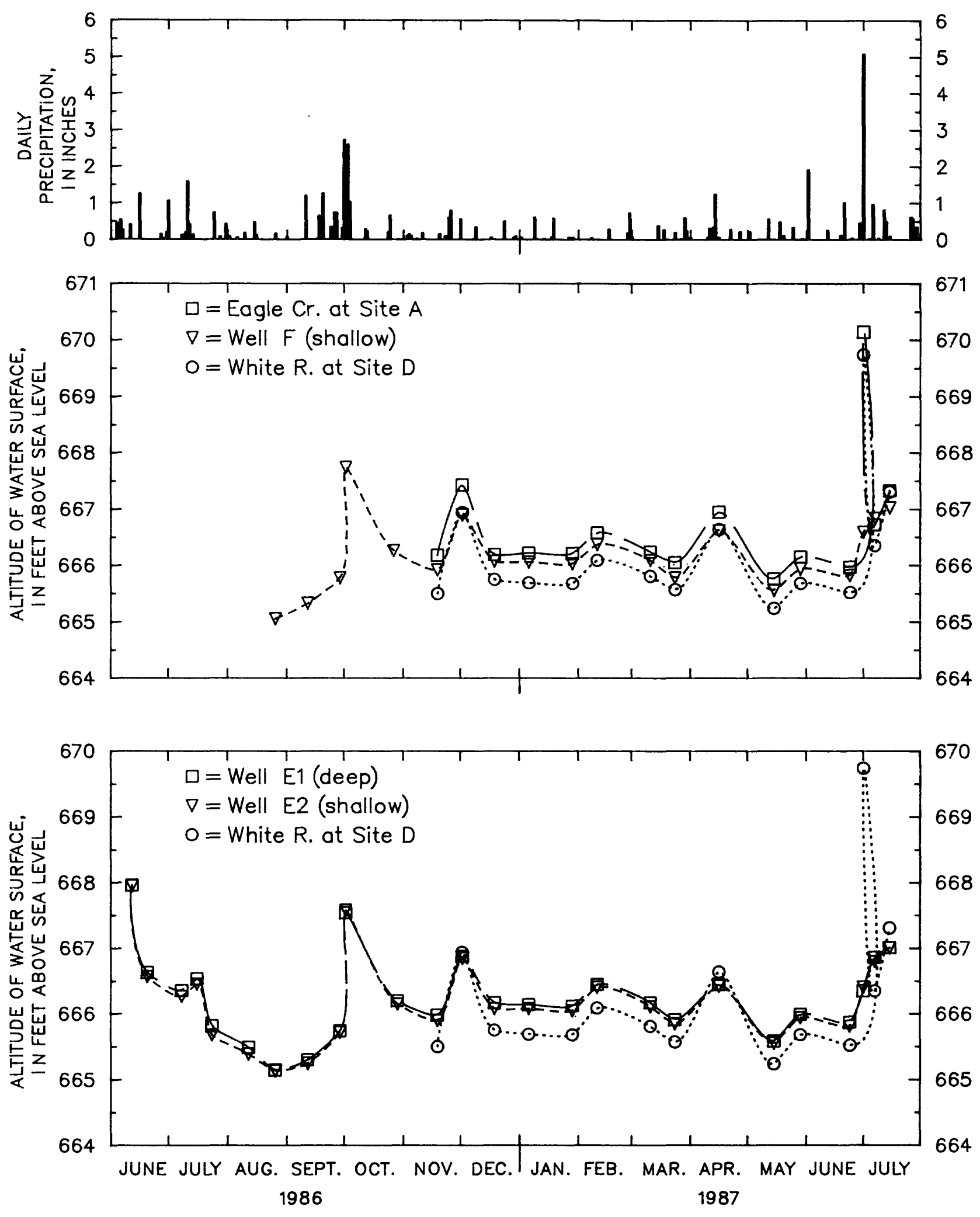

Figure 12.--Altitude of water surface near Belmont well sites $E$ and F, and daily precipitation, June 1986 through July 1987. 


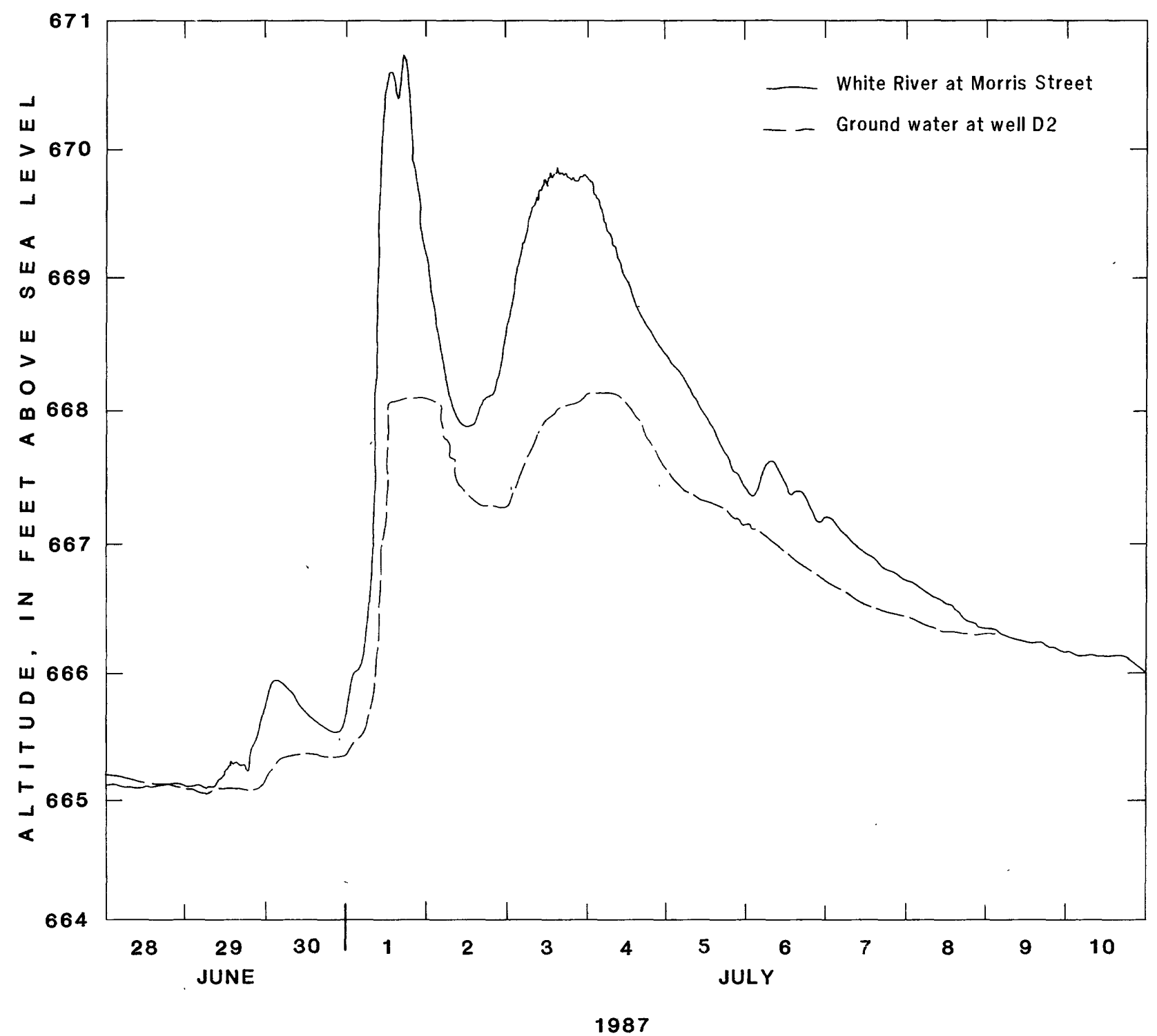

Figure 13.-- Altitude of White River at Morris Street and ground water at Belmont well D2, June 28 through July 10, 1987. 
Estimates of ground-water velocity were calculated by using a range of hydraulic-conductivity values from other studies in the area (Meyer and others, 1975, p. 18; Sm1th, 1983, p. 30; Bassett, J. L., Geosciences Research Associates, Inc., oral commun., 1988). At 25-percent porosity, average seepage rates from the ground water into the river range from 0.12 to $0.29 \mathrm{ft} / \mathrm{d}$ (feet per day) in the shallow aquifer using an average horizontal gradient of $0.0003 \mathrm{ft} / \mathrm{ft}$ and hydraulic-conductivity values of 100 and $240 \mathrm{ft} / \mathrm{d}$. Average seepage rates in the deeper aquifer range from 0.10 to $0.24 \mathrm{ft} / \mathrm{d}$, based on an average gradient of $0.0006 \mathrm{ft} / \mathrm{ft}$ and hydraulic-conductivity values of 40 and $100 \mathrm{ft} / \mathrm{d}$. Therefore, although the gradients are steeper in the deeper aquifer, seepage rates are slightly less because of the higher percentage of finegrained sediments that decrease horizontal and vertical hydraulic conductivity.

\section{QUALITY OF GROUND WATER BENEATH THE BELMONT SEWAGE-SLUDGE LAGOONS}

The quality of ground water in the glacial sand and gravel aquifers of Marion County varies greatly but can be summarized as a very hard, calcium bicarbonate-type water, with neutral to slightly alkaline pH. Shampine (1975, p. 78) and Cable and others (1971, p. 33) reported chemical analyses from more than 70 wells completed in the glaclal-outwash aquifer of the White River valley (table 7). Concentrations of iron, manganese, and DS typically exceed USEPA secondary drinking-water recommended limits established for aesthetic, nonhealth purposes (U.S. Environmental Protection Agency, 1982b).

Topics discussed in this section include factors that affect leachate migration, results of the chemical and biological analyses of ground water beneath the sludge lagoons and a comparison of the results with historical data from the glacial-outwash aquifer, and the spatial and temporal changes in ground-water quality beneath the lagoons. 

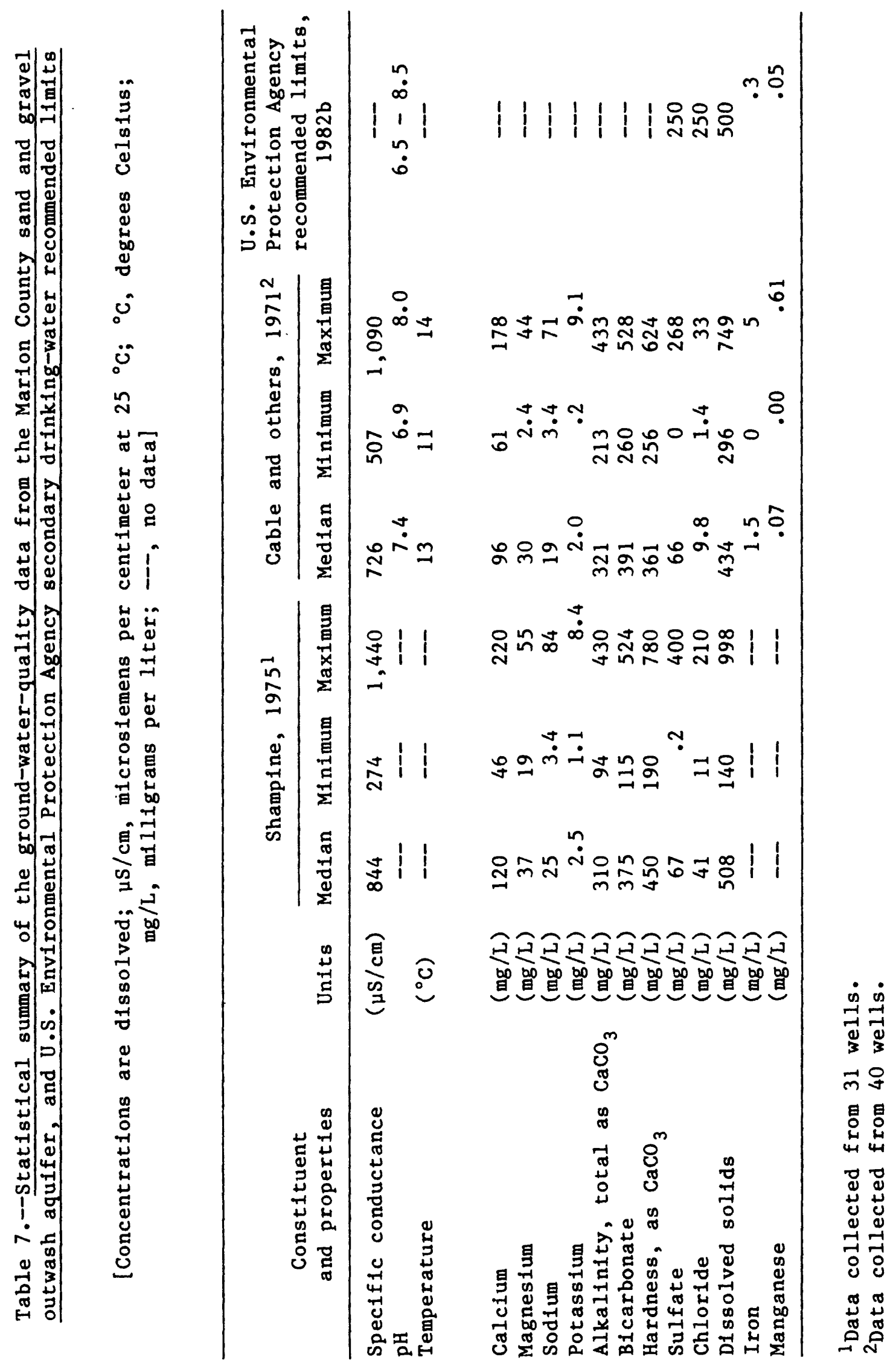


\section{Factors That Affect the Migration of Leachate in Ground Water}

The primary biogeochemical processes and reactions that affect the concentration of many constituents in ground water beneath sludge lagoons include decay of organic matter, precipitation and dissolution of minerals, sorption, ion exchange, gaseous generation and diffusion, and movement of dissolved spectes (Baedecker and Apgar, 1984, p. 128).

The rate at which leachate moves into and through a ground-water system is dependent on the quantity of infiltration, lateral inflow rate, natural and bioreduced transmissivity, hydraulic gradient, and local pumpage (Baedecker and Apgar, 1984, p. 129). The primary transport processes that involve solutes at waste-disposal sites are dilution and dispersion by lateral movement (Baedecker and Back, 1979b, p. 406). Maximum estimates of solute transport beneath the Belmont sludge lagoons can be calculated by assuming simple advective transport of a conservative constituent. Given the previous estimates of seepage rates beneath the lagoons, a constituent originating at shallow well A2 could take as much as $20 \mathrm{yr}$ to discharge to the White River. A constituent originating at deep well $\mathrm{El}$ would take nearly $40 \mathrm{yr}$ to discharge to the White River. Shallow ground water at sites B, C, and D have much less distance to travel and would discharge to the river in approximately $8 \mathrm{yr}, 3 \mathrm{yr}$, and $2 \mathrm{yr}$. These estimates assume that the effect from reversals on the overall advective transport are insignificant.

As previously stated in the section "Belmont Advanced WastewaterTreatment Plant and Sewage-Sludge Lagoons", lagoon no. 12 is lined with clay to retard the flow of leachate percolating from the lagoon. In addition to being a physical barrier, the liner also has the potential to be a chemical barrier because of its greater cation-exchange capacity compared to the underlying sand and gravel. The seven remaining lagoons lie directly on the outwash sand and gravel aquifer, which is quite permeable (figs. 6 and 7 ). But the flow of leachate through the lagoons can be retarded by decaying organic matter and bacterial-waste products that settle to the bottom and form a lowpermeability layer (Chang and others, 1974; Uebler and Swartzendruber, 1978; Baxter and Martin, 1982; Kehew and others, 1983). Hills (1976) determined that very little ground-water contamination existed beneath anaerobic waste lagoons in New Zealand. He estimated that only 1 percent of the wastewater infiltrates through the lagoon bottom, and that less than 1 percent of the potential pollutants are contained in the leachate.

In a laboratory, Chang and others (1974) simulated the retardation or sealing mechanism beneath wastewater ponds and the subsequent change in hydraulic conductivity. They determined that hydraulic-conductivity values in columns of sandy soll, loamy soll, and clayey soll decreased by as much as 99.7 percent after 3 mo (months) of submergence in wastewater. The soll texture did not affect the magnitude of the final hydraulic-conductivity value; texture only affected the amount of time necessary for the seal to form. Hydraulic-conductivity values of all three solls were less than $0.005 \mathrm{ft} / \mathrm{d}$ after submergence. Hills (1976, p. 704) also determined that there was very little difference in rates of infiltration between soil types once sealing progressed to a stable state. However, the quantity of pollutants that leach out of a waste pond before the seal takes effect is potentially significant. 
Preul (1968, p. 669) measured the infiltration rate through sandy soils beneath a waste-stabilization pond to be $0.01 \mathrm{ft} / \mathrm{d}$. Hills $(1976, \mathrm{p} .701)$ calculated infiltration rates beneath anaerobic waste lagoons and pilot-scale models to range from 0.0025 to $0.01 \mathrm{ft} / \mathrm{d}$. These rates are within an order of magnitude of the vertical hydraulic-conductivity values reported by Meyer and others (1975, p. 19) for the semiconfining clay layers in the White River valley.

Chang and others (1974), Hills (1976), and Uebler and Swartzendruber (1978) determined that the sealing mechanism beneath waste lagoons is the clogging of soil pores by physical and biological methods. An initial, temporary reduction of infiltration is attributed to physical clogging by suspended particles. Blological clogging that results from the growth of slime-forming organisms during prolonged submergence, and the excretions of microorganisms virtually seal off the soils and significantly reduce further infiltration to the ground water. The researchers noted that if the soils were no longer submerged, then the hydraulic conductivity returned to its value prior to submergence. Therefore, if sludge lagoons are not kept saturated, then a slug of concentrated pollutants initially will leach into the ground water beneath the lagoons and continue leaching until the source is depleted or until the sludge once again is submerged.

Physical conditions in the lagoons can affect the quality of water that leaches into the ground water. The saturated sludge in the Belmont lagoons maintains anaerobic conditions at the base of the lagoon. Therefore, the water that leaches through this base is in a reduced state. Nitrogen is maintained in the reduced ammonium form and iron in the soluble ferrous state. Conditions are not reducing enough to maintain low sulfate concentrations. Many trace metals are less soluble in this reducing environment.

The bottoms of the Belmont lagoons are approximately 2 to $5 \mathrm{ft}$ above the water table. Therefore, leachate from the lagoons must pass through an unsaturated zone before entering the ground-water system. Jewel1 (1983, p. 404) characterized the unsaturated zone as a significant component of the assimilation capacity-that is, the ability of the soils beneath lagoons to hold pollutants or to convert pollutants to an innocuous form. This zone is capable of transforming the carbonaceous and nitrogenous components of the leachate and of providing an oxidizing zone to precipitate phosphorus and certain heavy metals. It 18 uncertain whether the unsaturated zone beneath the Belmont lagoons is an oxidizing environment.

Another important characteristic of unsaturated zones is the ability to retain water and soluble pollutants in order for assimilative biogeochemical reactions to occur. Jewell (1983, p. 404) estimates that $3 \mathrm{ft}$ of unsaturated thickness beneath a lagoon would provide a 2-mo retention for approximately $6 \mathrm{in.} \mathrm{of} \mathrm{water} \mathrm{in} \mathrm{most} \mathrm{climates.} \mathrm{This} \mathrm{retention} \mathrm{time} \mathrm{is} \mathrm{responsible} \mathrm{for} \mathrm{high}$ removal percentages of certain constituents. However, at times of extremely high water levels, such as the 10-yr flood, the ground water and the lagoons will come into direct contact and the water levels will rise above the bottom of the Belmont sludge lagoons. This direct hydraulic connection with the lagoons also might affect the concentrations of certain chemicals leached from the lagoons. The significance of this phenomenon has not been quantified in this study. 


\section{Water-Quality Constituents}

Specific constituents were chosen for analysis in the current study to determine the gross chemical composition of the ground water, to indicate effects from the sludge lagoons, and to define the flow of ground water beneath the lagoons. Onsite measurements at the well sites consisted of temperature, $\mathrm{pH}, \mathrm{DO}$, and specific conductance. Calcium, magnesium, sodium, potassium, alkalinity, chloride, and sulfate were the major lons analyzed in water samples from wells beneath the lagoons. The nutrients analyzed included four forms of nitrogen plus total phosphorus. Fifteen metals and trace elements were included in the analysis. COD, total phenols, and MBAS were analyzed as indicators of organic constituents. Only the dissolved forms of all chemical constituents, except MBAS, were analyzed. Biological analyses included fecal collform, total coliform, and fecal streptococci bacteria.

\section{Onsite Analyses}

Onsite measurements of temperature, $\mathrm{pH}, \mathrm{DO}$, and specific conductance were made in a flow-thru chamber after the water had passed through the submersible pump and tubing. The ground water beneath the lagoons can be characterized as pH neutral, nearly devoid of oxygen, and as having moderate to high conductance. Median specific conductance values for shallow ground water ranged from 1,460 to $2,080 \mu \mathrm{S} / \mathrm{cm}$ (microsiemens per centimeter at 25 degrees Celsius); median range in the deeper ground water was 962 to $1,870 \mu \mathrm{S} / \mathrm{cm}$. Median $\mathrm{pH}$ in the ground water ranged from 6.82 in shallow well F to 7.54 in deep we11 $\mathrm{Bl}$. Median DO concentrations in water from seven we $11 \mathrm{~s}$ was $0.1 \mathrm{mg} / \mathrm{L}$. Water in wells $\mathrm{Cl}$ and $\mathrm{C2}$ contained slightly more oxygen; the median concentrations in well $\mathrm{Cl}$ was $0.3 \mathrm{mg} / \mathrm{L}$, and $0.45 \mathrm{mg} / \mathrm{L}$ in well $\mathrm{C} 2$. Water in both wells at site $\mathrm{E}$ had median DO concentrations of $0.0 \mathrm{mg} / \mathrm{L}$. Median temperature of the ground water ranged from $14.7{ }^{\circ} \mathrm{C}$ in deep well B1 to $19.2{ }^{\circ} \mathrm{C}$ in shallow well $\mathrm{C} 2$. Median air temperatures during each time of sampling were $88^{\circ} \mathrm{F}$ in July 1986 , $61{ }^{\circ} \mathrm{F}$ in October 1986, $30^{\circ} \mathrm{F}$ in January $1987,91{ }^{\circ} \mathrm{F}$ in May 1987, and $86^{\circ} \mathrm{F}$ in July 1987. Results of the water-quality analyses are summarized in tables 8 and 9.

The DO and $\mathrm{pH}$ seem to be the variables that control the ground-water quality beneath the lagoons. Low to nondetectable concentrations of DO result from the decomposition of organic matter in the sludge and the oxidation of metals to form oxides and hydroxides. Nearly neutral pH results from a number of chemical and biological reactions in the ground water. Much carbon dioxide is produced during the decomposition of organic matter and reacts with the ground water to form carbonic acid. The carbonic acid then dissociates to bicarbonate and hydrogen lons, which tends to reduce the $\mathrm{pH}$ of the ground water. These reactions apparently are balanced by the consumption of free hydrogen ions during ammonification and fermentation, which produce ammonium ions from ammonia and methane gas from carbon dioxide, and by the dissolution of calcite. Therefore, $\mathrm{pH}$ is controlled by the relative rates of bicarbonate, ammonium, and methane production and by calcite dissolution. Secondary processes that affect the $\mathrm{pH}$ of the system include the reduction of iron and manganese oxides and the exchange of hydrogen lons on clays (Baedecker and Back, 1979b, p. 397). 


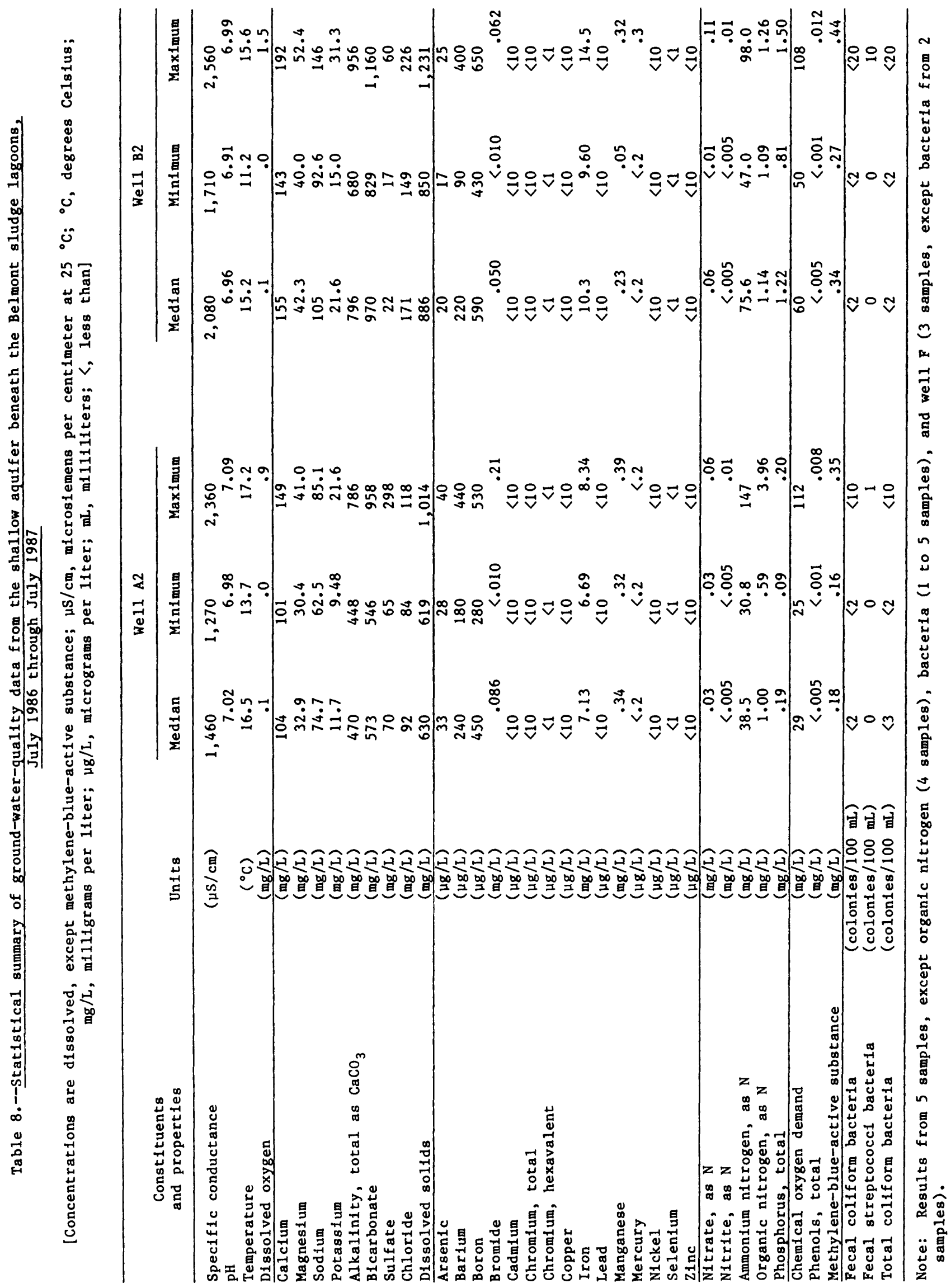




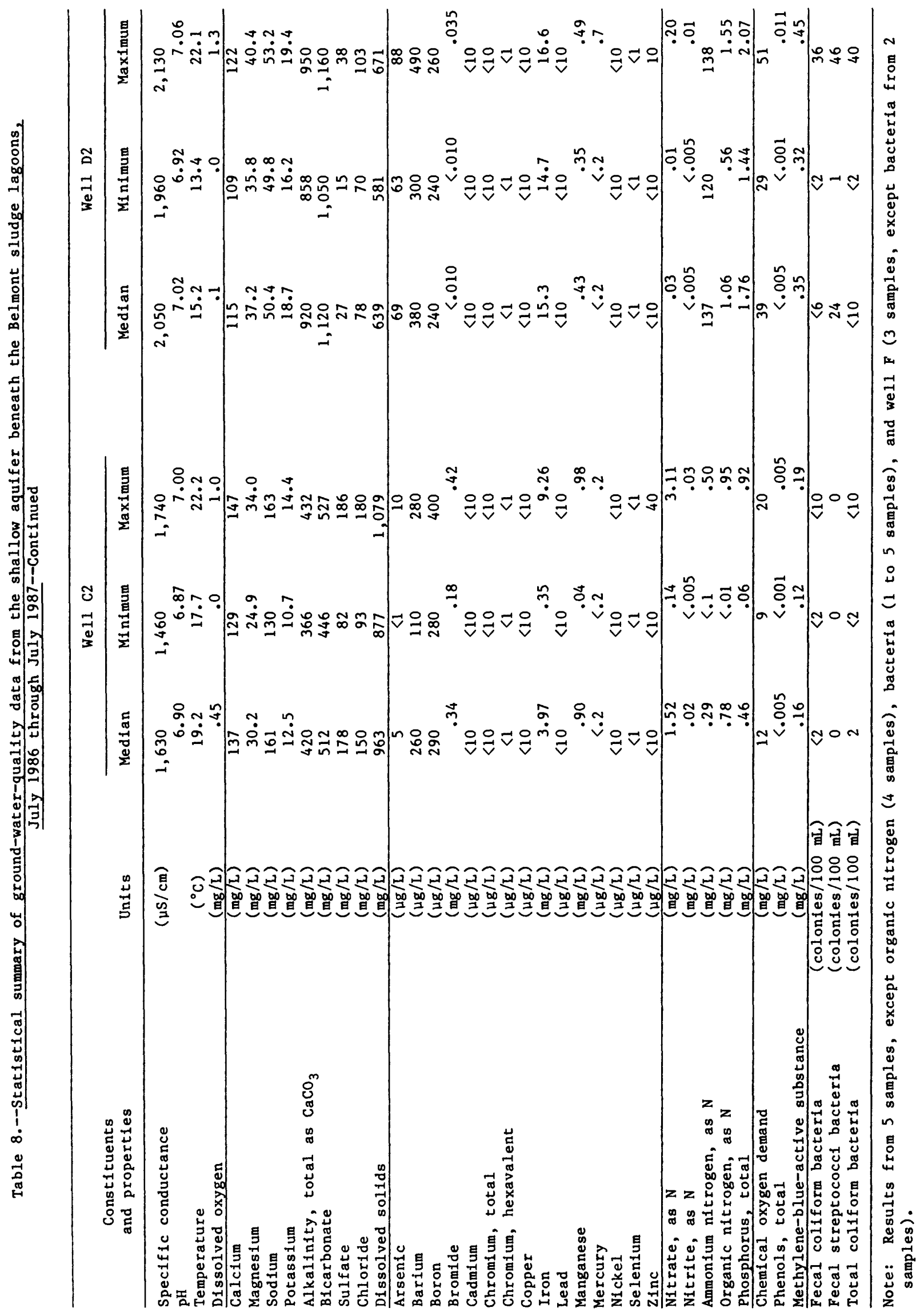




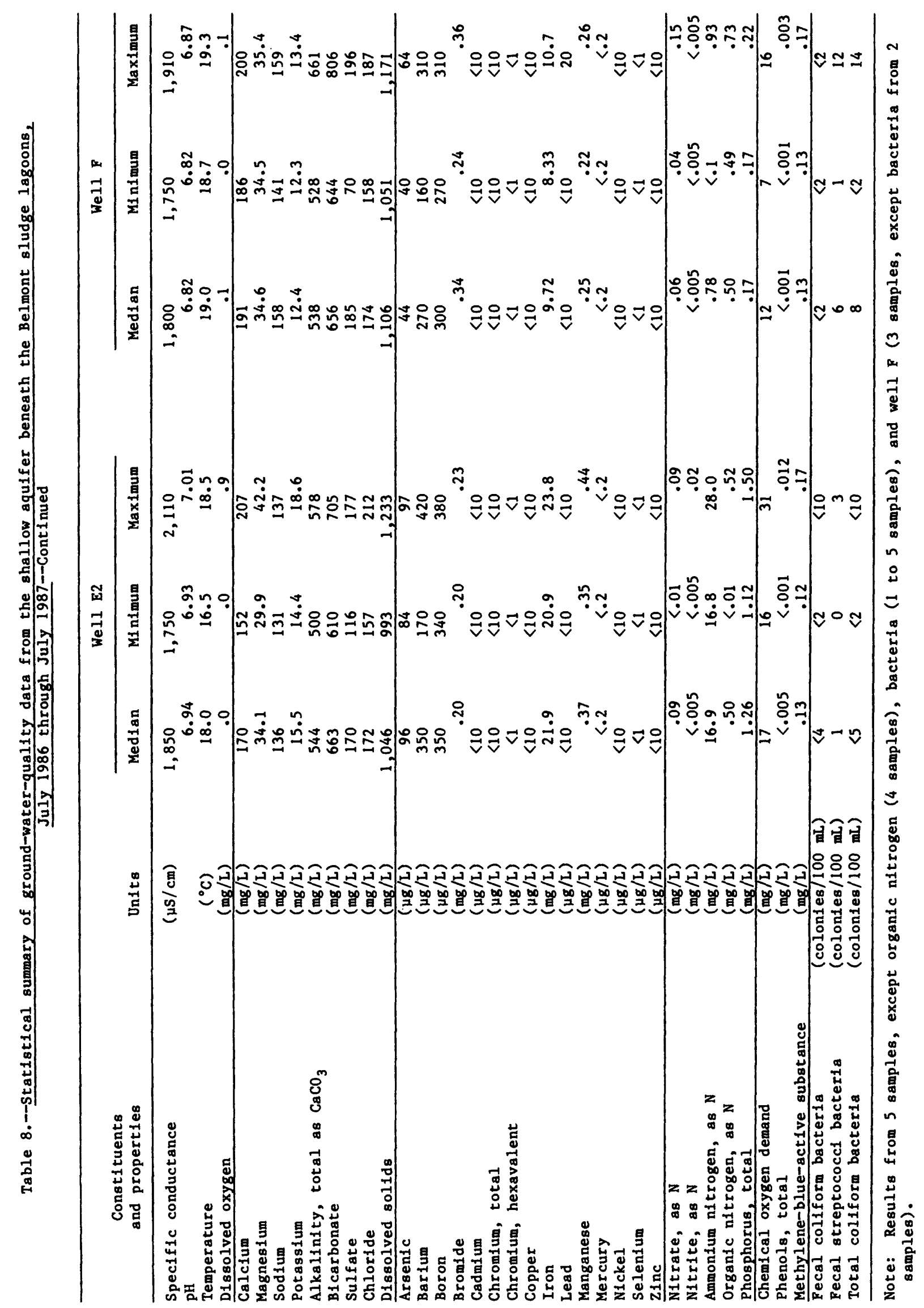




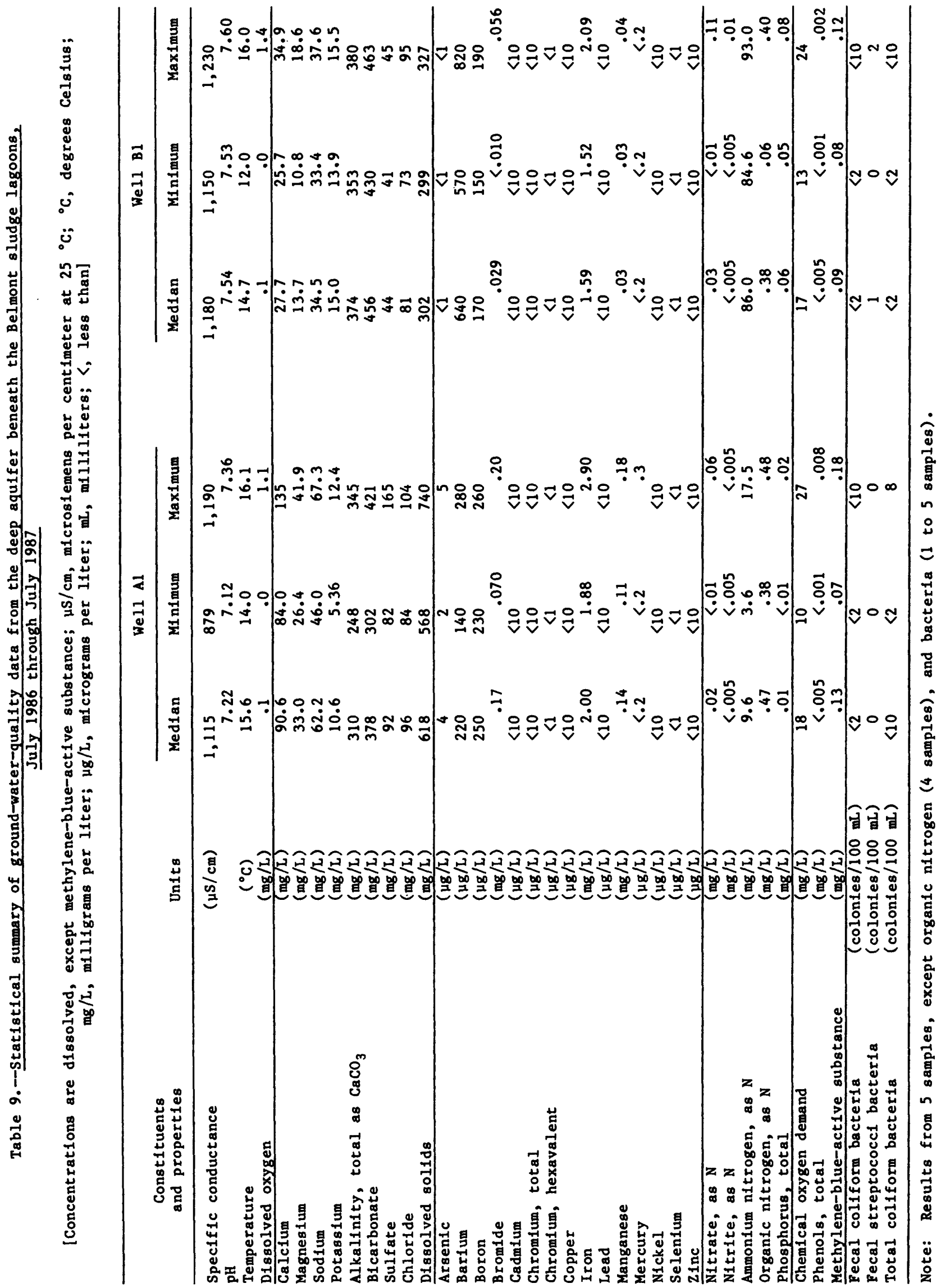




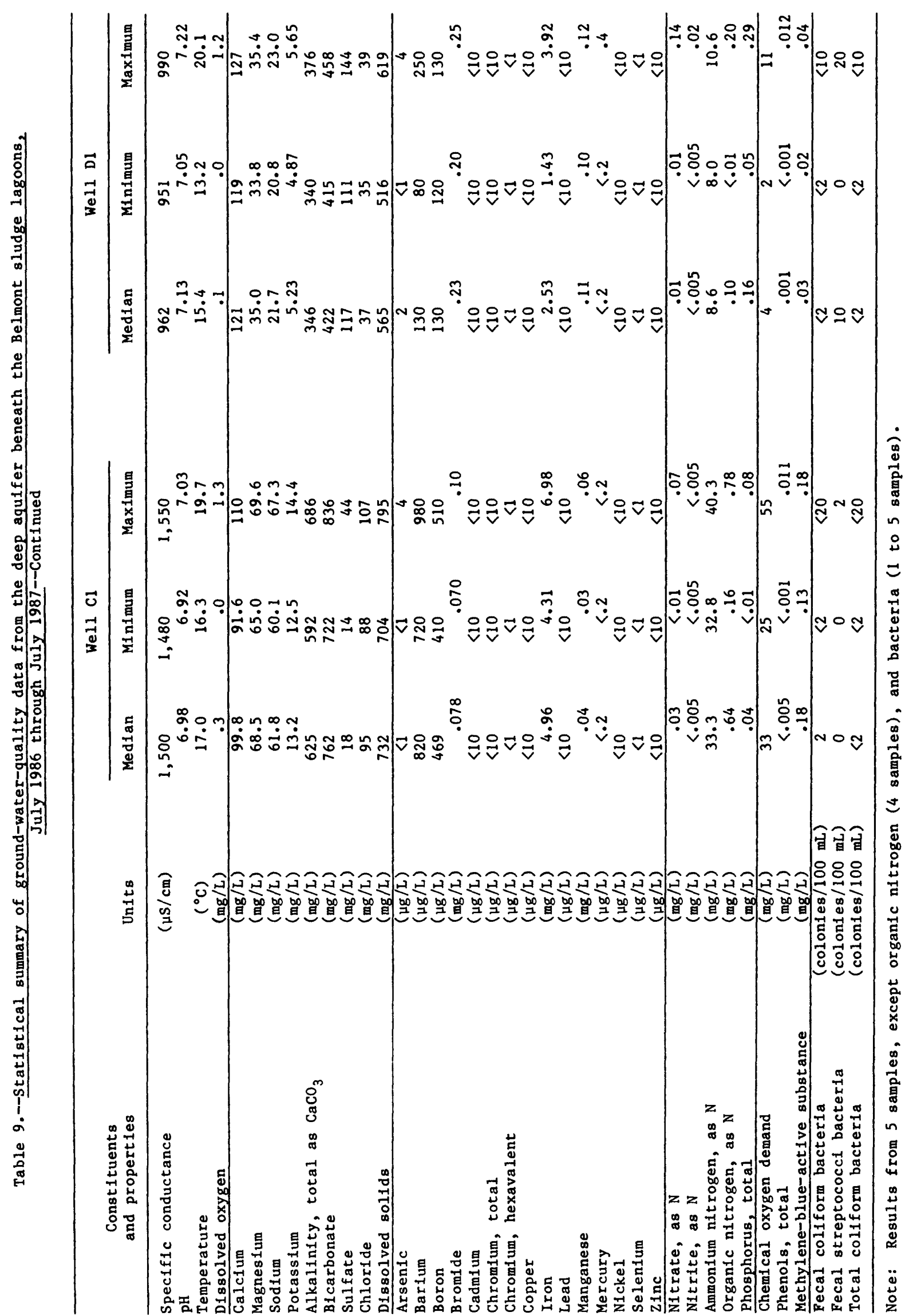




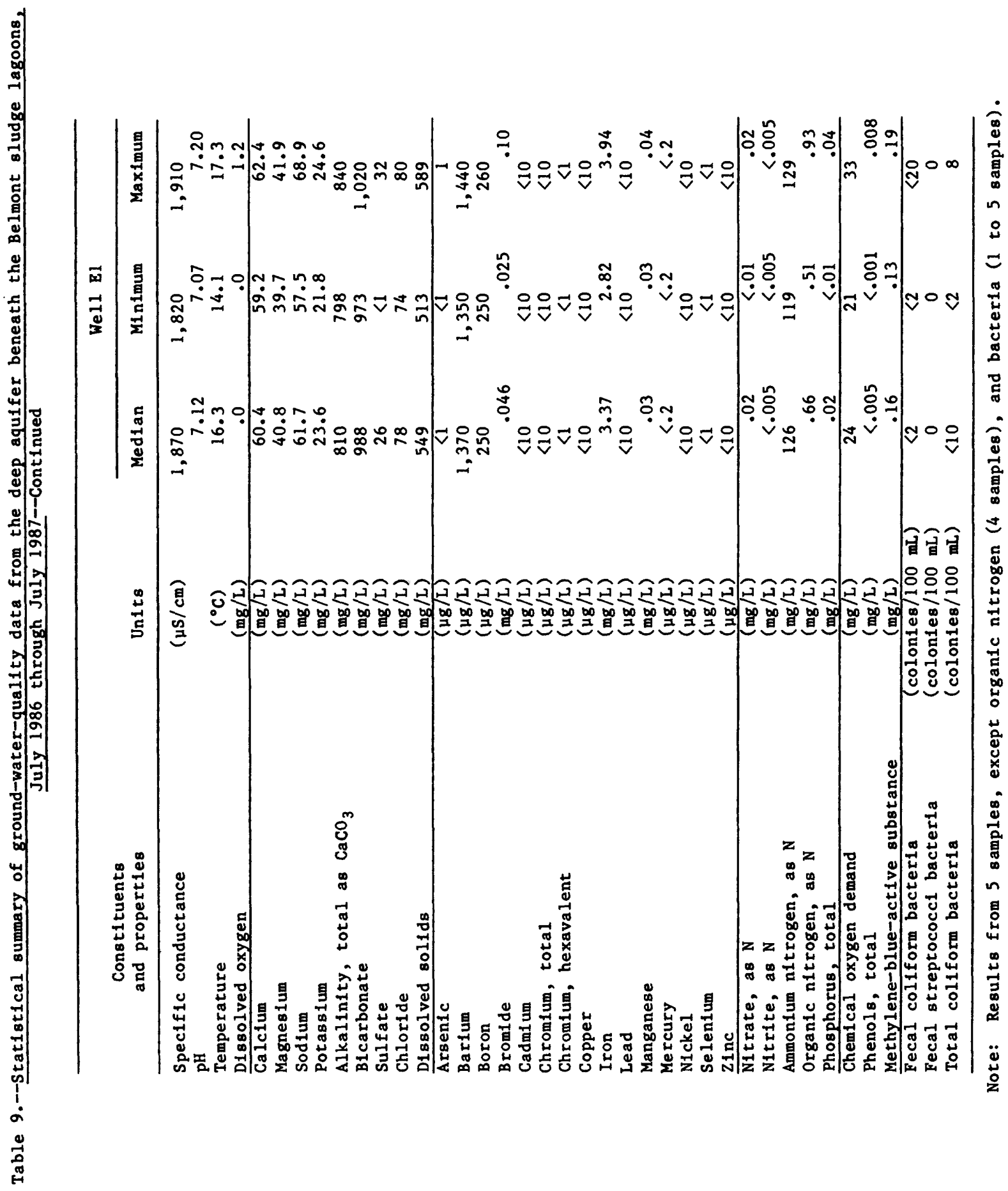


Water samples collected from wells beneath the lagoons were analyzed to characterize the major ionic composition of the ground water. The predominant water type is calcium bicarbonate, although ammonium is a major cation in water from three wells (that is, greater than or equal to 30 percent of total cation equivalents). Magnesium and sodium are prominent in the two wells at site C. Median concentrations of major lons in shallow and deep ground water are listed in tables 8 and 9. Water types are depicted in the Stiff diagrams in figure 14; concentrations of DS also are shown.

Six different water types from the 11 wells are shown in figure 14. Ground water in wells A1, A2, B2, and D1 is a calclum bicarbonate type, a1though ammonium was a major component of water in well A2 in July 1986. Ammonium replaces calcium as the dominant cation in water from wells B1, D2, and E1. Ammonium and calcium were codominant in ground water from well D2 in July 1986 and October 1986. We1ls C2, E2, and F typically contain calcium sodium bicarbonate-type water. Chloride was the codominant water type with b1carbonate in we11 C2 in October 1986 and in we11 E2 in July 1986. Water in well $\mathrm{Cl}$ consistently malntained magnesium at relatively high concentrations throughout the study; the water type on all sampling dates was magnesium calclum bicarbonate. The water types for all 11 wells were consistent in all three samples in 1987.

Because ammonium lons replace other monovalent and divalent cations (for example, calclum, magnesium, sodium, and potassium) on exchange sites, one of the major sources of cations in solution is exchange from clays and replacement by the ammonium contained in the leachate (Baedecker and Apgar, 1984, p. 133). Relatively high DS concentrations accompanied by low ammonium concentration in water from wells $\mathrm{Al}, \mathrm{C2}, \mathrm{D} 1, \mathrm{E} 2$, and $\mathrm{F}$ was indicative of this exchange process. The DS concentrations in shallow ground water were consistently greater than concentrations in deep ground water. The greatest differences between deep and shallow DS concentrations were in water at site $B$, where the thick clay layer is present, and at site $\mathrm{E}$, where a slight upward gradient exists. The highest DS concentrations were beneath the center of the lagoons in water from shallow wells C2, E2, and F. The lowest DS concentratlons were in water beneath the clay layer at well $\mathrm{Bl}$. 


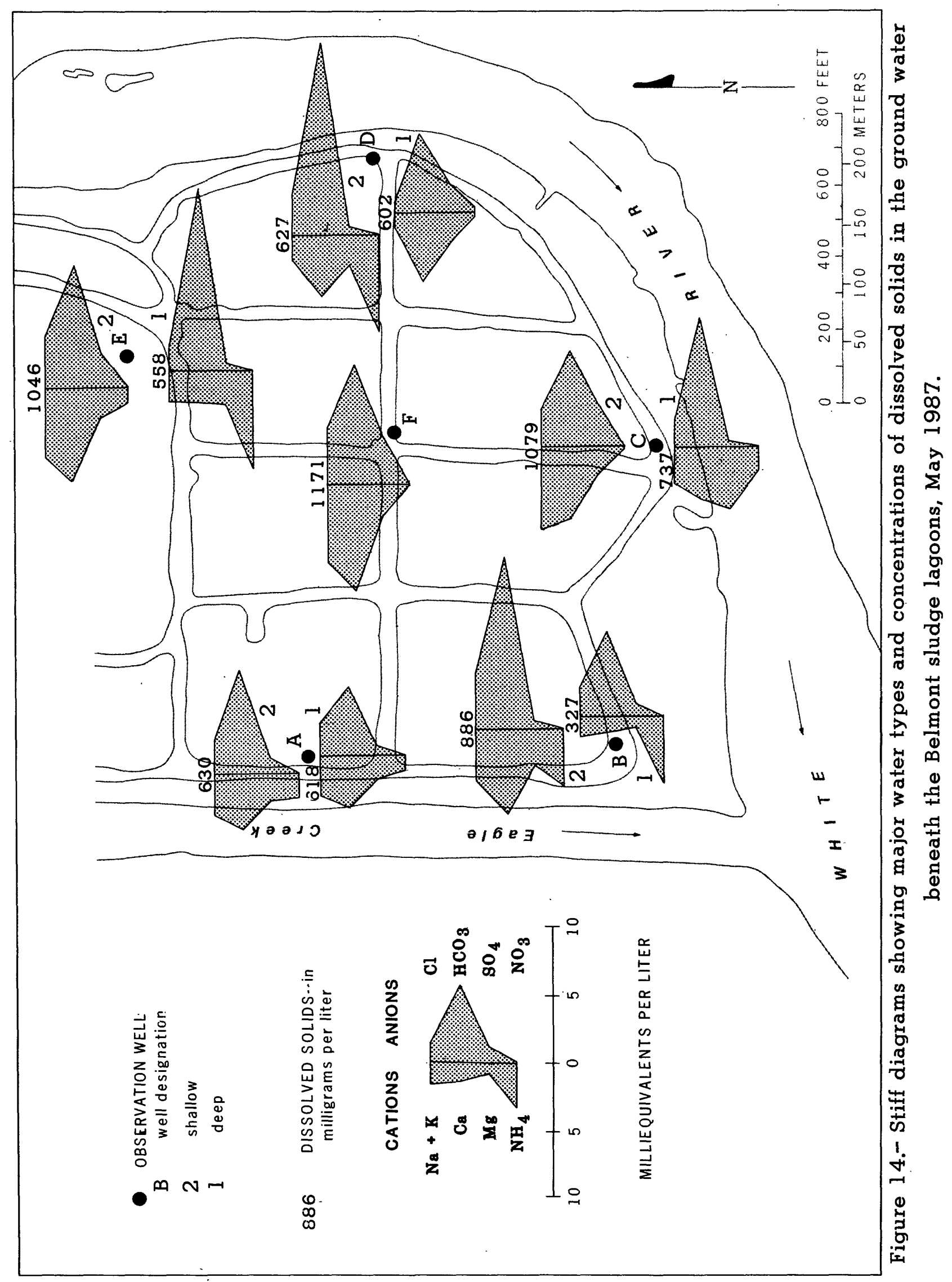


The presence of elevated concentrations of sodium and chloride in ground water in an otherwise low-sodium, low-chloride aquifer (Cable and others, 1971 , p. 33; Shampine, 1975, p. 78) Indicates leachate from a waste source or road salt (Legrand, 1968, p. 13-14). Median concentrations of sodium ranged from $21.7 \mathrm{mg} / \mathrm{L}$ in deep well D1 to $161 \mathrm{mg} / \mathrm{L}$ in shallow well C2. Only two wells had median concentrations less than $50 \mathrm{mg} / \mathrm{L}$. Median concentrations of chloride ranged from 78 to $174 \mathrm{mg} / \mathrm{L}$ in the shallow ground water, and from 37 to $96 \mathrm{mg} / \mathrm{L}$ in the deep ground water. The median value reported by Shampine (1975, p. 33) for 31 wells was $41 \mathrm{mg} / \mathrm{L}$. Chloride is a conservative constituent because it generally is not affected by biological and chemical reactions; therefore, it of ten is used to trace a leachate plume that contains chloride. However, no plume could be delineated in the direction of groundwater flow beneath the lagoons because (1) concentrations are diluted and dispersed in the aquifer, (2) ground-water velocities are very slow, (3) the concentrations of solutes vary within and among the lagoons, (4) flow direction is subject to temporary reversals, and (5) the wells are few in number and widely spaced. Russell and others (1987, p. 864) determined that slow rates of ground-water flow restrict the areal distribution of leachate, and make plumes very difficult to detect.

Sulfate concentrations in ground water beneath the lagoons varied considerably; medians ranged from $18 \mathrm{mg} / \mathrm{L}$ at $\mathrm{Cl}$ to $185 \mathrm{mg} / \mathrm{L}$ at $\mathrm{F}$. Median concentrations of sulfate in shallow ground water from wells C2, E2, and F were nearly three times greater than median concentrations found in the Marion County sand and gravel outwash aquifer (Shampine 1975, p. 78; Cable and others 1971, p. 33). Sulfate concentrations can be affected by reduction-oxidation conditions in the aquifer and by complexation with cations. During decomposition of organic compounds such as fatty acids, amino acids, and carbohydrates, sulfate is reduced to sulfide in the absence of molecular oxygen (Baedecker and Back, 1979b, p. 395). The large difference in median sulfate concentrations (144 mg/L) between shallow and deep ground water at site $\mathrm{E}$ probably is because of the reduction of sulfate to sulfide with depth.

\section{Nutrients}

Total phosphorus and four forms of nitrogen (ammonium, nitrate, nitrite, and organic) were analyzed from samples of the ground water beneath the lagoons. Phosphorus is easily attenuated by sorption and biotic uptake. Total phosphorus concentrations generally are less than a few milligrams per liter in natural ground water (Hem, 1985, p. 128). Water in all of the shallow wells and in deep well D1 contained detectable levels of phosphorus; the maximum median concentration was $1.76 \mathrm{mg} / \mathrm{L}$ at well D2. Ammonium was the dominant form of nitrogen in water from 9 of the 11 wells; median concentrations ranged from $0.29 \mathrm{mg} / \mathrm{L}$ at well C2 to $137 \mathrm{mg} / \mathrm{L}$ at D2 (tables 8 and 9). High ammonium concentrations are indicative of reducing conditions and saturated exchange sites on clay minerals. The median ammonium nitrogen concentration for the ground-water system was $33.0 \mathrm{mg} / \mathrm{L}$. The sludge lagoons are the most probable source of these high ammonium concentrations, although adjacent landfills and fertilizer-storage facilities also may contribute to high ammonium concentrations in the area. Nitrate nitrogen was the dominant form only in 
water from well $\mathrm{C} 2$, near the ground-water discharge point. Dissolved-oxygen concentrations also were higher in water from well C2 than in other wells, which indicates that nitrification is occurring. Concentrations of nitrite nitrogen were not found in excess of the detection limit of $5 \mu \mathrm{g} / \mathrm{L}$ in 80 percent of all samples. Organic nitrogen typically ranged from less than 1 percent to nearly 10 percent of the total nitrogen. Organic was the codominant form of nitrogen with ammonium only in water from well F.

Ammonium nitrogen results from the mineralization of organic nitrogen produced during the decomposition of organic matter in the sludge. Ammonium nitrogen is very soluble in water, but concentrations are limited by nitrification under aerobic conditions and by adsorption. As stated earlier in the section, "Major Ions", the Ionic form $\left(\mathrm{NH}_{4}{ }^{+}\right)$exhibits a strong tendency to replace monovalent and divalent cations on exchange sites (Water Quality Division Committee on Nutrients in Water, 1970, p. 129-130).

Preul (1968, p. 664-667) attributed the advance of an ammonium front beneath municipal wastewater ponds to the saturation of cation-exchange sites. Estimates of the time required for the ammonium front to move $10 \mathrm{ft}$ through Hayden silt was $16.7 \mathrm{yr}$ and $5.0 \mathrm{yr}$ for Zimmerman (medium) sand. These estimates were based on assumed inftial concentration of $15 \mathrm{mg} / \mathrm{L}$ ammonium nitrogen and hydraulic conductivity of $0.01 \mathrm{ft} / \mathrm{d}$. Baedecker and Back (1979a, p. 431) used a nitrogen ratio, TKN: (nitrite plus nitrate), to delineate redox zones as leachate migrated beneath a landfill. Ratios beneath the Belmont lagoons typically were in excess of 1,000 , which indicates very reduced conditions. Only at well $\mathrm{C} 2$ are ratios low enough to indicate oxidizing conditions. The combination of low ammonium, high nitrate, and increased Do concentrations in water from we11 C2 compared to other wells implies that nitrification is occurring in the shallow ground water. The reducing conditions at the remaining sites are limiting the nitrifying bacterla necessary for nitrification to occur.

The two-step nitrification process can be summarized by:

$$
2 \mathrm{NH}_{4}^{+}+4 \mathrm{O}_{2} \longrightarrow-\longrightarrow 2 \mathrm{NO}_{3}^{-}+4 \mathrm{H}^{+}+2 \mathrm{H}_{2} \mathrm{O} \text {, }
$$

where 2 moles of ammonium ion combine with oxygen to form 2 moles of nitrate, plus hydrogen ions and water. The process is catalyzed by aerobic nitrifying bacteria (Wang and Reed, 1983, p. 3).

Concentrations of nitrate, as nitrogen, in the ground water beneath the Belmont lagoons ranged from a minimum of less than $0.01 \mathrm{mg} / \mathrm{L}$ at six we $11 \mathrm{~s}$ to a maximum of $3.11 \mathrm{mg} / \mathrm{L}$ at well $\mathrm{C} 2$. The USEPA primary drinking-water regulation for nitrate is $10 \mathrm{mg} / \mathrm{L}$ as nitrogen (U.S. Environmental Protection Agency, 1982a).

Apparently, nitrogen is being discharged to the river in the reduced ammonium form from sites other than $C$. Therefore, the ammonium nitrogen beneath the lagoons that discharges to the White River, will undergo nitrification, and produce nitrate nitrogen. 
D. J. Wangsness and C. G. Crawford (U.S. Geological Survey, written commun., 1986) reported an influx of approximately $400 \mathrm{lb}$ (pounds) of ammonium per day to the White River near the sludge lagoons in 1983, and $8001 \mathrm{~b} /$ day (pounds per day) in 1984. As previously stated, the lagoons are but one of a number of possible sources of ammonium to the river in the immediate area. Increased concentrations of nitrate and decreased concentrations of ammonium in the downstream direction indicated that nitrification was occurring in the White River during the study.

Median concentrations of ammonium nitrogen in the ground water near discharge areas beneath the lagoons were $75.6 \mathrm{mg} / \mathrm{L}$ at we11 B2, $0.29 \mathrm{mg} / \mathrm{L}$ at we11 $\mathrm{C} 2$, and $137 \mathrm{mg} / \mathrm{L}$ at well D2. By assuming an average concentration of $71 \mathrm{mg} / \mathrm{L}$ seeping into the White River at 2.0 to 4.1 cubic feet per second per mile (Smith, 1983, p. 22), a loading of 200 to 400 lb of ammonium nitrogen per day can be attributed to the ground water from beneath the lagoons. This could account for all of the ammonium influx detected in the White River by $D$. J. Wangsness and C. G. Crawford (U.S. Geological Survey, written commun., 1986) in 1983, and half of the influx detected in 1984.

Although total ammonia includes the un-ionized (ammonia nitrogen) and the ionized (ammonium nitrogen) forms, the concentration of un-ionized ammonia expected in these near-neutral $\mathrm{pH}$ waters is only about 0.25 percent of the total (U.S. Environmental Protection Agency, 1986; U.S. Environmental Protection Agency, 1976, p. 18). This is very important because un-1onized ammonia is the toxic form; the lonized form has little or no toxicity to aquatic life (U.S. Environmental Protection Agency, 1976, p. 18). Even though the toxic form accounts for only a small percentage of the total, the ammonium nitrogen concentrations beneath the lagoons often exceed the USEPA recommended waterquality criterion for freshwater aquatic organisms (U.S. Environmenta1 Protection Agency, 1986).

In 1976, the recommended criterion for freshwater aquatic life was $0.02 \mathrm{mg} / \mathrm{L}$ as ammonia. This is approximately equal to $7.3 \mathrm{mg} / \mathrm{L}$ total ammonia at $\mathrm{pH} 7$ and $15{ }^{\circ} \mathrm{C}$ (U.S. Environmental Protection Agency, 1976, p. 16). The revised 1986 critertion is based on a formula that includes $\mathrm{pH}$ and temperature, because ammonia toxicity increases as $\mathrm{pH}$ and temperature decrease. At $\mathrm{pH} 7$ and $15{ }^{\circ} \mathrm{C}$, the equivalent 4-day average concentration not to be exceeded once every $3 \mathrm{yr} 1 \mathrm{~s} 1.81 \mathrm{mg} / \mathrm{L}$ total ammonia nitrogen. The $1-\mathrm{hr}$ average criterion is $19.7 \mathrm{mg} / \mathrm{L}$ total ammonia nitrogen (U.S. Environmental Protection Agency, 1986). These surface-water-quality criteria are compared to the ground-water concentrations detected beneath the lagoons because the ammonium nitrogen is entering the surface water by ground-water discharge. The 4-day average, considered a chronic criterion, was exceeded in water from 9 of the 11 wells at the Belmont lagoons; the 1-hr criterion (acute) was exceeded in ground water from 7 we1ls. 
Metals and Trace Elements

Metals and trace elements are found often in wastewater sludge and in ground water beneath sewage-sludge lagoons, especially in industrialized areas. Municipal sludge can be enriched with potentially harmful metals because they are concentrated in the sludge fraction during wastewater treatment (Page and Chang, 1983, p. 50). Most of these metals are primarily in the solid phase. Although total concentrations in sewage sludge may be greater than $1,000 \mathrm{mg} / \mathrm{kg}$ (table 5), soluble metals often are less than $5 \mathrm{mg} / \mathrm{L}$ (Sommers, 1977, p. 229). The following metals and trace elements were analyzed in the ground-water samples beneath the Belmont lagoons: arsenic, barium, boron, bromide, cadmium, total chromium, hexavalent chromium, copper, iron, lead, manganese, mercury, nickel, selenium, and zinc. Many of the concentrations are less than the detection limits (tables 8 and 9).

Onsite studies have indicated that trace metals typically are not mobile in most neutral ground water (Cherry and others, 1984, p. 62). Exceptions are hexavalent chromium and selenium, which require an oxidizing environment as well as neutral pH. Sorption, complexation, solubility constraints, and cation exchange account for the immobility of trace metals. Gibb and Cartwright (1982, p. 37, 44) determined that cation exchange and precipitation of insoluble metal compounds were the primary mechanisms that control the mobility of metals in ground water, although transport rates are species specific. As the cation-exchange capacity of the sediments is exhausted, metal-rich water advances along the ground-water flow path. Calcium and magnesium are released from the solls until a point along the flow path is reached where the cation-exchange sites are not full. At this point, pH begins to increase and trace metals precipitate from the metal-rich water. Therefore, $\mathrm{pH}$ controls the maximum concentration of metals in solution. Iron and manganese also can be important in controlling the concentrations of other transition metals, because their oxides sorb and coprecipitate these metals in an oxidizing environment (Baedecker and Back, 1979b, p. 405). The reduction and dissolution of these oxides potentially can release iron, manganese, and other transition metals into solution.

Griffin and others (1977, p. 25, 33) reported that precipitation of the cationic forms of cadmium, copper, chromium, mercury, lead, and zinc was the most important attenuating mechanism at $\mathrm{pH}$ values greater than 7 . The authors also noted that these cations can be strongly attenuated by even small quantities of clay at lower values of $\mathrm{pH}$. Heavy metal anions (for example, arsenic and selenium species and hexavalent chromium) typically do not precipitate in near-neutral pH water. Precipitation and volatilization account for low to nondetectable concentrations of mercury. These authors also concluded that $\mathrm{pH}$ has a pronounced effect on heavy-metal concentrations in landfill leachates, and that the primary mechanism is ion exchange on clay minerals.

Arsenic was found in shallow ground water from we11s D2 and E2 at the Belmont lagoons on all five dates at concentrations in excess of $50 \mu g / \mathrm{L}$, which is the national interim primary drinking-water regulation for human health (U.S. Environmental Protection Agency, 1982a). Median concentrations of arsenic ranged from less than $1 \mu \mathrm{g} / \mathrm{L}$ in water from three deep wells to $96 \mu \mathrm{g} / \mathrm{L}$ at shallow well E2. Arsenic typically does not reach the deep 
aquifer. Low concentrations are maintained by adsorption in reducing environments, by coprecipitation, and by combination with sulfides in very reduced sediments. However, the solubility of arsenic compounds in natural water is high enough to maintain dissolved concentrations in excess of the drinkingwater regulations (Hem, 1985, p. 421). Kehew and others (1983, p. 39) determined that arsenic behaves similarly to iron beneath waste lagoons. They reported that reduced ground water releases arsenic from precipitated grain coatings and increases the solubility of arsenic-bearing compounds.

The valence of a metal commonly is more important than the total concentration of the metal in ground water. The toxicity of arsenic varies with the valence that is present: $A s(V)$ is the stable form in oxidized waters, whereas As(III) is a more toxic form that exists in moderately reducing environments, such as the ground water beneath the sludge lagoons (the numeral in parentheses refers to the valence or oxidation state). As ground water discharges to the White River, it presumably becomes oxidized to the less toxic and less soluble form, As(V). Not enough data are available to establish national water-quality criterion for this form of arsenic. However, As(V) has been determined to be acutely toxic to aquatic animals at concentrations greater than $850 \mu \mathrm{g} / \mathrm{L} ; \mathrm{As}(\mathrm{V})$ has affected aquatic plants at concentrations greater than $48 \mu \mathrm{g} / \mathrm{L}$ (U.S. Environmental Protection Agency, 1986).

Barium concentrations, normally controlled by the solubility of barite, are as much as four times higher in water from some deep wells at the Belmont lagoons (for example, wells $\mathrm{Cl}$ and $\mathrm{E} 1$ ) compared to the paired shallow wells. Sulfate concentrations in these same shallow wells are as much as 10 times higher than in the deep wells. Elevated sulfate concentrations tend to suppress barium solubility (Hem, 1985, p. 116). Median concentrations of barium ranged from 130 to $1,370 \mu \mathrm{g} / \mathrm{L}$ in deep ground water and from 220 to $380 \mu \mathrm{g} / \mathrm{L}$ in shallow ground water. The national interim primary drinking-water regulation of $1 \mathrm{mg} / \mathrm{L} \cdot(1,000 \mu \mathrm{g} / \mathrm{L})$ for barium (U.S. Environmental Protection Agency, 1982a) was exceeded on all five sampling dates at well El.

Boron, which is transported without substantial retardation, is indicative of a waste source at concentrations greater than a few tenths of a milligram per liter (Hem, 1985, p. 129; LeBlanc, 1984, p. 13). Median concentrations of boron ranged from 130 to $590 \mu \mathrm{g} / \mathrm{L}$ beneath the lagoons. Median concentrations greater than or equal to $300 \mu \mathrm{g} / \mathrm{L}$ were analyzed in water from four shallow wells and one deep well; therefore, boron may be leaching from the sludge lagoons into the ground water. Median bromide concentrations in the ground water ranged from less than the detection 1 imit of $0.01 \mathrm{mg} / \mathrm{L}$ at well D2 to $0.34 \mathrm{mg} / \mathrm{L}$ at well $\mathrm{C} 2$. Cadmium, total chromium, copper, and nickel were not detected in excess of the $10 \mathrm{\mu g} / \mathrm{L}$ analytical 1imit in the ground water beneath the lagoons. Hexavalent chromium and selenium were not detected in excess of the $1 \mathrm{\mu g} / \mathrm{L}$ 1imit. The neutral, reduced environment causes the relative insolubility of most metals and trace elements beneath the sludge lagoons.

The USEPA secondary drinking-water recommended 1 imits of $0.3 \mathrm{mg} / \mathrm{L}$ for iron and $0.05 \mathrm{mg} / \mathrm{L}$ for manganese (U.S. Environmental Protection Agency, 1982b) were exceeded in water from almost all the wells beneath the sludge lagoons. Ground water in the study area has natural concentrations of iron in excess of the standard because of the mobilization of ferric-oxide cements in clays and sands. Median dissolved-iron concentrations in the ground water ranged from 
$1.59 \mathrm{mg} / \mathrm{L}$ at well B1 to $21.9 \mathrm{mg} / \mathrm{L}$ at well E2. Median concentrations of iron in ground water from all 11 wells were greater than the median concentration $(1.5 \mathrm{mg} / \mathrm{L}$ ) from the Marion County outwash aquifer (Cable and others, 1971). Naturally elevated manganese concentrations can result from the reduction and dissolution of manganese-bearing minerals. Median concentrations ranged from $0.03 \mathrm{mg} / \mathrm{L}$ at wells $\mathrm{B} 1$ and $\mathrm{E} 1$ to $0.90 \mathrm{mg} / \mathrm{L}$ at well $\mathrm{C} 2$. The median concentration of manganese in the outwash aquifer was $0.07 \mathrm{mg} / \mathrm{L}$ (Cable and others, 1971).

Lead was detected at a concentration of $20 \mu \mathrm{g} / \mathrm{L}$ in water from well $\mathrm{F}$ in January 1987, but was not detected in water from any other wells on the five sampling dates. Mercury was detected at five wells beneath the Belmont lagoons, but only in July 1986 and at concentrations less than the primary drinking-water regulation of $2 \mu \mathrm{g} / \mathrm{L}$ (U.S. Environmental Protection Agency, 1982a). Zinc was detected in ground water from well C2 at a concentration of $40 \mu \mathrm{g} / \mathrm{L}$ and from we11 D2 at $10 \mu \mathrm{g} / \mathrm{L}$, but only in May 1987. Z1nc was not detected in the ground water on the other sampling dates.

Organic Indicators

Simple indicators that help to detect the effect of organic constituents in sludge on ground-water quality include COD, total phenols, and MBAS. Median concentrations are listed in tables 8 and 9.

COD is an estimate of the quantity of oxygen required to oxidize organic constituents in the system (Stumm and Morgan, 1981, p. 510). COD indicates the relative degree of waste decomposition and organic contamination. High COD concentrations also are indicative of increased organic-matter content. Hem (1985, p. 158) refers to COD as a measurement "to determine pollution or oxidizable load." High statistical correlations $(r=0.98)$ have been determined between $C O D$ and metal enrichment beneath sewage-disposal ponds (Lund and others, 1976, p. 333). Median COD concentrations in the ground water beneath the Belmont lagoons ranged from $4 \mathrm{mg} / \mathrm{L}$ at we 11 D1 to $60 \mathrm{mg} / \mathrm{L}$ at we 11 B2, but no metal enrichment was found here other than dissolved iron.

Total phenols were detected in water from all the wells on at least one date during the study period. However, median concentrations were less than the detection limit, $0.005 \mathrm{mg} / \mathrm{L}$. Concentrations greater than $0.010 \mathrm{mg} / \mathrm{L}$ occurred at we1ls B2, C1, D1, D2, and E2. MBAS is a test for anionic surfactants or detergents. Any measurable concentrations of surfactants in ground water are a definite indication of a waste discharge (LeBlanc, 1984, p. 20). Commercial surfactants used before 1964 are very resistant to chemical and biological degradation and adsorb to mineral surfaces (Wayman, 1962, p. C137); therefore, these surfactants are persistent in the environment. Median concentrations of MBAS in the ground water beneath the Belmont lagoons ranged from $0.03 \mathrm{mg} / \mathrm{L}$ at we $11 \mathrm{D} 1$ to $0.35 \mathrm{mg} / \mathrm{L}$ at we $11 \mathrm{D} 2$. The secondary drinkingwater recommended limit for foaming agents, $0.5 \mathrm{mg} / \mathrm{L}$, was not exceeded (U.S. Environmental Protection Agency, 1982b). 


\section{Bacteria}

Certain bacteria commonly are used to indicate the possible presence of pathogenic viruses in wastewaters. Several authors (Romero, 1970; Vecchioli and others, 1972; Elliot and El11s, 1977; Keswick and others, 1982; Bitton and others, 1983) have used bacteria to trace ground-water flow or to indicate pollution of ground water. Water samples from wells at the Belmont sludge lagoons were analyzed for fecal collform, total collform, and fecal streptococci bacteria to indicate the effects of sewage sludge on the ground water.

The avallable data regarding survival and movement of bacteria in shallow aquifers seem to be quite variable and site specific. Vecchioli and others (1972) injected total coliform, fecal coliform, and fecal streptococci bacteria into a sand aquifer and then sampled the ground water from an observation well $20 \mathrm{ft}$ away. On1y total coliforms were detected in the we11, and they may have originated from soll bacteria. The authors determined that the movement of bacteria was restricted by the filtering efficiency of the sand and by the natural biological mat.

Although large numbers of bacteria are effectively retained or die before reaching the ground water, under favorable conditions bacteria have been known to migrate as far as $100 \mathrm{ft}$ and survive as long as 5 yr in sand and gravel aquifers (Romero, 1970, p. 211-212). Randa11 (1970, p. 719) detected fecal coliform bacteria migrating $180 \mathrm{ft}$ from the Susquehanna River to a municipal ground-water well as a result of induced infiltration through highly permeable sediments. Fecal collform bacteria have been detected moving beneath landfills at a rate of $450 \mathrm{ft} / \mathrm{d}$ over one-half mile (Keswick and others, 1982, p. 143). The bacteria were estimated to be traceable for $1.6 \mathrm{mi}$ from the source.

Results of the bacterial analyses from wells at the Belmont sludge lagoons indicate the presence of all three bacteria in ground water from some of the wells, but counts were minimal and erratic. These counts are similar to Higgins's (1984, p. 427) results beneath a land-application site for sludge. The numbers listed in tables 8 and 9 should not be considered absolute because of the interference that occurred during sampling and analysis. The numbers may reflect bacterla growing in the observation well, not in the sand and gravel aquifer.

Fecal coliform bacteria were detected only on one sampling date. Two colonies per $100 \mathrm{~mL}$ (milliliters) were detected in water from well $\mathrm{Cl}$, and 36 colonies per $100 \mathrm{~mL}$ were detected from well D2. The detection limit for coliforms varied from 2 to 20 colonies per $100 \mathrm{~mL}$, depending on the turbidity of the sample. The decay rate for fecal streptococci is less than the rate for fecal coliform or total coliform bacteria in shallow ground-water wells (Bitton and others, 1983, p. 408). Therefore, this species was expected to be present in greater numbers beneath the lagoons. Fecal streptococci were identifled in water from 8 of the 11 wells; maximum counts ranged from 1 to 46 colonies per $100 \mathrm{~mL}$. Total coliforms were detected in ground water from three shallow wells and two deep wells; maximum counts ranged from 8 to 40 colonies per $100 \mathrm{~mL}$. 
The results of the bacterial analyses indicate that although these indicator species seem to be surviving in the ground water beneath the lagoons, they are present in very small numbers, if at all. The age of the sludge, die-off of indigenous bacteria, and the filtering efficiency of the biogeological media all contribute to limiting the number of these bacteria.

\section{Changes in Ground-Water Quality With Time and Depth}

A mixed-factor ANOVA (see Methods of Investlgation) was run on the rank transformations of the data to determine whether constituent concentrations differ significantly between the five sampling dates. Fifteen constituents were excluded from this statistical analysis (specific conductance, temperature, blcarbonate, nine trace elements, nitrite, fecal coliform bacterla, and total coliform bacteria). Of the 24 constituents tested, only 7 indicate a significant difference at the 0.05 level between any of the sampling dates. Therefore, there is no seasonal change in concentration for most constituents. The seven constituents that indicated changes and their significance levels are as follows: $\mathrm{pH}(0.0134)$, DO $(0.0116)$, 1ron $(0.0156)$, organlc nitrogen $(0.0007)$, COD $(0.0062)$, phenols $(0.0002)$, and MBAS $(0.0023)$. Iron, DO, and COD concentrations were significantly higher on the first sample date (July 1986), whereas concentrations of organic nitrogen were low. Phenols generally were detected only in the October 1986 and January 1987 samples. Concentrations of MBAS also were higher in most wells on these two sample dates. No temporal pattern is apparent from a visual inspection of the $\mathrm{pH}$ data.

The paired (shallow/deep) observation wells indicate that some vertical transport of leachate occurs as a result of the hydraulic gradients and dispersion. However, the high concentrations of selected constituents in the shallow wells indicate that lateral flow is the primary mode of transport after leachate reaches the ground water. A nested ANOVA with fixed factors was run on the rank transformations to determine whether concentrations of constituents differ significantly between shallow and deep aquifers beneath the Belmont lagoons. A summary of results from the ANOVA is presented in table 10. Well $\mathrm{F}$ was omitted from this statistical analysis because there is no paired deep well at this location. Concentrations of 15 of the 24 constituents were significantly higher in the shallow aquifer; only $\mathrm{pH}$ and barlum concentrations were significantly higher in the deeper aquifer. There is no statistically significant difference at the 0.05 level between the two aquifers for concentrations of DO, magnesium, sulfate, bromide, ammonium nitrogen, phenols, and fecal streptococci bacterla. Differences in ground-water quality with depth are attributed to the absence of vertical-head differences at most of the wells, and to the presence of fine-grained silt and clay at well sites $A$ and $B$, where vertical-head differences indicate potential for downward movement of solutes. 
Table 10.--Summary of results from analysis of variance on ranks to determine differences in selected ground-water constituents between shallow and deep aquifers beneath the Belmont sludge lagoons

[p, the probability that an observed difference is due to chance rather than depth; *, marginally significant difference $(0.01 \leq p \leq 0.05)$ between shallow and deep aquifers; $* *$, highly significant difference $(p<0.01)$ between shallow and deep aquifers; ---, no significant difference]

\begin{tabular}{|c|c|c|}
\hline $\begin{array}{l}\text { Constituents } \\
\text { and properties }\end{array}$ & $\begin{array}{c}\text { Level of significance } \\
(p)\end{array}$ & $\begin{array}{l}\text { Aquifer of higher } \\
\text { concentration }\end{array}$ \\
\hline $\mathrm{pH}$ & $<0.01 * *$ & deep \\
\hline Dissolved oxygen & .77 & -- \\
\hline Calcium & $<.01 * *$ & shallow \\
\hline Magnesium & .77 & -- \\
\hline Sodium & $<.01 * *$ & sha1low \\
\hline Potassium & $.01 *$ & shallow \\
\hline Alkalinity, total as $\mathrm{CaCO}_{3}$ & $<.01 * *$ & shallow \\
\hline Sulfate & .15 & -- \\
\hline Chloride & $<.01 * *$ & shallow \\
\hline Dissolved solids & $<.01 * *$ & sha1low \\
\hline Arsenic & $<.01 * *$ & shallow \\
\hline Barlum & $<.01 * *$ & deep \\
\hline Boron 1 & $<.01 * *$ & shallow \\
\hline Bromide & .90 & -- \\
\hline Iron & $<.01 * *$ & shallow \\
\hline Manganese & $<.01 * *$ & shallow \\
\hline Nitrate, as $\mathrm{N}$ & $<.01 * *$ & shallow \\
\hline Ammonium nitrogen, as $\mathrm{N}$ & .47 & -- \\
\hline Organic nitrogen, as $\mathrm{N}^{l}$ & $<.01 * *$ & shallow \\
\hline Phosphorus, total & $<.01 * *$ & shallow \\
\hline Chemical oxygen demand & $.02 *$ & shallow \\
\hline Phenol, totall & .55 & -- \\
\hline Methylene-blue-active substance ${ }^{l}$ & $<.01 * *$ & shallow \\
\hline Fecal streptococci bacterial & .43 & -- \\
\hline
\end{tabular}

${ }^{1}$ Wilcoxon-Mann-Whitney rank sum test used for these constituents.

The greatest difference in constituent concentrations between shallow and deep wells occurs at site $B$ where the thick, low-permeability clay is present. Ground water from shallow well B2 has the highest specific conductance and concentrations of magnesium, potassium, boron, chloride, COD, and phenols (tables 8 and 9). However, water beneath the clay layer in well Bl has the lowest concentrations of iron, manganese, magnesium, calcium, bromide, and DS. In contrast to site $B$, constituents are present in high concentrations 
throughout the aquifer at site E. Water from shallow well E2 has the highest concentrations of all the wells for Iron, arsenic, and DS, and one of the highest concentrations of sulfate. These concentrations indicate moderately reducing conditions to maintain highly soluble iron and arsenic, yet not enough to reduce sulfate to sulfide. This redox environment is typical of the ground water beneath the lagoons, except at we11 C2 where nitrification is occurring. Water at well $\mathrm{E} 1$ has the highest concentrations of all deep wells for sodium, potassium, barium, alkalinity, ammonium nitrogen, organic nitrogen, and MBAS. Because site $E$ is upgradient from the lagoons except when flow reversals occur, the existing pattern of eight sludge lagoons is not a likely source for these concentrations. However, site $E$ is located near the site where old lagoons were emptied and compacted with fill material. It is possible that a slug of constituents was released from the lagoon when the lowpermeability seal was broken during excavation.

\section{QUALITY OF GROUND WATER BENEATH THE TIBBS-BANTA SLUDGE-AMENDED LANDFILL}

Leachate produced as a result of the codisposal of domestic refuse and sewage sludge in a landfill is a major concern to municipalities throughout the United States. The State of New Jersey mandated a ban on the landfill disposal of sewage sludge in 1985 in order to protect ground-water supplies (Sludge Newsletter, 1985, p. 53). The IDPW, in cooperation with the U.S. Geological Survey, funded a study in 1985 to characterize the ground-water quality beneath two closed municipal landfills where sludge had been applied (Duwelius and Greeman, in press). The results of that study will be summarized below. It is important to note that the effects of sludge on the quality of ground water could not be distinguished from the effects of the landfill refuse.

General Characteristics of Landfill Leachate

The quality of leachate, which can be produced decades after the closing of a landfill, is dependent on a number of factors that include the composition of the waste, the quantity of waste, the age of the landfill, the areal distribution of waste, the extent of infiltration, the moisture content of the waste, and the siting, design, and operation of the landfill. The USEPA (1973) reported typical landfill-leachate concentrations of $5,632 \mathrm{mg} / \mathrm{L}$ DS, 8,000 to $10,000 \mathrm{mg} / \mathrm{L}$ COD, $600 \mathrm{mg} / \mathrm{L}$ iron, and $250 \mathrm{mg} / \mathrm{L}$ chloride. These concentrations are approximately one to three orders of magnitude greater than the concentations found in the ground water beneath the Tibbs-Banta landfill. Page (1974) determined that practically all the arsenic, cadmium, chromium, copper, manganese, nickel, lead, mercury, selenium, and zinc remained in the upper $8 \mathrm{in}$. of soll $12 \mathrm{yr}$ after the application of 37 tons of sewage sludge per acre of agricultural lands. Similarly, in the ground water at TibbsBanta, concentrations of most metals and trace elements were less than detectable levels. 
Natural clays and daily cover material can be an important source of major cations in the ground water beneath landfills. In addition, carbon dioxide is produced as a result of waste decomposition. The carbon dioxide mixes with soll moisture to produce an acidic leachate that dissolves natura1ly occurring minerals, thereby increasing the hardness and DS concentrations in the leachate (Baedecker and Back, 1979b, p. 397). Detalled monitoring of sand and gravel aquifers beneath landfills indicate extensive mobility of chloride, bicarbonate, sodium, calcium, magnesium, ammonium, and iron (Baedecker and Apgar, 1984; Cherry and others, 1984; LeBlanc, 1984). Toxic inorganics typically are immobile and rarely occur in excess of USEPA drinking-water regulations and limits. Therefore, dissolved organic compounds commonly have the greatest potential to contaminate ground water beneath landfills (Cherry and others, 1984, p. 60).

\section{Water-Quality Constituents}

In their study of Tibbs-Banta landfill, Duwelius and Greeman (in press) used a suite of constituents similar to those analyzed at the Belmont sludge lagoons, but boron, MBAS, organic nitrogen, and bacteria were not included in the analysis for the landfill study. Ground-water samples were collected quarterly from May 1985 through May 1986 from a network of 18 observation wells, including the 6 used in the comparative analysis. Ammonium, bromide, chloride, potassium, sodium, and sulfate were determined to be indicators of a leachate plume at the site. Results of the analyses of ground-water quality in water from wells downgradient from the landfill are summarized in table 11 for shallow wells (I-2, J-2, and $L-2$ ) and for deep wells (I-1, J-1, and $L-1)$. For a thorough analysis of the ground-water quality at the site, see Duwellus and Greeman (in press). 


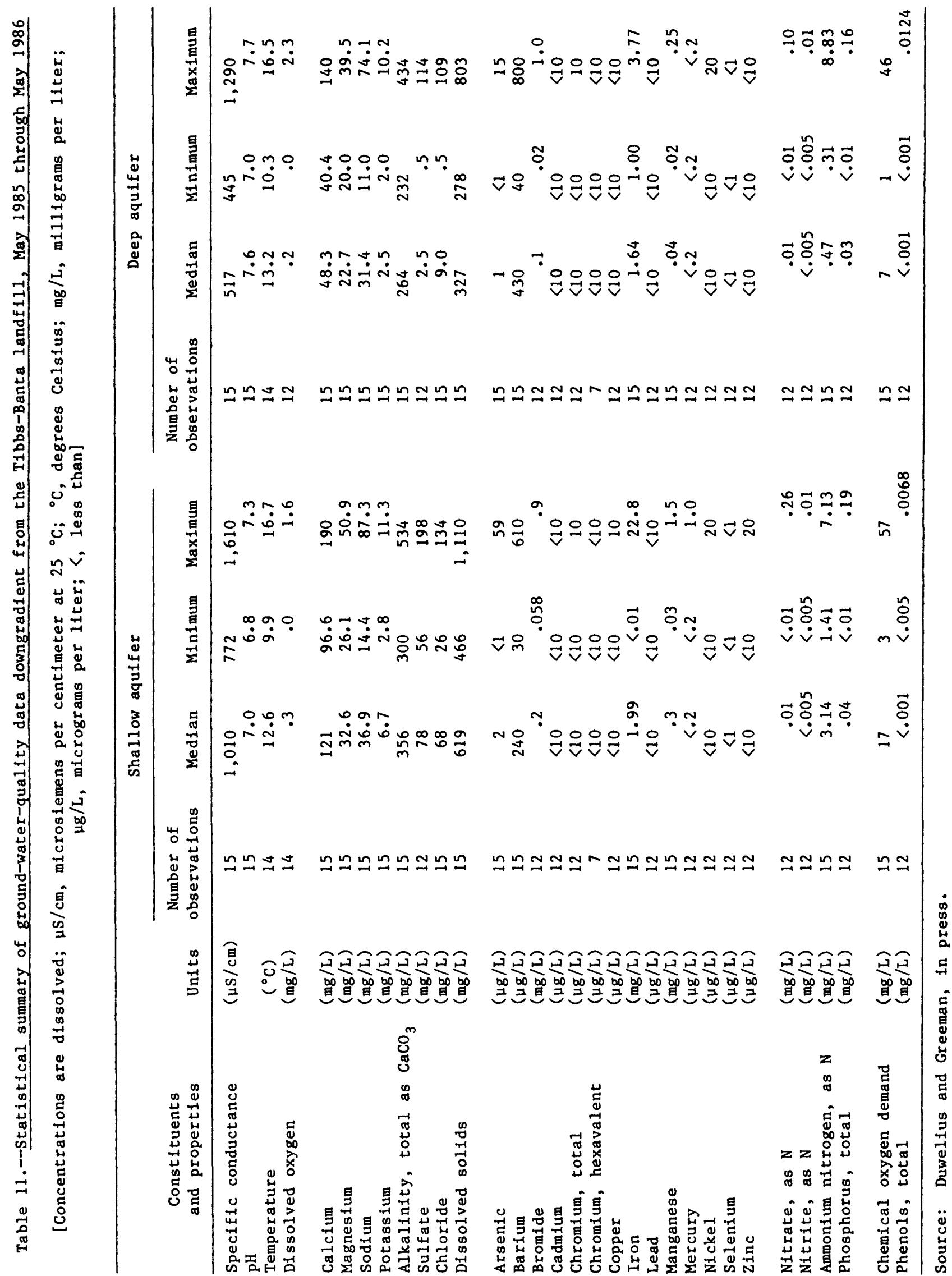


Certain constituents and properties of the ground water beneath the Tibbs-Banta landfill were measured onsite. Measurements indicated a median neutral $\mathrm{pH}$ of 7.0 in the shallow ground water, whereas the deep ground water had a median $\mathrm{pH}$ of 7.6. Specific conductance ranged from 772 to $1,610 \mu \mathrm{S} / \mathrm{cm}$ in water from the three shallow wells and from 445 to $1,290 \mu \mathrm{S} / \mathrm{cm}$ in the water from three deep wells. Nearly anaerobic conditions occurred beneath the landf111: the median DO concentration was $0.3 \mathrm{mg} / \mathrm{L}$ in the shallow ground water, and $0.2 \mathrm{mg} / \mathrm{L}$ in the deep ground water (Duwelius and Greeman, in press).

Major Ions

Ground water beneath the Tibbs-Banta landfill is characterized as a calcium bicarbonate type. Other major ions include magnesium, sodium, chloride, and sulfate. Median concentrations of chloride were $68 \mathrm{mg} / \mathrm{L}$ in shallow ground water and $9.0 \mathrm{mg} / \mathrm{L}$ in deep ground water. A possible source of sodium and chloride is the road salt applied on Tibbs Avenue during the winter months. Median sulfate concentrations were $78 \mathrm{mg} / \mathrm{L}$ in water from the shallow wells and $2.5 \mathrm{mg} / \mathrm{L}$ from the deep wells. Median concentrations of DS were $619 \mathrm{mg} / \mathrm{L}$ in the shallow ground water and $327 \mathrm{mg} / \mathrm{L}$ in the deep ground water (Duwelius and Greeman, in press).

\section{Nutrients}

Ammonium is the major nitrogen species in the ground water beneath the landfil1. Median concentration in water from the downgradient shallow wells was $3.14 \mathrm{mg} / \mathrm{L}$ and $0.47 \mathrm{mg} / \mathrm{L}$ for the deep wells. Nitrite nitrogen rarely was found in excess of the detection 1 imit of $0.005 \mathrm{mg} / \mathrm{L}$. Median concentration for nitrate nitrogen was $0.01 \mathrm{mg} / \mathrm{L}$, and the maximum concentration was $0.26 \mathrm{mg} / \mathrm{L}$ in shallow ground water at well L-2. Phosphorus concentrations were similar at all wells: median concentrations were $0.04 \mathrm{mg} / \mathrm{L}$ in the shallow ground water, and $0.03 \mathrm{mg} / \mathrm{L}$ in the deep ground water (Duwelius and Greeman, in press).

Metals and Trace Elements

Arsenic was detected in water from all six wells downgradient of the landfill at least once during the sample period, but it was detected consistently only at sha1low we11 J-2 and deep well L-1. Median concentrations of 
arsenic were $2 \mu \mathrm{g} / \mathrm{L}$ in the shallow ground water and $1 \mu \mathrm{g} / \mathrm{L}$ in the deep ground water. The maximum arsenic concentration was $59 \mu \mathrm{g} / \mathrm{L}$ at shallow well $\mathrm{J}-2$. Median concentration of barium in the shallow ground water was $240 \mu \mathrm{g} / \mathrm{L}$, compared to $430 \mu \mathrm{g} / \mathrm{L}$ in the deep ground water. Median bromide concentrations were $0.2 \mathrm{mg} / \mathrm{L}$ in water from the shallow wells and $0.1 \mathrm{mg} / \mathrm{L}$ from the deep wells. No concentrations of cadmium, hexavalent chromium, and lead ever exceeded the detection 1 imit of $10 \mu \mathrm{g} / \mathrm{L}$. Total chromium was detected only in water from we11s $\mathrm{J}-1$ and $\mathrm{L}-2$, but never in concentrations in excess of $10 \mu \mathrm{g} / \mathrm{L}$. Copper was detected only once during the study; water in well L-2 had a concentration of $10 \mu \mathrm{g} / \mathrm{L}$ copper in May 1985. Increased concentrations of iron and manganese occurred downgradient of the landfill compared to upgradient wells. Downgradient iron concentrations were $1.99 \mathrm{mg} / \mathrm{L}$ in the sha1low ground water and $1.64 \mathrm{mg} / \mathrm{L}$ in the deep ground water. The range of concentrations was much greater in water from the shallow wells; the maximum was $22.8 \mathrm{mg} / \mathrm{L}$ compared to $3.77 \mathrm{mg} / \mathrm{L}$ in the deep ground water. Median manganese concentrations were $0.3 \mathrm{mg} / \mathrm{L}$ in the shallow ground water and $0.04 \mathrm{mg} / \mathrm{L}$ in the deep ground water. Mercury was detected in excess of $0.2 \mu \mathrm{g} / \mathrm{L}$ in the August 1985 sample from shallow wells $\mathrm{I}-2$ and $\mathrm{J}-2$. Concentrations of nickel were in excess of the detection limit of $10 \mu \mathrm{g} / \mathrm{L}$ only on one sampling date in water from wel1s $\mathrm{I}-2, \mathrm{~J}-2$, and $\mathrm{J}-1$. Selenium concentrations were never in excess of the detection limit of $1 \mathrm{\mu g} / \mathrm{L}$. Zinc was detected once in ground water from well I-2 at a concentration of $20 \mu \mathrm{g} / \mathrm{L}$; otherwise zinc was never detected in excess of the detection limit of $10 \mathrm{\mu g} / \mathrm{L}$ (Duwelius and Greeman, in press).

\section{Organic Indicators}

Median concentrations of COD were $17 \mathrm{mg} / \mathrm{L}$ in shallow ground water and $7 \mathrm{mg} / \mathrm{L}$ in the deep ground water. Total phenols were detected in water from all of the wells on at least one sampling date; concentrations ranged from less than $0.005 \mu \mathrm{g} / \mathrm{L}$ to $0.0068 \mu \mathrm{g} / \mathrm{L}$ in the shallow ground water, and from less than $0.001 \mu \mathrm{g} / \mathrm{L}$ to $0.0124 \mu \mathrm{g} / \mathrm{L}$ in the deep ground water. All median concentrations of total phenols were less than the detection limit of $0.001 \mu \mathrm{g} / \mathrm{L}$ (Duwelius and Greeman, in press).

\section{COMPARISON OF GROUND-WATER QUALITY BENEATH THE BELMONT SEWAGE-SLUDGE LAGOONS}

AND THE TIBBS-BANTA SLUDGE-AMENDED LANDFILL

A nested ANOVA with fixed factors (see Methods of Investigation) was run on the rank-transformed data to determine whether ground-water quality differed significantly by aquifer between the Belmont sludge lagoons and Tibbs-Banta landf111. The aquifers (shallow and deep) were nested within location to compare shallow lagoon to shallow landfill and deep lagoon to deep landfill. Results of the analysis of variance are summarized in table 12. Well $F$ was excluded from this statistical analysis because there is no paired deep well, which is required for the nested design of the model. Constituents that are 
different at less than the 0.01 level of significance are denoted as highly significant; differences that range from 0.01 to 0.05 significance levels are denoted as marginal. The location of the higher concentration (lagoon or landfill) also is listed in the table.

Table 12.--Summary of results from analysis of variance on ranks to determine differences in selected ground-water constituents by aquifer (shallow or deep) between the Belmont sludge lagoons and the Tibbs-Banta sludge-amended landf111

[p, the probability that an observed difference is due to chance rather than location for each layer; *, marginally significant difference $(0.01<\mathrm{p}<0.05)$ between lagoons and landfill; **, highly significant difference $(\vec{p}<\overline{0} .01)$ between lagoons and landfill; ---, no significant difference]

\begin{tabular}{|c|c|c|c|c|}
\hline \multirow[b]{2}{*}{$\begin{array}{l}\text { Constituents } \\
\text { and properties }\end{array}$} & \multicolumn{2}{|c|}{ Shallow aquifer } & \multicolumn{2}{|c|}{ Deep aquifer } \\
\hline & $\begin{array}{l}\text { Level of } \\
\text { signifi- } \\
\text { cance } \\
\text { (p) }\end{array}$ & $\begin{array}{c}\text { Location of } \\
\text { higher } \\
\text { concentration }\end{array}$ & $\begin{array}{l}\text { Level of } \\
\text { signifi- } \\
\text { cance } \\
\text { (p) }\end{array}$ & $\begin{array}{c}\text { Location of } \\
\text { higher } \\
\text { concentration }\end{array}$ \\
\hline $\begin{array}{l}\mathrm{pH} \\
\text { Dissolved oxygen }\end{array}$ & $\begin{array}{l}0.13 \\
.04 *\end{array}$ & landfill & $\begin{array}{l}<0.01 * \star \\
.20\end{array}$ & landfill \\
\hline $\begin{array}{l}\text { Calcium } \\
\text { Magnesium }\end{array}$ & $\begin{array}{l}.12 \\
.23\end{array}$ & -- & $\begin{array}{l}.84 \\
<.01 * *\end{array}$ & lagoon \\
\hline Sodium & $<.01 * *$ & lagoon & .06 & -- \\
\hline Potassium & $<.01 * *$ & lagoon & $<.01 * *$ & lagoon \\
\hline $\begin{array}{l}\text { Alkalinity, total as } \mathrm{CaCO}_{3} \\
\text { Sulfate } \\
\text { Chloride }\end{array}$ & $\begin{array}{l}<.01 * * \\
.64 \\
<.01 * *\end{array}$ & $\begin{array}{l}\text { lagoon } \\
\text { lagoon }\end{array}$ & $\begin{array}{l}<.01 * * \\
.05 * \\
<.01 * *\end{array}$ & $\begin{array}{l}\text { lagoon } \\
\text { lagoon } \\
\text { lagoon }\end{array}$ \\
\hline Dissolved solids & $<.01 * *$ & lagoon & .28 & -- \\
\hline Arsenic & $<.01 * *$ & lagoon & .30 & --- \\
\hline Barium & .43 & -- & .57 & -- \\
\hline Bromide & $<.01 * *$ & landfill & .54 & -- \\
\hline Iron & $<.01 * *$ & lagoon & $.02 *$ & lagoon \\
\hline Manganese & .45 & -- & .69 & -- \\
\hline Nitrate, as $\mathrm{N}$ & $.02 *$ & lagoon & .06 & -- \\
\hline Ammonium nitrogen, as $\mathrm{N}$ & $<.01 * *$ & lagoon & $<.01 * *$ & lagoon \\
\hline Phosphorus, total & $<.01 * *$ & lagoon & .99 & -- \\
\hline Chemical oxygen demand & $.03 *$ & lagoon & .10 & --- \\
\hline
\end{tabular}


Concentrations of 13 of the 19 constituents are significantly different in the shallow aquifer at the two locations. Only DO and bromide are present in higher concentrations in the shallow aquifer beneath the landfill than beneath the sludge lagoons. The Do concentrations tend to increase when oxidizing surface water enters and flows through the many channels and other voids in the refuse. No difference in $\mathrm{pH}$ and concentrations of calcium, magnesium, sulfate, barium, and manganese were detected in the shallow aquifer between locations. Constituents present in significantly higher concentrations beneath the lagoons than beneath the landfill include sodium, potassium, alkalinity, chloride, DS, arsenic, iron, nitrate nitrogen, ammonium nitrogen, phosphorus, and COD.

In the deep aquifer, only 8 of the 19 constituents differ significantly between locations at the 0.05 level. Of these elght, only pH is higher in the ground water beneath the landfill than beneath the sludge lagoons. Concentrations of magnesium, potassium, alkalinity, sulfate, chloride, iron, and ammonium nitrogen are significantly higher beneath the sludge lagoons than beneath the landfill.

The study by Duwelius and Greeman (in press) was not designed to distinguish the effects of the sludge from the effects of the refuse on the quality of ground water beneath the Tibbs-Banta landfill, but a recent study by the USEPA (Farrell and others, 1987) simulated the effects from sludge, residential refuse, and their codisposal on leachate quality. The authors (p. 23) stated:

\footnotetext{
"***it is a popular misconception that introducing sludge into landfills degrades water quality. This study shows the reverse is true."
}

In the simulations, the addition of municipal wastewater sludge to landfill material dramatically reduced the gross organic pollution and concentration of many metals in the leachate. Ground-water contamination was controlled by the quantity as well as the quality of leachate. Although concentrations of contaminants in the sludge solids were greater than in the refuse solids, almost all the constituents of the leachate from the refuse solids initially had higher concentrations than leachate from the mixture--that is, pollutants were mobilized through the refuse, whereas pollutants were retained in the refuse-sludge mixture. The $\mathrm{pH}$ of the leachate was the controlling factor (Farrell and others, 1987, p. 2-7). The researchers determined that concentrations of COD, alkalinity, TKN, volatile acids, phosphate, and most metals from the refuse and the mixture were very similar after 4 yr (Farrell and others, 1987 , p. 23).

Apparently, the major problem with the codisposal of sludge and refuse compared with refuse only is the increased moisture content of the mixture. This increased molsture could result in greater infiltration rates of leachate to the ground water, and decreased time $1 \mathrm{ag}$ before leachate is produced. The quantity of leachate is highly correlated with the quantity of infiltration (Farrell and others, 1987, p. 7). The mechanism that ameliorates leachate quality is the rapid anaerobic biological stabilization or decomposition of carbonaceous materials that occurs much sooner when sludge is codisposed with the refuse (Lu and others, 1985, p. 166; Farrell and others, 1987, p. 22). The resulting increase in $\mathrm{pH}$ and decrease in redox potential causes cadmium, 
chromium, and lead to precipitate from solution. The 4-yr study indicated that anaerobic decomposition of refuse and sludge in laboratory test cells results in initial decreased concentrations of COD, iron, cadmlum, chromium, copper, lead, nickel, phosphorus, zinc, volatile solids, volatile acids, total organic carbon, alkalinity, and TKN, and increased $\mathrm{pH}$ and bicarbonate concentration in the leachate compared with refuse-only cells (Farrell and others, 1987 , p. 22-23).

Results of the comparison between ground water affected by Belmont sludge-lagoon leachate and ground water affected by Tibbs-banta sludge-amended landf 111 leachate can be summarized as follows: ground water beneath the sludge lagoons is characterized by significantly higher concentrations of major ions, nutrients (particularly ammonium), arsenic, iron, and COD; whereas ground water beneath the landf 111 is characterized by higher pH and higher concentrations of DO and bromide. Certain metals (cadmium, chromium, copper, lead, mercury, nickel, and $z 1 \mathrm{nc}$ ) are not found beneath either site. These results are fairly consistent with the results from previous onsite and laboratory studies (H111s, 1976; Kehew and others, 1983; Baedecker and Apgar, 1984; Lu and others, 1985; Farre11 and others, 1987).

\section{SUMMARY}

The Indianapolis Department of Pub1ic Works has stored municipal sewage sludge in lagoons at their Belmont AWT plant for approximately $30 \mathrm{yr}$. The Tibbs-Banta landfi11 is owned by the city and was closed to the public in 1974. Sewage sludge was incorporated into the surface at the landfill in 1983 and 1984. The eight sewage-sludge lagoons and the landfill overlie outwash sand and gravel deposits separated by discontinuous clay layers in the White River valley.

Five pairs of observation wells were installed through or adjacent to the levees surrounding the 40-acre Belmont sludge lagoons. Each pair included a well screened 10 to $15 \mathrm{ft}$ below the water table and another well screened deeper in the aquifer. Water levels were measured at least semimonthly from June 1986 through July 1987 in the 10 wells, in an additional well near the center of the site, and in adjacent streams.

Water-table conditions prevail in the shallow aquifer and in the full thickness of the sand and gravel aquifer where the clay layer is absent. A deeper aquifer is under confined conditions in the southwestern area of the lagoons where the clay layer separates two aquifer units. Flow of shallow ground water generally is semiradial away from the lagoons toward the white River and parallel to Eagle Creek. After an accumulation of 2 in. of precipitation during 1 week, the flow is temporarily reversed, because the White River rises much faster than the ground-water levels. Direction of flow reverses toward the lagoon center and temporary bank storage occurs unt11 the river recedes below the ground-water level. 
Ground water in the deep aquifer generally flows from the lagoon center, discharging eastward to the White River and flowing to the southwest beneath Eagle Creek. It is uncertain whether flow continues to the southwest beyond Eagle Creek or is drawn northwest toward a local industrial pumping center. Similarly to that of the shallow flow, the hydraulic gradient is reversed away from the White River after heavy rainfall. This also is a temporary phenomenon that lasts until the river level recedes below the ground-water level.

Water-table gradients beneath the lagoons are extremely sma11, averaging $0.0003 \mathrm{ft} / \mathrm{ft}$ in the shallow aquifer and $0.0006 \mathrm{ft} / \mathrm{ft}$ in the deep aquifer; however, gradients increase beneath the clay in the southwestern corner. Rates of lateral flow beneath the lagoons were estimated at 0.12 to $0.29 \mathrm{ft} / \mathrm{d}$ in the shallow aquifer and 0.10 to $0.24 \mathrm{ft} / \mathrm{d}$ in the deep aquifer. Potential for downward flow occurs at well sites $A$ and $B$, whereas a slight upward gradient occurs at site $E$.

The chemical and physical composition of the Belmont sewage sludge is quite variable. Concentrations of cadmium, chromium, copper, lead, and zinc are high compared to other municipal sewage sludge in Indiana. Yet, most characteristics of Belmont sludge generally are comparable to those found in other major cities in the United States.

Onsite water-quality measurements were taken and ground-water samples were collected quarterly from July 1986 through July 1987 at the 11 observation wells that surround the lagoons. Samples were analyzed for major lons, nutrients, metals, trace elements, organic indicators, and bacteria. Concentrations of most major ions, iron, and manganese exceed long-term concentrations for the outwash sand and gravel aquifer of Marion County.

Ground water beneath the lagoons can be characterized as having nearly neutral $\mathrm{pH}$, nearly anaerobic (except at site $\mathrm{C}$ ), and moderate to high specific conductance $(879$ to $2,560 \mu \mathrm{S} / \mathrm{cm})$. Six different water types are found beneath the lagoons. The predominant water type in the ground water is calcium bicarbonate, although ammonium nitrogen is dominant or codominant with calcium in water from three we1ls. Ammonlum is derived from organic nitrogen in the sewage sludge. The ammonium ions release other cations from exchange sites on clay minerals in the aquifer. The exchange with ammonium could be a major source of the increased dissolved solids concentrations that occur in the shallow ground water. Magnesium and sodium are prominent in the ground water from two wells at site $C$.

Ammonium was the primary form of nitrogen in water from 10 of 11 wells because of the reduced conditions in the aquifer. Only in ground water at we11 C2, which had elevated oxygen concentrations, was nitrate the dominant nitrogen species. Arsenic was detected at concentrations in excess of $50 \mu \mathrm{g} / \mathrm{L}$ in water from two wells; median concentrations were greater than the detection limit of $1 \mu \mathrm{g} / \mathrm{L}$ at all the shallow wells and at two deep wells. Concentrations of sodium, chloride, sulfate, DS, boron, iron, COD, and MBAS indicated that leachate from the sludge lagoons was reaching the shallow ground water only 2 to $5 \mathrm{ft}$ beneath the bottom of the lagoons. Concentrations of cadmium, total chromium, hexavalent chromium, copper, lead, mercury, nickel, selenium, and zinc typically were less than detection limits. These constituents are bound in the neutral, reducing environment of the sludge, or in the unsaturated zone between the lagoon bottom and the water table. Concentrations of 
total phenols also were less than detection limits on most sampling dates. Bacteria were identified in samples from many wells, but colony counts were minimal, erratic, and inconclusive.

No statistically significant differences in concentrations were found for 17 of the 24 constituents included in the statistical analysis on the five sampling dates at the Belmont sludge lagoons--that is, concentrations of most constituents do not change seasonally. Fifteen constituențs had significantly higher concentrations in the shallow aquifer compared to the deeper aquifer; only $\mathrm{pH}$ and barium concentrations were significantly higher in the deeper aquifer.

Although constituent concentrations differ areally throughout the site, the quality of shallow ground water at wells E2, F, and C2 was surprisingly similar. These are the only wells which had calcium-sodium-bicarbonate type ground water. We1ls F and C2 occur along the same ground-water flow path, whereas water from well E2 flows directly toward the White River. The water from these wells had three of the highest median concentrations for calcium, sodium, chloride, sulfate, DS, and bromide detected in the study. Water from we1ls $E 2$ and $F$ also had high concentrations of Iron and arsenic, and three of the lowest concentrations of ammonium nitrogen, COD, MBAS, and $\mathrm{pH}$. Therefore, even though distinct leachate plumes could not be mapped for the area, similar contaminant sources and processes seem to be controlling the constituents at these shallow sites near the center of the semiradial flow.

The quality of ground water beneath the Tibbs-Banta landfill is characterized as neutral to slightly alkaline, has low to moderate specific conductance, and is nearly anaerobic. The ground water is a calcium bicarbonate type with elevated concentrations of sodium and chloride, which may originate from road salt. Ammonium is the major nitrogen species. Elevated concentrations of Iron and manganese were detected beneath the landf111. Arsenic was detected in the ground water, but never at concentrations in excess of $50 \mu \mathrm{g} / \mathrm{L}$. COD concentrations were relatively low, and phenols of ten were less than detection limits. Therefore, the general characteristics of ground-water quality beneath the landfill are similar to that beneath the sludge lagoons; only the magnitude of constituent concentrations differs significantly.

The comparison of ground-water quality beneath the lagoons and the landfill involved 19 constituents common to the data sets from both locations. Statistical analysis resulted in 16 constituents with different concentrations between the two locations at the 0.05 level of significance. Concentrations of sodium, potassium, alkalinity, chloride, DS, arsenic, iron, nitrate nitrogen, ammonium nitrogen, total phosphorus, and COD are higher in the shallow aquifer beneath the sludge lagoons compared to the shallow aquifer beneath the landf111. Only concentrations of $D O$ and bromide are higher in the shallow aquifer beneath the landfill. Similarly, in the deeper aquifer, concentrations of magnesium, potassium, alkalinity, chloride, sulfate, iron, and ammonium nitrogen are higher beneath the sludge lagoons than beneath the landfil1; only $\mathrm{pH}$ is higher in the deeper aquifer beneath the landfill. 


\section{REFERENCES CITED}

Anderson, V.L., and McLean, R.A., 1974, Design of experiments: New York, Marcel Dekker, Inc., 418 p.

Baedecker, M.J., and Apgar, M.A., 1984, Hydrogeochemical studies at a landf 111 in Delaware: in Groundwater Contamination: National Academy Press, Wash., D.C., p. 127-138.

Baedecker, M.J., and Back, William, 1979a, Hydrogeological processes and chemical reactions at a landfill: Ground Water, v. 17, no. 5, p. 429-437.

- 1979b, Modern marine sediments as a natural analog to the chemically stressed environment of a landfill: Journal of Hydrology, v. 43, p. 393-414.

Baxter, J.C., and Martin, W.J., 1982, Air drying liquid anaerobically digested sludge in earthen drying basins: Journal of the Water Pollution Control Federation, v. 54, no. 1 , p. 16-26.

Bitton, Gabrie1, Farrah; S.R., Ruskin, R.H., Butner, J., and Chou, Y.J., 1983, Survival of pathogenic and indicator organisms in ground water: Ground Water, v. 21 , no. 4, p. 405-410.

Cable, L.W., Daniel, J.F., Wolf, R.J., and Tate, C.H., 1971, Water resources of the upper White River basin, east-central Indiana: U.S. Geological Survey Water-Supply Paper 1999-C, 38 p.

Chang, A.C., O1mstead, W.R., Johanson, J.B. and Yamashita, G1enn, 1974, The sealing mechanism of wastewater ponds: Journal of the Water Pollution Control Federation, v. 46, no. 1, p. 1715-1721.

Cherry, J.A., Gillham, R.W., and Barker, J.F., 1984, Contaminants in ground water: Chemical processes, in Groundwater Contamination: National Research Council, Washington, D.C., National Academy Press, p. 46-64.

Conover, W.J., 1980, Practical nonparametric statistics, 2nd edition: New York, John Wiley and Sons, $493 \mathrm{p}$.

Conover, W.J., and Iman, R.L., 1981, Rank transformations as a bridge between parametric and nonparametric statistics: The American Statistician, v. 35, no. 3 , p. 124-129.

Duwelius, R.F., and Greeman, T.K., in press, Hydrogeology, ground-water flow, and ground-water quality at two landfills, Marion County, Indiana: U.S. Geological Survey Water-Resources Investigations Report. 
Echelberger, W.F., Jeter, J.M., Glrard1, F.P., Ramey, P.M., Galen, Glenn, Skole, David, Rogers, Evan, Randolph, J.C., and Zogorsk1, John, 1979, Municipal and Industrial Wastewater sludge Inventory in Indiana: Chemical characterization of municipal wastewater sludge in Indiana, Part I: Indiana University School of Public and Environmental Affairs, Bloomington, Indiana, $109 \mathrm{p}$.

E11lot, L.F., and Ellis, J.R., 1977, Bacterial and viral pathogens associated with land application of organic wastes: Journal of Environmenta1 Quality, v. 6, no. 3, p. 245-251.

Emmerich, W.E., Lund, L.J., Page, A.L., and Chang, A.C., 1982, Movement of heavy metals in sewage sludge-treated solls: Journal of Environmental Quality, v. 11, no. 2, p. 174-178.

Farre11, J.B., Dotson, G.K., Stamm, J.W., and Walsh, J.J., 1987, The effects of municipal wastewater sludge on leachates and gas production from sludge-refuse landfills: unpublished paper presented at the U.S./U.S.S.R. Bilateral Agreement Symposium on Municipal and Industrial Wastewater Treatment, U.S. Environmental Protection Agency Water Engineering Research Laboratory, Cincinnati, Oh1o, $48 \mathrm{p}$.

Feltz, H.R., Duncan, S.S., and Zepp, Ann (eds.), 1985, 1986-87-88 Nationa1 Water Quality Laboratory Services Catalog: U.S. Geological Survey OpenFile Report 86-232, 125 p.

Furr, A.K., Lawrence, A.W., Tong, S.S., Grandolfo, M.C., Hofstader, R.A., Bache, C.A., Gutenmann, W.H., and Lisk, D.J., 1976, Multielement and chlorinated carbon analysis of municipal sludges of American cities: Environmental Science and Technology, v. 10, no. 7, p. 683-687.

Gibb, J.P., and Cartwright, Keros, 1982, Retention of zinc, cadmium, copper, and lead by geologic materials: Illinols State Water Survey Cooperative Groundwater Report 9, Champaign, Illinois, 113 p.

Glatfelter, D.R., Thompson, R.E., Jr., and Ne11, G.E., 1987, Water resources data--Indiana, Water Year 1986: U.S. Geological Survey Water Data Report IN-86-1, 441 p.

Gray, H.H., Bleuer, N.K., Hill, J.R., and Lineback, J.A., 1979, Geologic map of the $1^{\circ} \times 2^{\circ}$ Indianapolis quadrangle, Indiana and Illinois, showing bedrock and unconsolidated deposits: Indiana Geological Survey, Regional Geologic Map No. 1, 2 sheets, scale 1:250,000.

Griffin, R.A., Frost, R.R., Au, A.K., Robinson, G.D., and Shimp, N.F., 1977, Attenuation of pollutants in municlpal landfili leachate by clay minerals: Part 2-Heavy metal adsorption: Illinois State Geological Survey Environmental Geology Note no. 79,47 p. 
Harrison, Wyman, 1963, Geology of Marion County: Indiana Department of Conservation, Geologica1 Survey, Bulletin no. 28, Bloomington, Indiana, $78 \mathrm{p}$.

Hem, J.D., 1985, Study and interpretation of the chemical characteristics of natural waters (3rd ed.): U.S. Geological Survey Water-Supply Paper 2254, 264 p.

Herring, W.C., 1976, Technical atlas of the ground-water resources of Marion County, Indiana: Indiana Department of Natural Resources, Division of Water, Indianapolis, Indiana, $53 \mathrm{p}$.

Higgins, A.J., 1984, Impacts on groundwater due to land application of sewage sludge: Water Resources Bulletin, v. 20, no. 3, p. 425-434.

Hills, D.J., 1976, Infiltration characteristics from anaerobic lagoons: Journal of the Water Pollution Control Federation, v. 48, no. 4, p. 695-709.

Iman, R.L., and Conover, W.J., 1983, A modern approach to statistics: New York, John Wiley and Sons, 497 p.

Indiana Register, 1987, Land application of sludge and wastewater: Indiana Department of Environmental Management, Water Pollution Control Board, November 1987 , v. 11 , no. 2, p. 681 (327 IAC 6).

Jewe11, W.J., 1983, Sewage sludge leachate assimilation capacity, in Carberry, J.B. and Englande, A.J., eds., Sludge Characteristics and Behavior: Boston, Mass., Martinus Nijhoff Publishers, p. 396-420.

Kehew, A.E., Schwindt, F.J., and Brown, D.J., 1983, Effect of seepage from unlined municipal waste stabilization lagoons on chemical quality of groundwater in shallow aquifers: North Dakota Geological Survey Report of Investigation no. $80,146 \mathrm{p}$.

Keswick, B.H., Wang, De-Shin, and Gerba, C.P., 1982, The use of microorganisms as ground-water tracers--A review: Ground Water, v. 20, no. 2, p. $142-149$.

LeBlanc, D.R., 1984, Sewage plume in a sand and gravel aquifer, Cape Cod, Massachusetts: U.S. Geological Survey Water-Supply Paper 2218, 28 p.

Legrand, H.E., 1968, Monitoring changes in quality of groundwater: Ground Water, v. 6 , no. 3 , p. 14-18.

Lu, J.C., Eichenberger, B.A., and Stearns, R.J., 1985, Leachate from municipal landfills: New York, Noyes Publications, 453 p. 
Lund, L.J., Page, A.L., and Nelson, C.0., 1976, Movement of heavy metals below sewage disposal ponds: Journal of Environmental Quality, v. 5, no. 3, p. 330-334.

Malott, C.A., 1922, The physiography of Indiana, in Handbook of Indiana Geology: Indiana Department of Conservation, Publication no. 21, Indianapolis, Indiana, p. 67-256.

Mann, H.B., and Whitney, D.R., 1947, On a test of whether one or two random variables is stochastically larger than the other: Annals of Mathematical Statistics, v. 18, p. 50-60.

Meyer, William, Reussow, J.P., and Gillies, D.C., 1975, Availability of ground water in Marion County; Indiana: U.S. Geological Survey Open-File Report $75-312,87 \mathrm{p}$.

Montgomery, R.H., and Loftis, J.C., 1987, Applicability of the t-test for detecting trends in water-quality variables: Water Resources Bulletin, v. 23 , no. 4 , p. 653-662.

National Oceanic and Atmospheric Administration, 1986, Local climatological data, Indianapolis, Indiana: National Climatic Data Center, Asheville, North Carolina.

Page, A.L., 1974, Fate and effects of trace elements in sewage sludge when applied to agricultural lands: U.S. Environmental Protection Agency, EPA-670/2-74-005, Cincinnati, Ohio, 108 p.

Page, A.L., and Chang, A.C., 1983, Utilization of municipal wastewater and sludge on land: An overview of a 1983 workshop: Proceedings of the national conference on municipal and industrial sludge utilization and disposal, Atlantic City, New Jersey, p. 48-52.

Pettijohn, R.A., 1977, Nature and extent of ground-water quality changes resulting from solid-waste disposal, Marion County, Indiana: U.S. Geological Survey Water-Resources Investigations 77-40, 119 p.

Preul, H.C., 1968, Contaminants in groundwaters near waste stabilization ponds: Journal of Water Pollution Control Federation, v. 40, no. 4, p. 659-669.

Randa11, A.D., 1970, Movement of bacteria from a river to a municipal wel1-A case history: Journal of the American Water Works Association, v. 62, no. 11 , p. 716-720.

Reid, Quebe, Allison, Wilcox, and Associates, Inc., 1979, Facilities plan addendum for disposal of sewage sludge, Belmont general sitework project, Indianapolis advanced wastewater treatment plant: Report to Indianapolis Department of Public Works, 168 p. 
Robson, C.M., and Sommers, L.E., 1982, Spreading lagooned sewage sludge on farmland - A case history: U.S. Environmental Protection Agency Municipal Environmental Research Laboratory, Cincinnat1, Ohio, EPA-600/2-82-019, $116 \mathrm{p}$.

Robson, C.M., and Wukasch, R.F., 1980, Indianapolis considers co-disposal: Proceedings of the National Conference on Municipal and Industrial Sludge Utilization and Disposal, Washington, D.C., P. 111-114.

Romero, J.C., 1970, The movement of bacteria and viruses through porous media: Ground Water, v. 8, no. 2, p. 37-48.

Rosenthal, Robert, and Rosnow, R.L., 1985, Contrast analysis: Cambridge, Cambridge University Press, 107 p.

Russe11, G.M., Stewart, Mark, and Higer, A.L., 1987, Examples of landf111generated plumes in low-relief areas, Southeast Florida: Water Resources Bulletin, v. 23, no. 5, p. 863-866.

Ryan, B.F., Joiner, B.L., and Ryan, T.A. Jr., 1985, Minitab Handbook, 2nd Ed.: Duxbury Press, Boston, Mass., 379 p.

SAS Institute, Inc., 1985, SAS user's guide-Statistics, Version 5 edition: Cary, North Carolina, SAS Institute, Inc., 956 p.

Shampine, W.J., 1975, Water quality, in Meyer and others, Availability of ground water in Marion County, Indiana: U.S. Geological Survey Open-File Report 75-312, p. 77-83.

Sludge Newsletter, 1985, Silver Springs, Maryland, Business Publishers, Inc., v. 10, no. 7, p. 53 .

Smith, B.S., 1983, Availability of water from the outwash aquifer, Marion County, Indiana: U.S. Geological Survey Water-Resources Investigations Report 83-4144, 75 p.

Soka1, R.R., and Rohlf, F.J., 1969, Biometry: San Francisco, W.H. Freeman and Company, $776 \mathrm{p}$.

Sommers, L.E., 1977, Chemical composition of sewage sludges and analysis of their potential use as fertilizers: Journal of Environmental Quality, v. 6 , no. 2 , p. 225-232.

Sommers, L.E., Nelson, D.W., Terry, R.E., and Silviera, D.J., 1976, Nitrogen and metal contamination of natural waters from sewage sludge disposal on 1and: Purdue University Water Resources Research Center Technical Report no. 89, West Lafayette, Indiana, $103 \mathrm{p}$.

Stewart, J.A., 1983, Low-flow characteristics of Indiana streams: U.S. Geological Survey Open-File Report 82-1007, 284 p. 


\section{REFERENCES CITED--Continued}

Stumm, Werner, and Morgan, J.J., 1981, Aquatic chemistry (2nd ed.): New York, John Wiley and Sons, 780 p.

Uebler, R.L., and Swartzendruber, Dale, 1978, Flow of kaolinite and sewagesludge suspensions in sand-silt porous media: West Lafayette, Indiana, Purdue University Water Resources Research Center Technical Report no. 113.

U.S. Environmental Protection Agency, 1973, Polluted groundwater: Some causes, effects, controls, and monitoring: Washington, D.C., U.S. Environmental Protection Agency Office of Research and Development, EPA-600/4-73-001b, $119 \mathrm{p}$.

1976, Quality criteria for water, 1976: Washington, D.C., U.S. Environmental Protection Agency office of Water Planning and Standards, EPA-440/9-76-023, $501 \mathrm{p}$.

1982a, Maximum contaminant levels (subpart B of Part 141, National interim primary drinking-water regulations): U.S. Code of Federal Regulations, Title 40, parts 100 to 149, revised as of July 1, 1982, p. 315-318.

-1982b, Secondary maximum contaminant levels (section 143.3 of Part 143, National secondary drinking-water regulations): U.S. Code of Federal Regulations, Title 40, parts 100 to 149 , revised as of July 1,1982 , p. 374 .

-1986, Quality criteria for water, 1986: Washington, D.C., U.S. Environmental Protection Agency office of Water Regulations and Standards, EPA-440/5-86-001.

Vecchioli, John, Ehrlich, G.G., and Ehlke, T.A., 1972, Travel of pollutionindicator bacteria through the Magothy Aquifer, Long Island, New York, in Geological Survey Research 1972: U.S. Geological Survey Professional Paper 800-B, p. B237-B239.

Wang, Wuncheng, and Reed, Paula, 1983, Nitrobacter as an indicator of toxicity in wastewater: Illinois State Water Survey Contract Report 326, Peoria, Illinols.

Water Quality Division Committee on Nutrients in Water, 1970, Chemistry of Nitrogen and Phosphorus in Water: Journal of the American Water Works Association, February 1970, p. 127-140.

Wayman, C.H., 1962, Adsorption of anionic detergent on solid mineral surfaces: U.S. Geological Survey Professional Paper 450-C, p. C137-C139.

Wilcoxon, F., 1945, Individual comparisons by ranking methods: Biometrics, v. 1 , p. 80-83. 